\title{
UMA APRESENTAÇÃO PANORÂMICA DA FISIOGNOMIA DE UMA HISTORIOGRAFIA TERAPÊUTICA*
}

\author{
Antonio Miguel, Carlos Roberto Vianna e Júlio Faria Corrêa
}

\section{1. "Não pense, veja!" ${ }^{1}$ O ver como o olho gramatical vê}

ORGS $^{2}$ - O ver como o olho gramatical de $L W$ vê é ver como vê o olho gramatical de uma ou mais formas de vida. E não há, para ele, olho que não seja um olho gramatical. E gramática que não seja normativa, isto é, um acordo praxiológico comunitário entre humanos e não humanos que constituem e instituem interativamente modos de ver ou significar as ações dos participantes de jogos de linguagem numa forma de vida.

ORGS - Com os olhos de quais formas de vida vê o olho gramatical de LW?

$\mathbf{E V}^{3}$ - "Porque será que em diferentes épocas e em diferentes nações o mundo visivivel tem sido representado de diferentes maneiras? Será que as pinturas que hoje acreditamos como fiéis representações aparecerão tão pouco convincentes às futuras gerações como as egípcias a nós? É tudo o que diz respeito à arte inteiramente subjetivo, ou existem normas objetivas em tal matéria? Se assim é, se os métodos que hoje são ensinados na aula de desenho resultam em imitações mais fiéis da natureza que as convenções adotadas pelos egípcios, porque razão os egípcios não os adotaram? A palavra representação, quando tomada em um sentido matemático muito estrito, significa a tentativa de reproduzir "fielmente", num desenho a duas dimensões, objetos e cenas do mundo tridimensional. Esta acepção da palavra é muito limitada, até mesmo enganadora, de forma que teremos que ter em conta diversos modos de encarar a sua "fidelidade". Existem muitos tipos de representação bidimensional de objetos a três dimensões: 1) as vistas, com grande utilização no desenho industrial e na arquitetura. Neste tipo de representação, o objeto é visto segundo várias direçôes e é assim representado por vários desenhos que correspondem às diversas vistas que dele se tomam; 2) a perspectiva axonométrica, nas suas diversas modalidades e em particular a perspectiva cavaleira; 3) a perspectiva linear, cônica ou dos pintores, a mais impotante do ponto de vista histórico e matemático; 4) a geometria descritiva, ainda de amplo uso na arquitetura, é um processo de representação rigoroso, codificado pelo matemático francês Gaspar Monge nos fins do século XVIII".

$\mathbf{L W}^{4}$ - Uma das fontes principais da nossa falta de compreensão é que não temos uma visão sinóptica do uso das nossas palavras. - Nossa gramática carece de visibilidade panorâmica. - A

\footnotetext{
* DOI - 10.29388/978-65-86678-51-2-0-f.15-106

1 Aforismo de Wittgenstein (LW, IF-66) que caracteriza metonimicamente o seu modo (auto)terapêutico de filosofar.

2 Abreviação que, ao longo deste texto, referencia as vistas ou os pontos de vista dos organizadores desta obra. LW, inclusive no corpo do texto, referencia pontos de vista de Ludwig Wittgenstein. As demais siglas são as iniciais de nomes e sobrenomes dos demais autores, usadas para referencias os seus respectivos pontos de vista.

${ }^{3}$ Composição condensada de trechos da referência (VELOSO, 2000, p. 135-136, grifo nosso).

${ }^{4}$ (LW, IF-122, grifo nosso).
} 
apresentação panorâmica (übersichtliche Darstellung) facilita a compreensão, que consiste precisamente em 'ver conexões'. Daí a importância de encontrar e inventar os elos intermediários. O conceito de apresentação panorâmica é para nós de importância fundamental. Ele designa a nossa forma de apresentação, o modo como nós vemos as coisas. (Isto é uma 'visão de mundo'?).

NP $^{5}$ - A dificuldade de traduzir übersicbtliche Darstellung tem sido frequentemente observada, mas, geralmente, é a tradução de übersichtliche que é questionada. No entanto, a meu ver, a tradução de Anscombe da palavra Darstellung como "representação" é extremamente infeliz. Apesar de "representação" ser geralmente uma tradução perfeitamente aceitável de Darstellung, no caso de LW, não é. Em minha opinião, na passagem IF-1226, ela deveria ser traduzida por "apresentação", pois esta palavra se ajusta muito melhor à insistência de LW em descrever os fatos como eles se apresentam, sem "re-apresentálos" em uma teoria supostamente explicativa. Como diz LW em IF-220: "Sem sentido. Sem sentido, porque você está fazendo suposições em vez de simplesmente descrever. Se a sua cabeça é assombrada por explicações, aqui, você está negligenciando a lembrar-se dos fatos mais importantes". Minhas objeções ao uso da palavra "representação" neste contexto são, em primeiro lugar, porque essa palavra sugere uma imagem que é relativamente fixa, uma "imagem" no sentido de LW, que supostamente retrataria a "essência" de um fenômeno. Em segundo lugar, a palavra "representação", nesse contexto, é demasiado "carregada de teoria", o que, obviamente, entra em conflito com o método de LW de 'desconstruir' representacõoes teóricas. LW não quer dizer ou significar por Übersichtliche Darstellung algum método especial ou perspectiva (uma espécie de rede "para descrever a realidade") que revela "a forma como as coisas realmente são". É simplesmente uma advertência para descrever ("apresentar") os fatos relevantes de tal forma a 'lembrar-nos' do que nós já sabemos (mas que "esquecemos" sob o encalço da teoria filosófica), sem re-apresentação (e, assim, distorcendo ou falsificando) deles por alguma teoria filosófica preconcebida.

ORGS - Em sua tradução recente para o português das Investigações filosóficas, o professor João J. R. L. Almeida apresenta uma longa nota à passagem IF-122 $2^{7}$, a fim de esclarecernos acerca dos significados correntemente associados ao conceito de übersichtliche Darstellung - por ele traduzido por "apresentação panorâmica" - por parte de alguns tradutores e comentadores da obra de LW. Nesta nota, outras traduções de tal conceito são: representação perspicua, clara ou nítida para "perspicuous representation", proposta por Anscombe; visão a partir do olho de um pássaro para "bird's eye view”, proposta por Hargreaves \& White; visão sinóptica para "synoptic view” de certos fatos, proposta pelo próprio LW, em suas aulas e manuscritos, como um método de remoção das dificuldades que se manifestam na investigação terapêutica de um problema; representação investigável, pesquisável ou vistoriável para "surveyable representation", proposta por Hacker \& Schulte; representação panorâmica, proposta Bruni; "exposição de conjunto", proposta por Montagnoli. Almeida opta por traduzir a übersichtliche Darstellung de LW por "apresentação panorâmica", sobretudo para se evitar a disseminação de "conotações representacionistas e cognitivistas" ou, mais amplamente, diríamos nós, conotações psicológicas vistas como inadequadas do conceito e do método de

5 (PLEASANTS, 1999, p. 14-15, grifo nosso).

${ }^{6}$ Usaremos IF, daqui em diante, para nos referimos à obra Investigações Filosóficas de LW.

7 (ALMEIDA in LW, s/d, Nota 62, p. 321-323). 
investigação por ele instaurado. Almeida ${ }^{8}$ acusa o que denomina de uma virada metodológica no uso que LW passa a fazer do conceito de "apresentação panorâmica": se até o final da década de 1920, LW ainda acreditava ser possível constituir uma linguagem fenomenológica isto é, uma linguagem das sensações cujos signos fossem constituídos exclusivamente por dados ou estímulos diretamente significados pelos sentidos, independentemente das regras de uma gramática que orientassem um tal processo de significação -, a partir do contexto da discussão da obra de Frazer $^{9}$ esta crença é abandonada e reelaborada não só com base no debate que LW estabelece com essa obra, mas também com as obras de Goethe, Darwin, Spengler, Freud e Weininger. No contexto desses debates, o conceito de apresentação panorâmica teria passado a vincular-se ao conceito de "fisiognomia", visto como o processo de ver a mesma imagem sob diferentes perspectivas. Neste ver de outra forma $\mathrm{o}$ conceito-chave constitutivo do método terapêutico-gramatical, o octaedro de cores surge, neste momento, como um exemplo do conceito de "apresentação panorâmica", isto é, como um exemplo da imagem das regras constitutivas de sua própria gramática e, portanto, das regras orientadoras dos usos desse conceito.

ORGS - O octaedro de cores de $\mathrm{LW}^{10}:$ Não pense, veja?

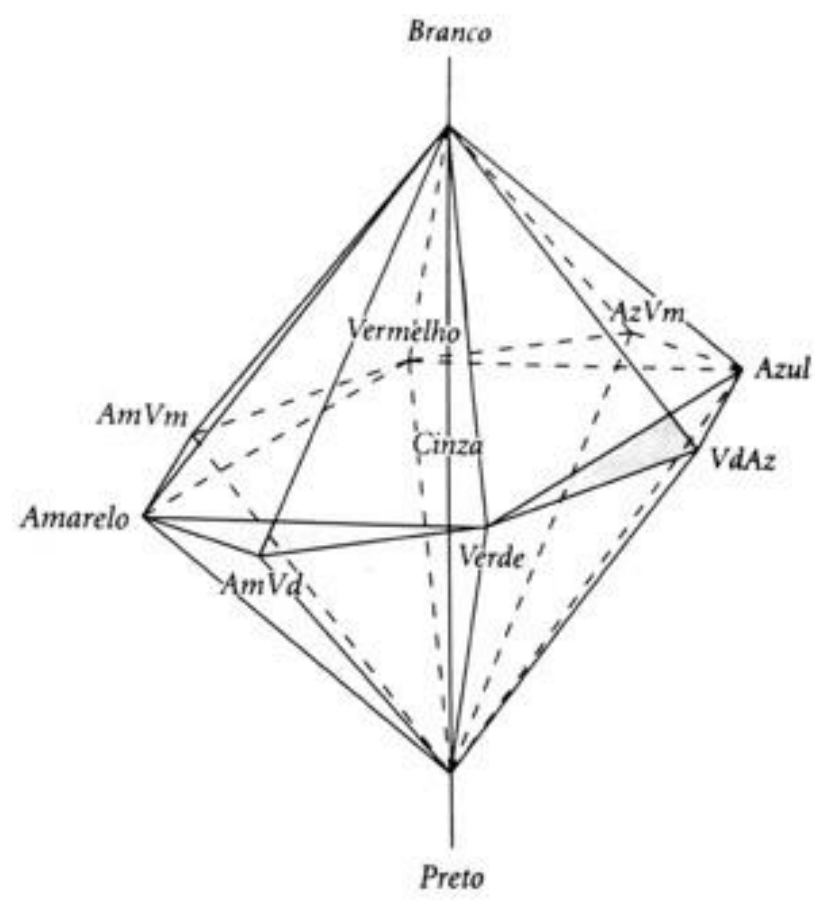

LW - "O octaedro das cores é gramática, já que diz que se pode falar de um azul avermelhado, mas não de um verde avermelhado etc." ${ }^{11}$

\footnotetext{
8 (ALMEIDA in LW, s/d, Nota 62, p. 321-323).

${ }_{9}$ Trata-se da obra monumental em 13 volumes intitulada The Golden Bough (FRAZER, 1936/1966), traduzida para o português sob o título O ramo de ouro (FRAZER, 1982) do antropólogo escocês James George Frazer (1854-1941). Já o conjunto de observações críticas que LW a ela remete foram postumamente publicadas e traduzidas para o português sob o título "Observações sobre o Ramo de Ouro de Frazere" (LW, 2007). Miguel \& Tamayo (2020) sugerem que tal obra constitui o marco decolonial emblemático de partida da crítica terapêutico-gramatical que LW dirige à obra de Frazer.

${ }^{10}$ Imagem extraída de (GUERRA, 2016, p. 72).

11 (LW, 2005, \$39).
} 
LW - "Caso alguém deseje imaginar um laranja azulado, um verde avermelhado, ou um violeta amarelado, sentir-se-ia como em um vento norte vindo do sudoeste... branco e preto são ambos não transparentes ou corpóreos... água branca e turva é tão inimaginável quanto o leite cristalino"12.

$\mathbf{M G}^{13}$ - "Newton, ao contrário de Goethe e Schopenhauer, preocupou-se somente em estabelecer os critérios para a produção da cor como fenômeno físico. Nesse aspecto, embora as críticas de Goethe se revelassem posteriormente inconsequentes, o principal mérito de sua análise é ter mostrado que a cor também existe como fenômeno que escapa à física. Assim, essas duas interpretações diversas do fenômeno cromático não devem ser pensadas como necessariamente incompatíveis, mas como pontos de vista que se baseiam em critérios, ou métodos de comparação inteiramente distintos. [...] $\mathrm{Na}$ verdade, o que estava por trás dessa dissensão era o confronto de dois modos completamente distintos de pensar a natureza. O idealismo alemão recusa a ótica mecanicista, já que interpreta tanto a natureza quanto a arte a partir da ideia de organismo, de uma finalidade interna. [...] Segundo Elie, do ponto de vista do sentido visual, luz e cores são fenômenos de consciência (sensações, percepções) cujas condições são ocorrências fisiológicas na retina e no sistema nervoso, sendo provocadas por sua vez por processos físicos. [...] Goethe propõe uma interpretação das cores a partir do órgão da visão, que não pode ser identificado a um conjunto de prismas e lentes, pois o olho é um órgão vivo. Sua aversão a experimentos com lentes e prismas, no interior de um quarto escuro, ilustra bem essa nova postura diante do fenômeno cromático. A investigação ao ar livre, onde o olhar reencontra a natureza, é a única que parece fasciná-lo".

JS - "Finalmente, portanto, fenomenologia é gramática. Por isso mesmo, com esse novo e intenso sentido, LW pode preferir a expressão do espaço das cores por meio do octaedro, opondo-se à diluição do duplo cone, menos apto a expressar a assimetria dos pontos excelsos em seu equador. Prefere assim, no equador, o quadrado ao círculo. O modelo do octaedro pode configurar a unidade da experiência perceptiva em um sentido mais profundo. Não ajuda a prever o resultado de algum experimento, não diæo o que provavelmente veremos ou o que deve ser agradável ver, mas antes o limite do que podemos reconhecer como visivel. A razão da preferência é gramatical, para marcar a diferença entre ser uma mistura de duas cores (próprio da expressão de pigmentos) e estar entre duas cores (próprio das possibilidades gramaticais).Trata-se de preferir o modelo que deixa ver melhor o aspecto essencial, envolvendo inclusive relações assimétricas e passagens interditadas. LW explora então essa natureza gramatical, através da qual o octaedro passa a cifrar a possibilidade de enunciados significativos sobre a cor, sendo artifício apenas como seria um artifício a geometria euclidiana, que, de resto, também é parte da gramática"14.

ORGS - "Misturar duas cores" com o propósito de se pintar um quadro - uma prática ou atividade praxiológica de misturar tintas produzidas por pigmentos coloridos que se realiza

\footnotetext{
12 (LW, 2009b, I, \21, p. 33).

13 Ponto de vista de Marco Giannotti extraído da apresentação que faz em sua tradução para o português do livro Doutrina das cores de Goethe (GOETHE, 1993, p. 18-20, grifo nosso).

14 (SALLES, 2012, p. 128-129, grifo nosso).
} 
na forma de vida das artes visuais -, assim como "estar entre duas cores" no octaedro de cores de LW - uma prática de representação grafovisual que se realiza na forma de vida da comunicação simbólica -, não é também uma "possibilidade gramatical"? O que seria então "o limite do que podemos reconhecer como visível", senão o limite do que podemos reconhecer como visível, com base em diferentes gramáticas normativas do visível acordadas na forma de vida da comunicação simbólica?

LW - "Quando construi uma linguagem usando um sistema de coordenadas para representar um estado de coisas no espaç, introduzi na linguagem um elemento que ela normalmente não usa. Esse recurso é certamente permissível. E mostra a conexão entre a linguagem e a realidade. O signo escrito sem o sistema de coordenadas não tem sentido. Não devemos, então, usar algo semelhante para representar as cores?"15

JS - "LW, uma primeira vez em 06 de fevereiro de 1929, recorre ao octaedro das cores modelo que já lhe serve então para ensinar diferenças, mas em um sentido preciso. $\mathrm{O}$ octaedro localiza a cor, expressando uma espécie de interdição múltipla, mas não da forma que o fará ao tempo das Anotações sobre as Cores $^{16}$ ou mesmo logo em seguida, no período intermediário. Nessa primeira referência ao octaedro, afirma-se antes que cada ponto de sua superfície representa uma cor, mostrando-se, por exemplo, um violeta claro mais próximo do vermelho que do azul.Trata-se então de uma distância espacial, passível de expressão por um número, de sorte que teriam a mesma multiplicidade lógica o modelo, o sistema de números racionais e o espaço visual a ser representado. O fundamental então é essa superfície expressar uma relação expansível, da mesma natureza lógica do que pretende representar" ${ }^{\prime 17}$.

ORGS - O que poderia significar a "natureza lógica" de uma "forma de expressão", senão um acordo praxiológico-gramatical na forma de vida da comunicaşão simbólica?

ORGS - “Onde acaba a percepção visual e onde começa o raciocínio?” É esta a pergunta que o professor Eduardo Veloso se faz no capítulo intitulado Visualização e Representação de seu livro Geometria: temas actuais: materiais para professores, após ter proposto aos seus leitores uma atividade pedagógica introdutória para se investigar a seguinte questão: "Quando olhamos para esta figura, o que vemos?”

\footnotetext{
15 (LW, 2005, §46, grifo nosso).

16 (LW, 2009b).

17 (SALLES, 2012, p. 126-127, grifo nosso).
} 


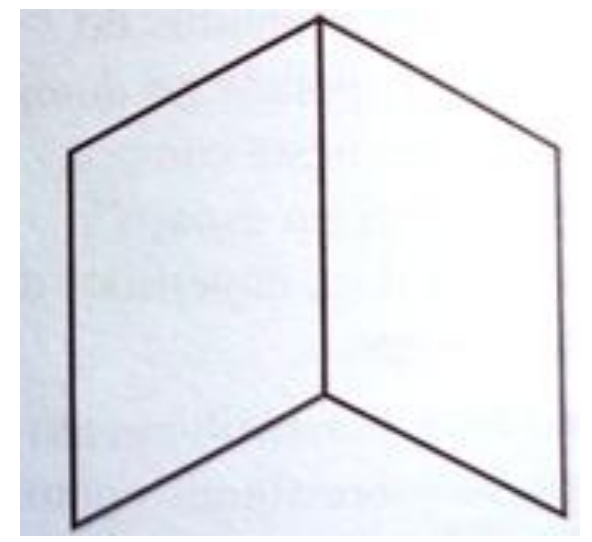

E continua: "Muitos dirão que se trata de qualquer coisa como um livro aberto, recusandose a aceitar que estão a ver apenas dois paralelogramos iguais unidos por um dos lados maiores" $"$. Veloso conclui assim a investigação proposta aos leitores: "No decorrer da resolução da atividade, aquilo que nos habituamos a chamar visualização - sem nos preocuparmos de momento com a definição precisa - teve um papel fundamental. Foi ela que ajudou a formar na nossa mente uma imagem tridimensional da stella octangula, a partir dos dois tetraedros inscritos no cubo inicial. Depois, foi difícil distinguir, nos raciocínios subsequentes, o que se poderia considerar "lógica pura", sem apoio a imagens, do que estava simplesmente baseado na intuição visual e apoiado em representações de imagens mentais que íamos construindo. Mesmo sem considerar o papel da manipulação de modelos, o que esteve em jogo ao longo desta atividade foi essencialmente uma atividade intelectual complexa, na qual é impossivel distinguir onde acaba a percepsão visual e comeşa o raciocínio. Um esquema simplista, em que primeiro nos apercebemos da situação (neste caso através da visão e também da manipulação) e depois pensamos e raciocinamos sem mais recorrer a imagens, parece-nos completamente desajustado neste caso. E no entanto, como vimos no início deste capítulo, a visão atraiçoa-nos, levando-nos por exemplo a ver triângulos onde não existem. Isso quer dizer que, desta forma, ao não distinguir escrupulosamente entre percepção e pensamento, estamos a introduz̧ir nas nossas argumentações e demonstrações elementos perturbadores, que podem suscitar dúvidas sobre o rigor das nossas conclusões. Que fazer?’19.

ORGS - Não seria tão ou mais pertubardor imaginar que poderíamos distinguir escrupulosamente entre percepção e pensamento, quando se tem em vista que pensar é ver como?

ORGS - Neste exemplo de perspectiva cônica que nos dá a ver a imagem seguinte ${ }^{20}$, o quadrilátero A'B'C'D' é o desenho que veria e pintaria em sua tela (o plano beta) um pintor cujo olho, situado no ponto $\mathrm{O}$ (o ponto de vista), olhasse para o quadrilátero $\mathrm{ABCD}$ (situado no plano alfa) com o propósito de desenhá-lo em sua tela. Como se pode ver, embora o quadrilátero ABCD - situado bem abaixo da linha do horizonte (h) constituída pelo

18 (VELOSO, 2000, p. 119).

19 (VELOSO, 2000, p. 119-125, grifo nosso).

${ }^{20}$ Figura extraída de (VELOSO, 2000, p. 146). 
ponto de vista do pintor - possua, na realidade, dois pares de lados paralelos, o seu desenho em perspectiva cônica (o quadrilátero $A^{\prime} B^{\prime} C^{\prime} D^{\prime}$ '), relativamente ao ponto de vista $\mathrm{O}$, só possui um par de lados paralelos. Imaginem agora que o olho do pintor se afastasse, na mesma direção (AO) em que se encontra, e se colocasse imaginariamente "no infinito". Sob esta nova perspectiva, as linhas $\mathrm{AO}, \mathrm{BO}, \mathrm{CO}$ e $\mathrm{DO}$ que ligam os vértices do quadrilátero $\mathrm{ABCD}$ ao olho do pintor seriam paralelas entre si, e o novo quadrilátero A'B'C'D'que ele desenharia na sua tela (o plano beta) seria uma representação em perspectiva cavaleira do quadrilátero $\mathrm{ABCD}$.

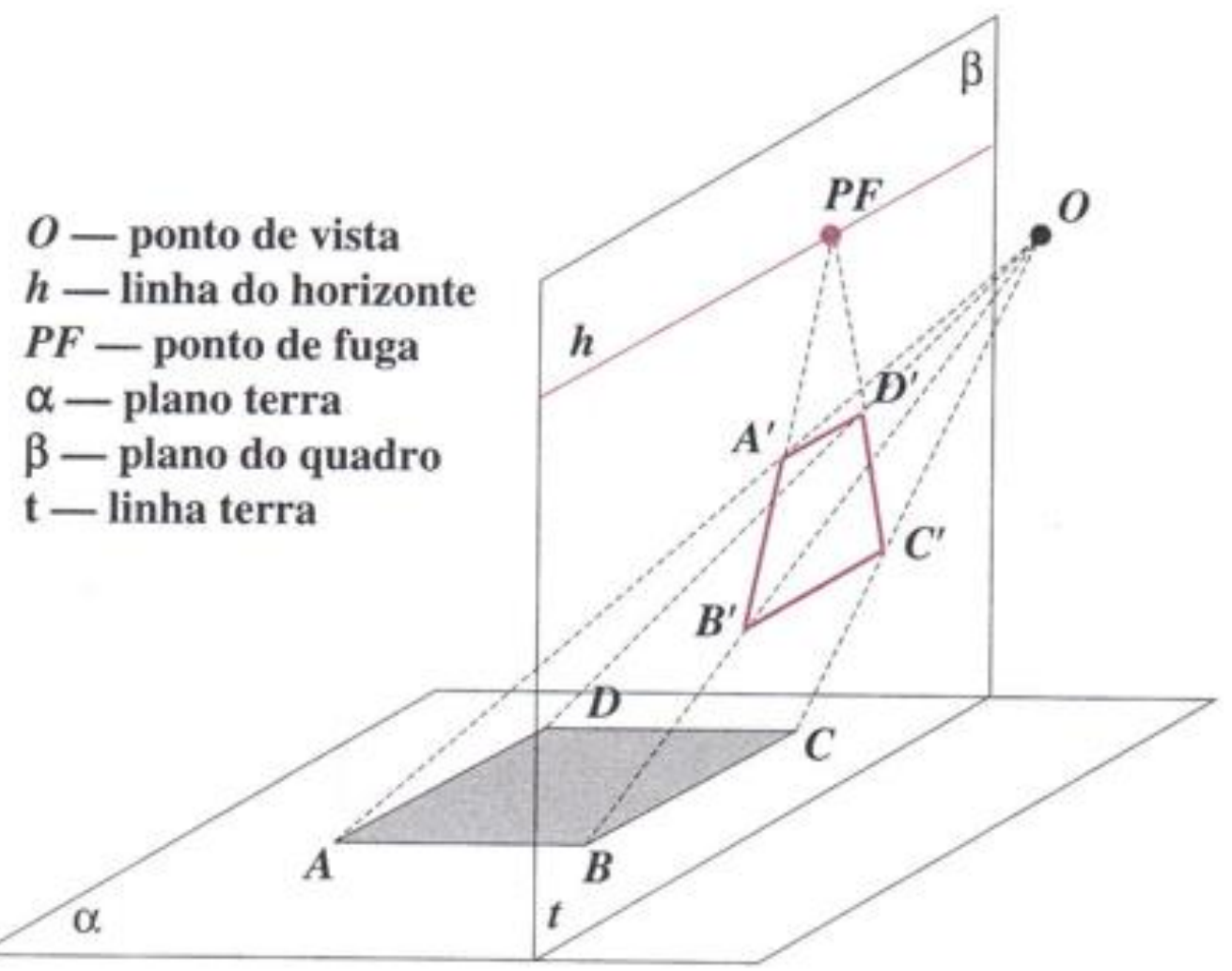

ORGS - Para se destacar a característica gramatical do método de investigação que o conceito de "apresentação panorâmica" promove e nomeia após a virada metodológica no uso que LW passa a fazer desse conceito, propomos vê-lo como um método que opera sobre a gramática de um ou mais jogos de linguagem dos quais o problema que aqui estamos levando ao divã terapêutico wittgensteiniano - qual seja, o da fisiognomia de investigações historiográficas vistas como terapêuticas - participa com significações e tratamentos diversos. Estamos mobilizando aqui a expressão gramática de um jogo de linguagem sobretudo para nos referirmos ao conjunto de regras ou condicionamentos não prescritivos que orientam significativamente as inter(ações) dos corpos de seres humanos ou não que participam direta ou indiretamente do jogo. Dizemos ainda que um jogo de linguagem é orientado por uma gramática, mesmo no caso em que ele esteja sendo jogado de um modo não gramatical, isto é, sem que um ou mais participantes do jogo estejam cientemente seguindo 
as suas regras. Já quando um jogo de linguagem estiver sendo jogado sem a orientação de uma gramática ou conjunto de regras, diremos ser ele um jogo agramatical ou sem sentido. Mas quando usamos o adjetivo gramatical para caracterizar o método de investigação que o conceito de "apresentação panorâmica" promove e nomeia, estamos nos referindo também às conexões adequadas que estabelecemos entre as regras do jogo de modo a dar visibilidade panorâmica à sua fisiognomia e, portanto, à adequação da conexão no sentido de seu poderperformativo de dar a ver a imagem que assume o problema no interior do jogo no qual ele se constitui como um problema.

ORGS - Para Almeida, a ressignificação do conceito de "apresentação panorâmica" por LW, após a sua virada metodológica, preserva “[...] além de todas as nuances do método gramatical, mais coerentista, os aspectos dinâmicos de uma fisiognomia do texto ou de uma geografia conceitual, que solicitam claramente o emprego da visão, da imaginação e da comparação na atividade investigativa" ${ }^{21}$. Por essa razão - distanciando-se de uma conotação detetivesca do conceito sugerida pela tradução de Hacker \& Schulte -, Almeida vê uma investigação terapeuticamente orientada pelo conceito ressignificado como "[...] um ato estético em que recursos visuais tentam chamar a atenção do espectador para algo de mais difícil percepção, como se LW fosse um esteta da persuasão" 22 . Independentemente dos modos como seus tradutores ou comentadores traduzem, nomeiam e significam, diversamente, o método terapêutico wittgensteiniano de investigação de um problema, dado ser o próprio LW que insiste em dar-nos a vê-lo como um método que visa fornecer uma apresentação panorâmica de conexões analógicas adequadas, nem causais e nem casuais, nem racionais e nem irracionais, entre diferentes modos como um problema é significado à luz de diferentes gramáticas - vistas como padrões normativos que condicionam possibilitando ou impedindo as inter(ações) no jogo -, o problema particular devidamente reconsiderado que estamos aqui levando ao divã terapêutico passa a ser visto como o da constituição da fisiognomia de uma übersichtliche Darstellung em investigações terapêutico-historiográficas. Ou, mais propriamente, como uma investigação das fisiognomias das gramáticas de investigações filiadas ao paradigma morfológico, com o propósito de se dar visibilidade às semelhanças e dessemelhanças de tais gramáticas em relação à fisiognomia da gramática de uma investigação historiográfica terapeuticamente orientada pelo conceito wittgensteiniano de "apresentação panorâmica".

ORGS - LW não significa os seus conceitos mediante definições analíticas, mas sim, mediante definições ostensivas, isto é, apresentando exemplos, geralmente um objeto ou uma imagem, apontando-se o dedo para ele e enunciando: - isto é um.... Assim, enunciar uma definição ostensiva ou de qualquer outra natureza é estabelecer uma norma que indica um modo de significar o objeto apontado, dentre outros possiveis, mas não quaisquer. Não é surpreendente, portanto, que LW tenha apresentado o seu conceito de apresentação panorâmica apontando o seu dedo para a imagem de um octaedro de cores: Não pense, veja!

ORGS - "Não mais se colocará então o operar com sinais escritos - e sonoros - como contrário ao operar com "imagens de representação" dos acontecimentos. Nós temos que

\footnotetext{
21 (ALMEIDA in LW, s/d, Nota 62, p. 321-323, grifo nosso).
}

22 (ALMEIDA in LW, s/d, Nota 62, p. 321-323, grifo nosso). 
arar toda a extensão da linguagem" ${ }^{\prime 23}$. Em notas ${ }^{24}$ a esta passagem das Observações sobre o Ramo Dourado de Frazer, Almeida esclarece: "No Tractatus Logico-Philosophicus, LW concebia que a linguagem era um traje que disfarçava o pensamento ${ }^{25}$, sobre a ideia do "pensar" como atividade essencialmente ligada a signos. A atividade de pensar, no Tractatus, é essencialmente lógica. Se não há muita lógica na linguagem natural, a função do filósofo é esclarecer o que há de lógico disfarçado pela vestimenta da linguagem. Agora, no entanto, o operar com sinais escritos e sonoros, isto é, no senso estrito do verdadeiro ou falso, não é mais oposto a qualquer outra forma de pensar, daquelas formas de pensar que não têm necessariamente a forma da proposição bipolar. Linguagem e pensamento não mais se separam. Há portanto uma imensa extensão da linguagem que deve ser arada, já que não mais se restringe ao verdadeiro ou falso". Em ambos os casos - pensamos nós - o ato de pensar não pode mais ser visto nem como uma atividade psicológico-mental-cognitiva ou mesmo exclusivamente cerebral - o que já não o era para o LW do Tractatus - e nem como uma atividade exclusivamente linguístico-lógico-proposicional, como o era para o LW do Tractatus, mas sim como uma atividade praxiológico-corporal integral que passa a ser vista como apenas uma modalidade, dentre outras, de se lidar corporalmente com signos, no caso, de se lidar com os sinais inscritiveis de várias modalidades de linguagem - como, por exemplo, as da lógica, da matemática e as de todas as linguagens nativas escritas - e de se lidar com os sinais sonoros de várias modalidades de linguagem como, por exemplo, as da música e as de todas as linguagens orais nativas. $\mathrm{O}$ ato de pensar passa a ser visto como uma atividade praxiológico-gramatical como outra qualquer, isto é, como um agir corporal sobre os signos de qualquer natureza de um jogo de linguagem. E gramática vista não só como um conjunto de regras de usos do corpo, orientadoras e significadoras das ações corporais - e o uso de uma palavra num jogo falado ou escrito de linguagem de uma língua nativa qualquer passa também a ser visto como uma atividade corporal como outra qualquer -, mas também, como conjunto de regras que mostra as conexões legítimas ou ilegítimas, compatíveis ou incompatíveis, significativas ou sem sentido entre esses diferentes usos, e que pode, enfim, apresentar, dar visibilidade, em perspectiva panorâmica, cavaleira, às diferentes fisiognomias que assumem essas conexões.

$\mathbf{B R}^{26}$ - "Eu tive uma segunda visita de LW, mas esta só durou 36 horas, e não foi suficiente de forma alguma para ele me dar uma sinopse de tudo que ele tem feito. Ele me deixou uma quantidade grande de papeis datilografados. [...] Ele usa as palavras "espaço" e "gramática" em sentidos peculiares, que estão mais ou menos conectados um com o outro. Ele afirma que se é significativo dizer "isto é vermelho", não pode ser significativo dizer "isto é barulhento". Há um "espaço" de cores e outro "espaço" de sons. Estes espaços são aparentemente dados a priori no sentido kantiano ou talvez não exatamente assim, contudo, algo não tão diferente. Erros de gramática resultam da confusão de "espaços". [...] Suas teorias são certamente importantes e muito originais. Se elas são verdadeiras, eu não sei. Eu devotamente espero que não, porque elas fazem da matemática e da lógica quase inacreditavelmente difíceis. Alguém tem que definir um "espaço", como ele usa a palavra,

\footnotetext{
23 (LW, 2007, p. 199).

${ }_{24}$ Tratam-se das notas 74 e 75 acessíveis em (LW, 2007, p. 221).

25 (LW, TLP, \4 4.002).

${ }^{26}$ Bertrand Russell em carta a Moore, de 5 de maio de 1930 (apud SILVA, 2011, p. 229).
} 
como um conjunto completo de possibilidades de um dado tipo. Se você diz "isto é azul", existe um número de outras coisas que você pode dizer significativamente, a saber, todas as outras cores".

CR - What is pink? A rose is pink

By the fountain's brink.

What is red? A poppy's red

In its barley bed.

What is blue? The sky is blue

Where the clouds float through.

What is white? A swan is white

Sailing in the light.

What is yellow? Pears are yellow

Rich and ripe and mellow.

What is green? The grass is green,

With small flowers between.

What is violet? Clouds are violet

In the summer twilight.

What is orange? Why, an orange,

Just an orange! ${ }^{27}$

$\mathbf{D J}^{28}$ - "Os olhos são testemunhas mais seguras do que os ouvidos, diz Heráclito. Embora não haja cores nos fragmentos que nos restam de sua obra".

ORGS - Nas Investigações filosóficas, o aforismo Não pense, veja! - que orienta LW em sua investigação terapêutico-gramatical de um problema visando ao seu esclarecimento ou desconstrução, com base na constituição de uma apresentação panorâmica das gramáticas que o significam em diferentes jogos de linguagem - só pode não contradizer a sua crença de que um problema não pode ser de modo algum significado independentemente de uma gramática que oriente a significação, caso os jogos de linguagem do ver e, mais precisamente, do ver como, não sejam vistos como opondo-se aos jogos de linguagem do pensar. E a condição para que não os vejamos como opondo-se entre si - os primeiros tendo, supostamente, o poder de significar exclusivamente mediante percepção sensorial pura e direta e os últimos exclusivamente mediante normas convencionais supostamente independentes da experiência praxiológico-perceptiva - é a de ver o poder de significar de ambos como dependente, sim, da experiência praxiológico-perceptiva. Porém, esta última é impotente para significar, por si só, independentemente das regras gramaticais acordadas entre os

\footnotetext{
27 Poema para cantar/ recitar de Christina Georgina Rossetti intitulado O que é cor de rosa? Em uma tradução livre que intencionalmente não preserva justamente o que ele mais nos dá a ver e ouvir - o contraste entre a sonoridade das rimas, da melodia dos versos e do mundo sonoro que só o ouvido e a recitação do poema em linguagem oral acusa e o colorido das cores do mundo visual que só o olho e o significado das palavras na linguagem escrita acusa -, o poema, em sua sonoridade desconstruida, pode ser lido/visto assim: "O que é cor de rosa? / Uma rosa é rosa perto da fonte / O que é vermelho? Uma papoula é vermelha / em seu leito de cevada. O que é azul? / O céu é azul onde as nuvens flutuam. / O que é branco? / Um cisne é branco / navegando na luz. / O que é amarelo? As peras são amarelas / e maduras e doces e nutritivas. / O que é verde? A grama é verde / com pequenas flores nela./ O que é violeta? As nuvens são violetas / no crepúsculo de verão. / O que é laranja? Ora, uma laranja / apenas uma laranja!” (apud JARMAN, 2010, p. 7).

28 (JARMAN, 2010, p. 3, grifo nosso).
} 
seres que participam dos jogos de linguagem, não se tratando de acordos sociais ou convencionais que se estabelecem exclusivamente entre seres humanos, mas sim entre humanos e não humanos que cooperativamente constituem formas de vida. Assim, se todo jogo de linguagem do "Não pense, veja?' necessariamente dá a ver o que significa, nenhum significa por si só o que dá a verr".

$\mathbf{M G}^{30}$ - "A crítica que LW faz à Doutrina da Cores se baseia justamente no fato de Goethe conceber a visão como forma de atividade e de ele mesmo acreditar numa possível descrição adequada dela. Segundo LW, a própria atividade pressupõe uma lógica das cores: "A análise fenomenológica (como, por exemplo, desejava Goethe) é uma análise conceitual e não pode nem definir a física, nem contradizê-la”. Se é a praxis que dá sentido às palavras, é porque revela as articulações entre os conceitos necessários para a indentificação das cores. LW não acredita no olhar "ingênuo" de Goethe, que poderia ter acesso, ou pelo menos vislumbrar a essência das cores. A visão, para LW, está imbricada com a linguagem, ou seja, com uma gramática conceitual sem a qual não poderíamos sequer identificar as cores. A linguagem simbólica da Doutrina das Cores faz parte dessa ilusão de que poderíamos ter uma linguagem única sobre as cores. Se ela é opaca, isso não impede que almeje uma transparência, uma universalidade. LW critica a ideia de uma linguagem unívoca sobre as cores".

$\mathbf{L W}^{31}$ - "A dificuldade que temos ao refletir sobre a essência das cores (que Goethe desejava enfrentar na Doutrina das Cores) consiste já no fato de que não temos um conceito único de identidade cromática, mas sim vários deles, uns aos outros aparentados".

DJ 32 - "De manhã, dei uma olhada nos índices dos meus livros - quem havia escrito sobre cores? Havia cor em ... filosofia ... psiquiatria ... medicina ... bem como em artes, e observações de cores e sobre elas ecoaram ao longo dos séculos".

LW" ${ }^{33}$ - "Uma cor brilha num contexto. Assim como os olhos apenas sorriem em um rosto".

$\mathbf{D J}^{34}$ - "À noite eu sonho com as cores. Alguns sonhos eu sonho em cores. De meus sonhos coloridos EU ME RECORDO”. Este é um de trinta anos atrás... Eu sonho com um 'Festival Glastonbury'. Há milhares de pessoas acampando ao redor de uma casa branca clássica, isolada em um gramado verde perfeito. Acima da porta da frente, o friso no tímpano é pintado em tons pastéis puros, representando as boas ações do proprietário. De quem é essa casa?

\footnotetext{
${ }^{29}$ Este nosso modo de significar o aforismo "Não pense, veja?' constitui uma paráfrase do ponto de vista de Salles (2012, p. 130, grifo nosso) acerca do poder de significação de uma figura: "É lição wittgensteiniana bastante conhecida a de que uma figura qualquer nada diz ao certo fora de um contexto. Por isso mesmo, um desenho idêntico pode ocorrer em diversas partes de um livro de física, significando, todavia, diferentemente a cada caso. Se toda representação mostra o que diz, nenbuma diz por si o que mostra".

30 Fala de Marco Giannotti na introdução que faz em sua tradução para o português da obra Doutrina das cores de Goethe (GOETHE, 1993, p. 25).

31 (LW, 2011, Parte IV-\$251, p. 167).

32 (JARMAN, 2010, p. 1).

33 (LW, 2011, Parte I, \55, p. 43).

34 (JARMAN, 2010, p. 2, tradução livre, grifos nossos).
} 
A resposta me é dada por um dos foliões: - A casa de Salvador Dali. Desde então, eu passei a olhar para as pinturas de Dali e descobri poucas cores nelas. Como uma criança eu me tornei ciente das cores e das suas mudanças.

ORGS - Poesia e imagem. Toda imagem é um ver como, um como se, um modo de significar por analogia, por comparação. Poesia significa por imagens. LW, em sua obra e em sua vida, falava e significava por imagens. Poetava. Fazia terapia. Como neste episódio reportado por sua irmã Hermine acerca da decisão do filósofo-poeta de se tornar professor de crianças camponesas de uma escola numa aldeia austríaca, na década de 1920:

$\mathbf{H W}^{35}$ - “A princípio, eu não consegui compreender a sua decisão [...]. E como nós, irmãos, nos entendíamos muitas vezes por meio de comparações, eu lhe disse, por ocasião de uma longa conversa à época, que imaginá-lo como professor de crianças era, para mim, como se alguém quisesse usar instrumentos de precisão para fabricar caixotes. Ludwig replicou com uma comparação que me fez emudecer: "Você me lembra alguém que olha através de uma janela fechada e não consegue explicar os movimentos estranhos de um passante; esse alguém não sabe do vento que sopra lá fora e nem que talvez o passante esteja fazendo muito esforço para se manter em pé".

ORGS - Eilenberger interpreta assim esta resposta-imagem do filósofo-poeta:

$\mathbf{W E}^{36}$ - "A imagem lembrada por Hermine revela não só a problemática existencial básica com a qual LW se confrontou durante toda a vida, mas também sua possível terapia. Pois a partir da metáfora altamente precisa do homem atormentado "diante da janela fechada", LW conseguiu "abrir sua janela"; quer dizer, conseguiu construir com sucesso uma ponte para o outro você, abrindo uma saída do isolamento mental em que se encontrava rumo à liberdade de ser compreendido. [...] Observando atentamente, a totalidade da obra filosófica de LW, também a mais tardia, é perpassada por metáforas e alegorias de libertação, da saída indicada e da evasão: "Qual o objetivo da filosofia? Mostrar à mosca a saída da redoma!". A atividade de filosofar [...] abre a janela à liberdade de uma existência ativa, perpassada de maneira direta pelos sentidos, vivida com os outros, ou seja, ao que ele chama no Tractatus de "felicidade". Ela abre a janela de um "outro mundo", pois: "O mundo do feliz é um mundo diferente do infeliz". E ele aponta o caminho a outro mundo através do meio que, sem a atividade esclarecedora do filosofar, ameaça obstruir, escurecer, distorcer, bloquear constantemente tal caminho: o meio da própria linguagem".

ORGS - “Não pense, veja?’ é uma imagem que não contrapõe o pensar ao ver. "Não pense, veja?' é uma imagem que propõe um novo modo de pensar: um pensar por imagens.

$\mathbf{L W}^{37}$ - "Você interpreta a nova concepção COMO SE fosse ela a visão de um novo objeto. Você interpreta um movimento gramatical que você fez COMO SE ele fosse um fenômeno quase físico que você está observando. (Pense, por exemplo, na questão "São os dados dos

\footnotetext{
35 Trecho de carta de Hermine Wittgenstein extraído de (EILENBERGER, 2019, p. 84-85, grifo nosso).

36 (EILENBERGER, 2019, p. 84-85, grifo nosso).

37 (LW, IF-401, destaques nossos em maiúsculas e itálicos).
} 
sentidos a matéria constitutiva do universo?"). Mas a minha expressão "você fez um movimento gramatical' não é indiscutível. Antes de tudo, você encontrou uma nova concepção. É COMO SE você tivesse inventado um novo estilo de pintura; ou até um novo metro, ou um novo tipo de canção".

ORGS - É desse modo que LW completa o esclarecimento que vinha dando ao seu interlocutor imaginário, ao longo dos parágrafos 394 a 401 das Investigações, acerca dos dois modos ${ }^{38}$ possiveis - interdependentes e não contrapostos de pensar -, isto é, de agir de modo significativamente compartilhado com os - ou orientado pelos - signos de um jogo de linguagem: 1) pensar-agir gramaticalmente, isto é, seguindo as regras gramaticais que orientam as ações no jogo sem dele participar ${ }^{39}$, como quando alguém, por exemplo, canta uma canção seguindo a gramática de uma partitura, ou pinta um quadro seguindo, por exemplo, a gramática do estilo impressionista de pintar; 2) pensar-agir através de imagens (Não pense, veja!), isto é, seguindo mimético-analogicamente as regras gramaticais que orientam as ações no jogo, como quando alguém, por exemplo, canta uma canção imitando e tentando reproduzi-la simplesmente vendo uma outra pessoa cantá-la, ou pinta uma pintura impressionista e tenta reproduzi-la simplesmente vendo e imitando os gestos de uma outra pessoa que a pinta, sem estar ciente da gramática do estilo impressionista de pintar. Ambos os modos de pensar ou agir de forma significativamente compartilhada são gramaticais no sentido de dependerem de uma gramática, mas não da mesma gramática: a gramática que orienta a voz de uma pessoa quando canta uma canção seguindo visualmente as regras de combinação dos sinais escritos/inscritos de uma partitura musical e dos grafemas da letra na linguagem escrita nativa da canção é diferente da gramática que orienta uma outra pessoa quando canta a mesma canção seguindo auditivamente as regras de combinação dos sinais sonoro-fonemáticos da linguagem oral nativa da letra da canção bem como as regras de combinação, articulação, modulação, entonação e expressão oral dos sinais sonoro-melódicos da mesma canção. A diferença entre esses dois modos de pensar/agir de forma significativamente compartilhada é a mesma que a que subsiste entre duas gramáticas diferentes, entre dois modos gramaticais diferentes de se realizar uma mesma prática, no caso, a prática do canto. Mas, o "Não pense, veja!" que orienta toda terapia gramatical do modo como LW nos dá a ver, não apenas recomenda como também pratica insistentemente o modo de pensar-agir mimético-analogico através de imagens. Acreditamos que esta insistência se deve à crença de LW de que quando pensamos ou agimos seguindo mecânica e cegamente as regras pré-estabelecidas de uma gramática, temos poucas ou nenhuma razão para (ou desejo de) aperfeiçoá-las, inová-las, modificá-las, o que exigiria transgredi-las. Já o pensar ou agir por imagens, dado que atrelado apenas a regras de gramáticas que podem ser seguidas por reprodução mimético-analógica, ignorando-as, ou mesmo desconhecendo-as, se mostram mais abertas e receptivas a desejos de transgressão, aperfeiçoamento, inovação, renovação, invenção, criação e de rupturas com a rotina, a normalização, a normatização, a cristalização, o hábito etc. E, nesse sentido, o "Não pense, veja!" precisaria ser visto como um COMO SE, pois ele nos é dado a ver por LW COMO SE

\footnotetext{
38 (MIGUEL, 2016a, p. 543).

39 Este orientar sem participar poderia ser visto, no sentido derridiano da palavra desconstrução - isto é, com base no modo como o filósofo Jacques Derrida desconstrói oposições binárias e, particularmente, a oposição binária entre presença e ausência que orienta toda a tradição falologocêntrica da metafísica ocidental -, como se as regras gramaticais orientadoras das ações dos participantes de um jogo de linguagem estivessem nem presentes e nem ausentes do jogo, isto é, como se participassem dele espectralmente, no sentido derridiano da palavra espectro.
} 
fosse a imagem de um apelo à descolonização do olhar. "É COMO SE você tivesse inventado um novo estilo de pintura; ou até um novo metro, ou um novo tipo de canção" (WITTGENSTEIN, s/d, IF-401, p. 216). É impossível, portanto, pensar de formas diferentes, pensar de outras maneiras desejo orientador de qualquer terapia gramatical wittgensteiniana -, sem se transgredir as regras da gramática orientadora de um jogo de linguagem; só a transgressão das regras da sua gramática nos permite participar dele de outras maneiras, isto é, orientados por novas gramáticas.

$\mathbf{A S}^{40}$ - "A música é um exercício inconsciente da filosofia, em que o espírito ignora que filosofa".

GL $\mathbf{H}^{41}$ - "A música é um exercício inconsciente da aritmética, em que o espírito ignora que calcula".

\section{O ver como o olho gramatical evolucionista vê}

$\mathbf{L} \mathbf{W}^{42}$ - "Uma curiosa analogia pode estar baseada no fato de que até mesmo a ocular do mais potente telescópio não pode ser mais sensível do que o olho humano”.

ORGS - O que nos dá a ver o olho gramatical evolucionista telescopicamente humano? O que ele nos dá a ver são futuros, metas, classes, etapas, categorizações, hierarquias, desenvolvimentos, progressos, glórias, triunfos, evoluções, construções, edificações, estruturas, fortalezas, fundações, fundamentos. E, por extensão, produção, comércios, indústrias, tecnologias, excedentes, mais-valias, expansionismos, imperialismos, colonizações, dominações, guerras.

ORGS - Navegar foi preciso. Mapear o mundo foi preciso. E mais do que simplesmente vêlo, foi preciso descrevê-lo, desenhá-lo detalhadamente em relatos de viagens e transformá-los em registros visuais precisos e fidedignos para olhos desejosos em transformar o que viam em mercadorias. Foi preciso, portanto, ver o que viam com o olho situado no mesmo plano da linha de terra, ao nível do nivel do mar, de modo que a linha do horizonte - a linha onde o mar das caravelas e das expedições desejava tocar o céu - lhe fosse coplanar. As geometrias projetiva e analítica foram invenções do olho gramatical deste novo artista-matemático que desejava ajustar com precisão especular a bússola e o astrolábio das rotas marítimas das caravelas e expedições à projeção de meridianos e paralelos no mapa-mundi de Mercator. Como disse o poeta português, "Deus ao mar o perigo e o abismo deu, mas nele é que espelhou o céu" "43. Navegar foi preciso! Navegar com precisão foi preciso - pelo menos desde o Jazãoargonauta em busca do velo de ouro, até mais ou menos Frazer em busca do ramo dourado havia sido o grande mote náutico bélico-civilizador que norteava o projeto colonialista europeu. A perspectiva cônica - isto é, o tipo de olhar do novo pintor artista viajante, humanista, mercantilista, colonialista - deseja ver-se (no) espelho da natureza. Registrar

\footnotetext{
40 Aforismo do filósofo alemão Arthur Schopenhauer, apud Somavilla (LW, 2012a, p. 110).

${ }^{41}$ Aforismo do filósofo alemão Gottfried W. Leibiniz, apud Somavilla (LW, 2012a, p. 110).

42 (LW, 1998a, p. 39); (LW, 2000/1931, p. 34, grifo nosso).

${ }^{43}$ Versos do poema Mar Português de Fernando Pessoa (PESSOA, 1959).
} 
visualmente as paisagens, dissecá-las para registrar as suas potencialidades exploratórias comercializáveis era a sua meta. Havia sempre artistas-cientistas e cientistas-artistas - cronistas, pintores, desenhistas, aquarelistas, arquitetos, urbanistas, paisagistas, topógrafos, geógrafos, zoólogos, botânicos etc. - entre os tripulantes das naus portuguesas ou espanholas ou holandesas ou inglesas ou francesas ou austríacas ou ... rumo às terras do Novo Mundo: Joaquim José Codina ${ }^{44}$ e José Joaquim Freire ${ }^{45}$, na "viagem filosófica" portuguesa ao Brasil chefiada por Alexandre Rodrigues Ferreira ${ }^{46}$; Albert Eckhout e Frans Post, na comitiva de Maurício de Nassau ao Brasil ${ }^{47}$; Thomas Ender, na missão austríaca ao Rio de Janeiro e São Paulo ${ }^{48}$; o zoólogo Johan Baptiste von Spix, o botânico Karl Friedrich Philipp von Martius ${ }^{49}$, o desenhista-topógrafo Hercule Florence ${ }^{50}$, os pintores Rugendas, Adrien Taunay, Nicolas Antoine Taunay, Felix Taunay, Jean-Baptiste Debret e muitos outros ${ }^{51}$. Essas imagens visuais e narrativas iriam constituir os documentos escritos e iconográficos nos quais as historiografias antropológicas whig dos séculos 18 e 19 nacionalistas, eurocentristas, edificantes, etapistas, progressivistas, colonialistas, racistas ... - iriam fundamentar as suas narrativas. Foi esse tipo de narrativa que o olho historiográfico-antropológico-gramatical de Frazer produziu. Foi nele que a linha do horizonte do seu olho gramatical, situado no mesmo plano da linha de terra, espelhou-se e espelhou o mundo. Foi com esse olhar perspectivo-cônico frontal situado na interseção da linha do horizonte do plano de representação com a linha de terra da paisagem que o seu olho de historiador-antropólogo-cientista-artista-colonizador irá descrever literariamente, em seu $O$ ramo dourado, os mitos, os ritos, os hábitos e as práticas dos povos de todos os cantos do mundo que o seu olho viu como "selvagens".

\footnotetext{
${ }^{44}$ Fontes: (AMBRIZZI, 2011, p. ); (https://www.brasilianaiconografica.art.br/autor/16993/joaquim-jose-codina), site visitado em 02 de dezembro de 2020.

45 (https://www.brasilianaiconografica.art.br/artigos/20197/jose-joaquim-freire-artista-engenheiro-e-militar). Site visitado em 02 de dezembro de 2020.

${ }^{46}$ Fontes: (SILVA, 2006, p. 131-143); (https://pt.wikipedia.org/wiki/Alexandre_Rodrigues_Ferreira). Site visitado em 02 de dezembro de 2020.

${ }^{47}$ Fonte: (SOARES, 2014).

48 Fonte: (RIBEIRO, 2007).

${ }^{49}$ Fonte: (LIMA, 2019).

${ }^{50}$ Fonte: (https://pt.wikipedia.org/wiki/Hércules_Florence).

51 (ARTISTAS Viajantes, 2021).
} 


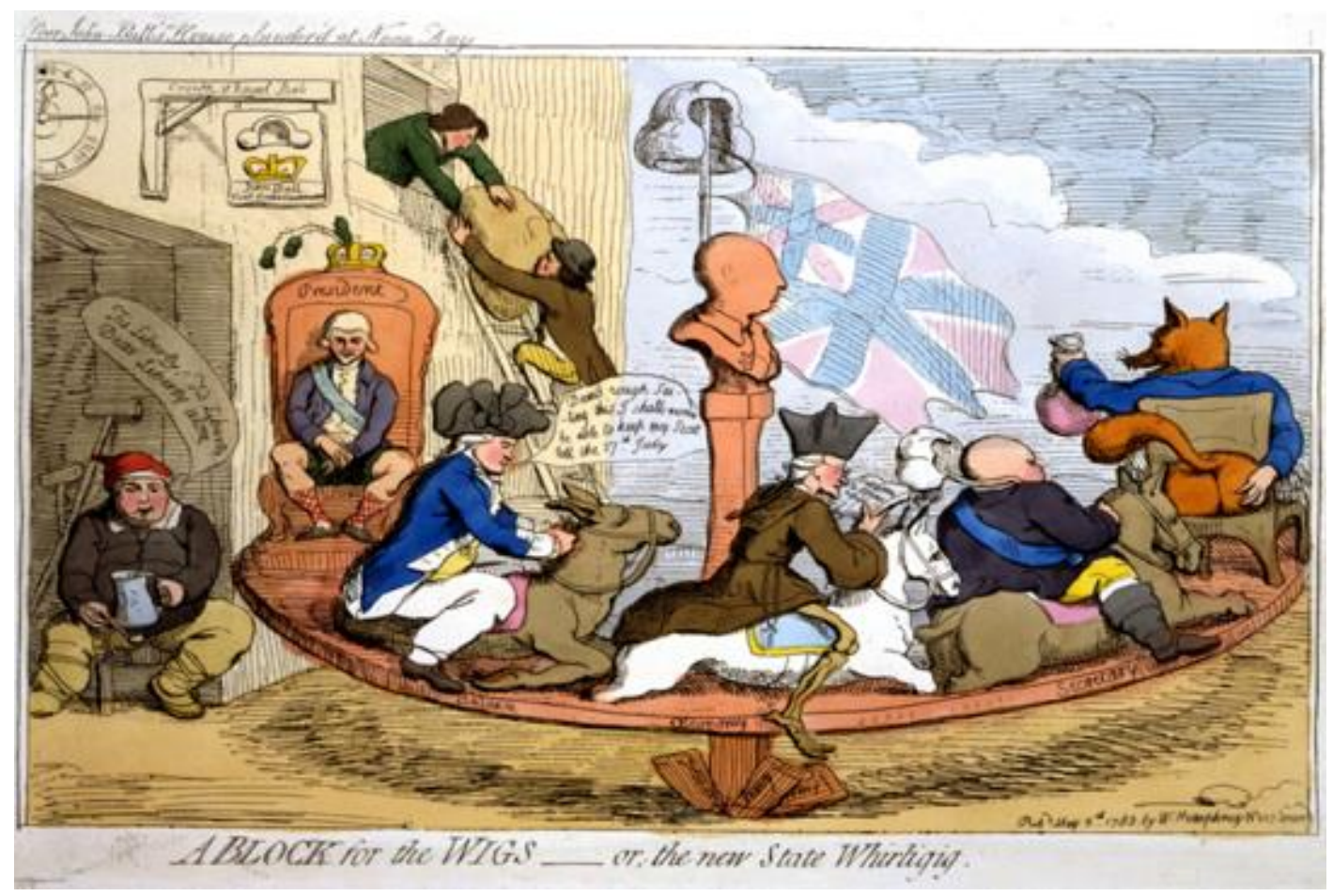

ORGS - A block for the Wigs, or the new State Whirligig ou Uma guilhotina para os whigs ou para o novo Estado Carrossel é o título deste cartum que se encontra na Divisão de Impressões e Fotografias da Biblioteca do Congresso, nos Estados Unidos. Ele foi publicado em Londres por W. Humphrey, em 05 de maio de 1783. No site em que o acessamos ${ }^{52}$, se diz que "o cartum mostra um carrossel no qual se sentam os ministros do governo [inglês] Charles Fox, Lord North, Edmund Burke e Almirante Keppel. A viga no centro da plataforma do carrossel é um pilar encimado por um busto do rei George III, uma peruca e a Union Jack [ou Union Flag, a bandeira nacional do Reino Unido] suspensa sobre o busto. No fundo, dois ladrões descem um grande embrulho pela janela de um prédio. Uma inscrição acima do desenho diz "Casa do pobre John Bull saqueada ao meio dia". Os trocadilhos incluem peruca [wig] para Whig [membros do Partido Whig] e block para significar dispositivo de decapitação, isto é, uma guilhotina - no desenho, o dispositivo em forma de cabeça para colocar perucas nas cabeças - e para significar a palavra blockhead, isto é, pessoa estúpida. No cartum, Burke está vestido como um jesuíta, está lendo Sublime and Beautiful e tem uma perna em forma de esqueleto". Whig era a designação do antigo Partido Liberal do Reino Unido - o Whig Party -, de orientação religiosa anti-católica, protestantecalvinista, fundado em 1678 e dissolvido em 1861, e no qual o atual Partido britânico Liberal Democrats, formado pela fusão do Partido Liberal com o Partido Social Democrata, teve a sua base remota de formação. A palavra whig deriva da palavra escocesa whiggamore que significa "condutor de gado", termo usado para designar os escoceses que vinham ao porto de Leith, na cidade de Edimburgo, para comprar milho. A palavra surge no contexto da guerra civil inglesa dos Três Reinos (1639-1651), na qual foi usada

\footnotetext{
52 Disponível em: <https://pt.wikipedia.org/wiki/Partido_Whig_(Reino_Unido)\#/media/Ficheiro:A-Block-for-theWigs-Gillray.jpeg), James Gillray - Library of Congress, Prints \& Photographs Division, LC-USZC4-6861 (color film copy transparency), Criação: 5 de maio de 1783. Acessado em: 05 de novembro de 2020.
} 
pejorativamente pelos políticos católicos conservadores contra os políticos protestantes de orientação liberal que, posteriormente, fundariam o Partido Whig que se organizou com base no propósito compartilhado de se lutar pela instalação de um regime parlamentarista protestante, de orientação liberal, na Inglaterra. Tal partido acabou se tornando um dos mais influentes no sistema parlamentar britânico até o final da Primeira Guerra Mundial, após a qual foi perdendo a sua força e importância para o Partido dos Trabalhadores, o Labour Party ${ }^{53}$ Historiografias whig são, portanto, narrativas historicistas que não apenas apresentam o passado como uma progressão inevitável em direção a um futuro luminoso, feliz e não obscurantista, como também, ao elegerem um determinado modo de organização sócio-político-econômico-cultural instituída como o limite teleológico modelar de nação civiliz̧ada para o qual deveriam tender todas as nações, acabam por constituir o passado de todos os povos e nações como uma temporalidade menos civilizada em relação aos seus presentes, de modo que o campo geopolítico global das nações, em qualquer momento temporal, é dividido entre, por um lado, nações mais ou menos civilizadas, bárbaras, selvagens ou primitivas, dependendo do quão próximas ou afastadas elas estejam do modelo eleito de nação civilizada.

ORGS - Foi um tal tipo de orientação whig ou historicista no modo de se conceber, investigar e produzir narrativas antropológico-historiográficas a eleita por Frazer na escrita de sua obra $O$ ramo dourado. E foi justamente sobre essa obra que LW fez operar, pela primeira vez - e com plena convicção de que ele havia inventado um novo método de investigação filosófica -, a sua crítica terapêutico-gramatical. Assim, as Observações sobre o Ramo Dourado de Frazer - um texto postumamente publicado que reúne um conjunto de considerações críticas esparsas que LW fez, ao longo da década de 1930, a essa obra de Frazer - embora não nos dê a ver, diretamente, com o que se assemelharia uma historiografia terapêutica propriamente wittgensteiniana, nos mostra isso, indiretamente, através da crítica terapêutica que faz o filósofo a um texto de natureza antropológico-historiográfica, antes mesmo (ou paralelamente) dele ter estendido o seu método ao próprio domínio da filosofia, do modo como ele o praticou nas Investigações filosóficas. E tendo presente os ecos dos métodos morfológicos de Goethe e de Spengler na constituição de uma possível fisiognomia de uma investigação historiográfica terapeuticamente orientada e praticada, seria possível, de certo modo, identificar em que consisitiria a originalidade e a potencialidade que um método terapêutico-gramatical teria trazido para a condução de investigações historiográficas desde então. Uma vez, entretanto, que a fisiognomia de uma historiografia terapêutica - e o próprio modo como LW a pratica no sentido de se desconstruir, desfazer, dissolver nós e mal-entendidos - se constituiu em conflito e em confronto com historiografias whig e, particularmente, com historiografias antropológicas colonizadoras a la Frazer, poderíamos dizer que um aspecto dessa fisiognomia é a sua característica decolonial ${ }^{54}$, desde que signifiquemos esse adjetivo de um modo bastante peculiar, para caracterizar a terapia gramatical como um método que opera quer no sentido negativo de descolonizar o olhar, isto é, de desconstruir imagens ilusórias, falsas, fixas, cristalizadas, ideológicas etc. nos modos de se lidar com um determinado problema, quer

\footnotetext{
${ }^{53}$ Fontes: (https://pt.wikipedia.org/wiki/Solemn_League_and_Covenant);

(https://pt.wikipedia.org/wiki/Partido_Whig_(Reino_Unido). Acessos em: 05 de novembro de 2020.

${ }^{54}$ Miguel \& Tamayo defendem esse ponto de vista na referência (MIGUEL \& TAMAYO, 2020).
} 
no sentido positivo de nos dar a ver, de colocar diante de nossos olhos, outras imagens mais adequadas de se ver e lidar com o problema. É o que nos sugere, por exemplo, a seguinte passagem das Observações sobre o Ramo dourado:

$\mathbf{L W}^{55}$ - "Frazer é muito mais selvagem que a maioria dos seus selvagens, pois estes não estariam tão longe da compreensão de uma questão mental remota quanto um inglês do século XX. Suas explicações das práticas primitivas são muito mais toscas que o próprio sentido dessas práticas".

ORGS - A esta passagem, Almeida, o tradutor para o português das Observacões sobre o Ramo dourado, chama uma nota ${ }^{56}$ com o propósito de esclarecer os leitores de que, no seu texto, escrito em alemão, LW intencionalmente escreve a palavra "selvagem" não no alemão "wilder", mas no inglês "savage", a fim de acentuar a ironia.

$\mathbf{L W}^{57}$ - "Que estreiteza da vida mental da parte de Frazer! E que impossibilidade de conceber uma outra vida diferente da inglesa do seu tempo! Frazer não consegue pensar em nenhum sacerdote que não seja, fundamentalmente, um pároco inglês do nosso tempo, com toda a sua estupidez e debilidade. [...] A apresentação que faz Frazer das concepções mágicas e religiosas dos seres humanos é insatisfatória: ela faz com que essas concepções apareçam como erros. Estava, então, Agostinho errado quando invocava a Deus em cada página da Confissões? E se ele não estava errado, então, quem estava, poder-se-ia dizer, era o santo budista - ou outro qualquer - cuja religião expressa concepções completamente diferentes. Mas nenhum deles estava errado. Exceto quando afirmava uma teoria”.

$\mathbf{A M}_{\mathbf{2}} \mathbf{C T}^{58}$ - Esta crítica de LW recai sobre o pressuposto cientificista que orienta a narrativa historiográfico-antropológica whig de Frazer. A objeção que faz LW ao desejo frazeriano de explicar cientificamente uma prática dogmático-religiosa e, portanto, metafísica, é da mesma natureza que a objeção feita ao desejo inverso de explicar dogmaticamente, isto é, através de teorias metafísicas, uma hipótese científica para a qual, portanto, é possível acumular um con- junto de evidências empíricas que a reforcem ou que a refutem. É por isso que, para LW, não há nada de errado com Agostinho, com Buda ou com qualquer outra prática dogmática de caráter religioso ou mágico, a não ser quando se manifesta e se leva adiante o desejo de teorizá-las, de explicá-las cientificamente, isto é, quando se tenta assentar a fé na razão, racionalizar ou explicar racionalmente a fé, como o fizeram, por exem- plo, as inúmeras 'provas científicas' da existência de Deus ao longo da história da filosofia e da religião. Ou então, quando ao cientista se manifesta o desejo oposto de assentar a razão na fé, isto é, de transcendentalizar a razão, de explicar o fenômeno ou problema sob investigação empírica com base em teorias metafísicas, transcendentais, inacessíveis, elas próprias, ao controle observacional ou experimentalperceptual. E é aí que se manifesta o erro de Frazer, segundo LW.

\footnotetext{
55 (LW, 2007, p. 200).

56 Trata-se da Notas 78 contida na referência (LW, 2007, p. 221).

57 (LW, 2007, p. 192-193).

58 (MIGUEL\&TAMAYO, 2000, p. 24-25, grifo nosso).
} 
AM\&CT ${ }^{59}$ - "Historiografias whig e, mais amplamente, historiografias historicistas como a de Frazer se orientam pela crença cientificista na lei dos três estados de Comte. Essa lei pressupõe que tanto um ser humano, na sua história individual, quanto as sociedades humanas, em suas histórias coletiva, tendem a passar pelos mesmos estados epistêmico-metodológicos em relação ao modo sequencial evolutivo e linear de explicar e de se lidar com os fenômenos naturais, quais sejam: o estado teológico, o estado metafísico e o estado positivo ou científico. No estado teológico, as ex- plicações tendem a ser especulativas, isto é, explicações que tendem a recorrer a divindades sobrenaturais, não estando, portanto, baseadas em experimentações e evidências empíricas; no estado metafísico, as explicações tendem a ser lógico-argumentativas, abstratas e causais, mas igualmente alheias a experimentações; no estado positivo, as explicações meramente argumentativas tendem a ser confrontadas com a observação, com a experimentação com o propósito de inferir as leis que governam os fenômenos".

$\mathbf{A M} \& \mathbf{C T}^{\mathbf{6 0}}$ - "O pressuposto comum subjacente a todas as narrativas historiográficas historicistas tem a sua expressão na denominada lei biogenética de Haeckel. Segundo essa lei, todas as formas humanas ou não humanas de vida, em um dado momento temporal, poderiam ser vistas como o resultado de suas configurações temporalmente antecedentes. Extensões metafóricas dessa crença naturalista produzida com base em estudos de morfogênese acabaram estimulando a produção de incontáveis teorias evolutivas, evolucionistas ou desenvolvimentistas lineares, cíclicas ou dialéticas - em todos os campos de atividade científica: na física, na biologia, na história, na antropologia, na linguística, na psicologia e também, é claro, no terreno das pedagogias ditas científicas. "No campo da pedagogia, essa febre evolucionistaetapista colonizadora transfigurou a criança em infante, bem como, em infância, não só o período temporal de imaturidade biológica para procriar e assegurar a continuidade da espécie, mas também, o período cultural a ele correspondente, agora transfigurado em período temporal de incapacidade generalizada e/ou de preparo para a aquisição de capacidades por vir". A partir do final do século 19, essas extensões metafóricas ilegítimas da igualmente controversa lei biogenética de Haeckel acabaram também definindo políticas organizacionais e curriculares para os sistemas nacionais de educação escolar em quase todo o mundo.

\footnotetext{
${ }^{59}$ (MIGUEL\&TAMAYO, 2000, p. 22-23, grifo nosso).

60 (MIGUEL\&TAMAYO, 2000, p. 23, grifo nosso).
} 
ORGS - Uma imagem da batalha de Arcole, segundo o olho gramatical napoleônico de Horace Vernet $^{61}$.

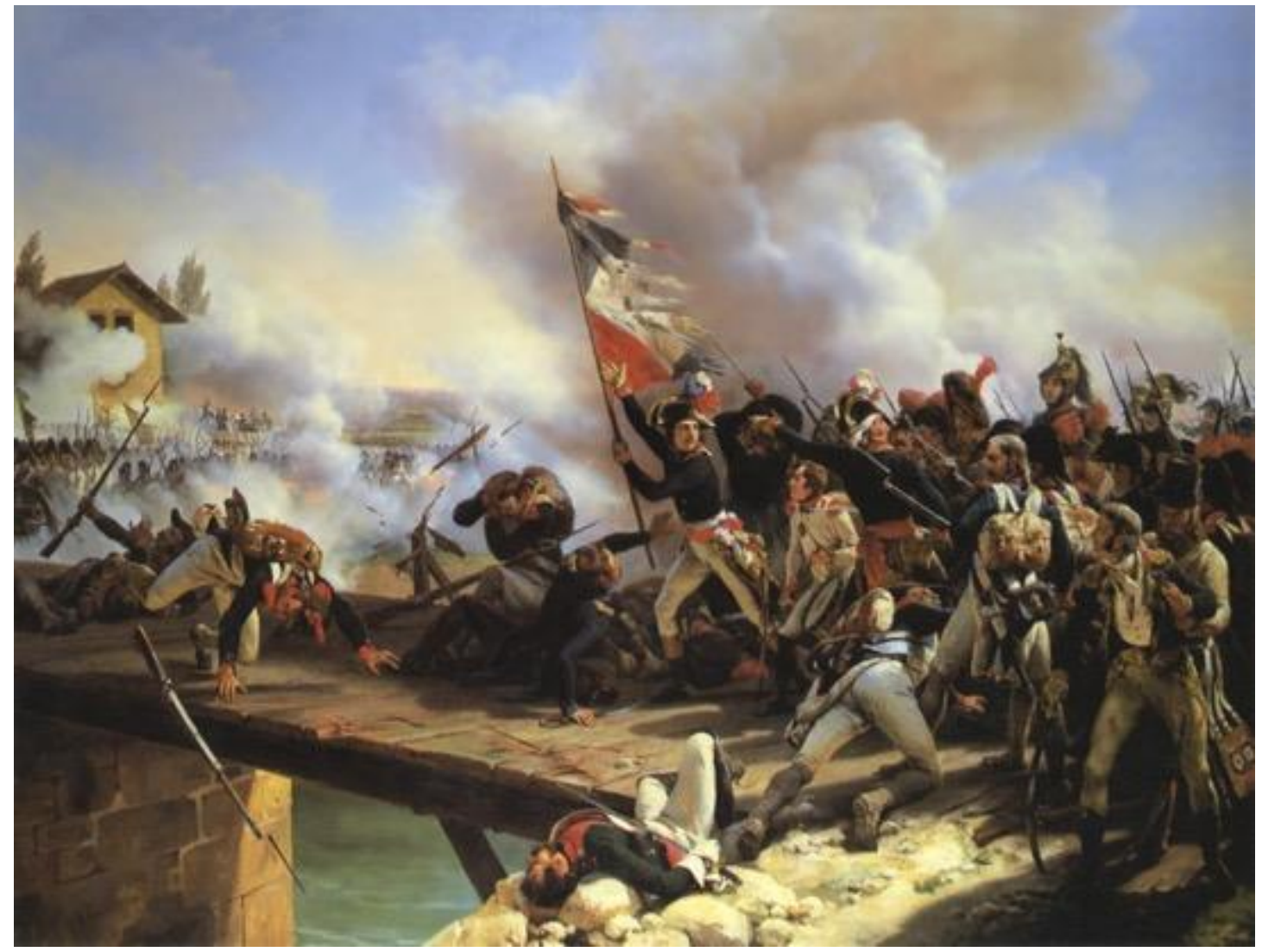

HV\&MB \& DC D2 $^{2}$ " A batalha de Arcole ocorreu em 15 de novembro de 1796, na ponte de Arcole, na atual Itália. Os combatentes eram a Primeira República Francesa e o Império Austríaco. Foi uma manobra ousada de Napoleão Bonaparte. A vitória da Primeira República Francesa provou ser o acontecimento-resposta mais significativo diante da terceira investida da Áustria de começar o cerco de Mântua, durante a Guerra da Primeira Coligação. O desfecho foi a vitória austríaca em baixas e a vitória francesa taticamente. Um grande gesto de coragem de Napoleão Bonaparte que é reconhecido até hoje. Diz a história, que para servir de exemplo de coragem e força para os outros soldados, Napoleão pegou a bandeira do porta-bandeira francês e, junto ao exército, correu em linha de frente sem estar armado, arriscando sua própria vida. Esta vitória e o gesto de coragem feito por Napoleão foi reconhecido pelo exército e pelo povo francês que, a partir desta e outras batalhas, passaram a considerá-lo um grande lider".

\footnotetext{
${ }^{61}$ Óleo sobre tela do pintor francês Émile Jean-Horace Vernet (1789-1863), intitulado La Bataille du Pont d'Arcole, produzido em 1826, 37 anos após a revolução francesa. Renomado por suas pinturas panorâmicas de batalhas que registraram artístico-visualmente, edificando-os, os feitos da era napoleônica. "Uma anedota conta que quando Vernet foi convidado a remover um determinado general desagradável de uma de suas pinturas, ele respondeu: "Eu sou pintor de história, senhor e não violarei a verdade", demonstrando a sua fidelidade com a representação real da guerra" (itálicos nossos). Disponível em: < https://pt.wikipedia.org/wiki/Horace Vernet\#cite ref-2 >. Acesso em: 05 dez. 2020.

${ }^{62}$ Uma descrição sintética (itálicos nossos) da composição de imagens textuais e iconográfica da batalha de Arcole baseada nas fontes:

(https://pt.wikipedia.org/wiki/Batalha da ponte de Arcole);

(https://pt.wikipedia.org/wiki/Horace Vernet\#cite ref-2), acessadas em 03 nov. 2020.
} 
ORGS - A imagem iconográfica da batalha de Arcole por Vernet sobreposta à imagem textual da mesma batalha produz uma imagem de uma historiografia whig - teleológica, nacionalista, imperialista, edificante, colonizadora. Cada uma dessas imagens tomadas separadamente também produzem o mesmo efeito. Elas nos dão a ver imagens de Napoleão que o retratam como herói luminoso e iluminado, imagens que enaltecem os seus feitos, a sua capacidade como estrategista militar e o seu poder imperial colonializador.

NTH - "As águas são azuis e as plantas são róseas; doce é contemplar o entardecer. Passeia-se. As grandes damas vão passear; atrás delas pequenas damas vão se passando" 63 .

ORGS - A razão pela qual Benjamin elege versos de um poeta vietnamita como uma das epígrafes do capítulo de abertura intitulado Paris, capital do século XIX do seu livro inacabado Passagens permanece, até hoje, desconhecida e pouco ou nada estudada. Após quase um milênio de colonização pela China imperial, o Vietnã, a partir de meados do século 19, passou a ser uma das colônias francesas na Indochina. Só após a denominada Guerra da Indochina, ocorrida de 1946 a 1954, que deixou mais de 400 mil mortos, o Vietnã se tornou um país independente devido, sobretudo, à luta anticolonialista travada pelos vietnamitas comunistas contra os franceses. Benjamin morreu sem ver a passagem da paisagem do século XIX europeu - confiantemente iluminista, progressista e colonizador - metamorfosear-se em ruinas após as ruínas da segunda guerra mundial. Parece, entretanto, que ele nos deu a vê-la, com seu olho antiteleológico-evolutivo de vidente, no último parágrafo de Paris, a capital do século XIX, esta imagem das ruinas do colonialismo europeu e, por extensão, das ruinas da historiografia whig - nacionalista e edificante ${ }^{64}$.

$\mathbf{W B}^{65}$ - "Balzac foi o primeiro a falar das ruinas da burguesia. Mas só o surrealismo liberou-as à contemplação. O desenvolvimento das forças produtivas deixou em pedaços os símbolos dos desejos do século anterior, antes mesmo que desmoronassem os monumentos que os representavam. No século XIX, tal desenvolvimento emancipou as formas configuradoras

\footnotetext{
${ }^{63}$ Versos do XXV poema da obra intitulada "Paris capital da França: coletânea de versos”, publicada em Hanói, em 1897, do poeta vietnamita Nguyen-Trong-Hiep, eleitos por Walter Benjamin como uma das epígrafes do capítulo intitulado "Paris, capital do século XIX” de sua obra inacabada "Passagens" (BENJAMIN, 2009, p. 39).

${ }^{64}$ É esta a imagem anticolonial que o filósofo e teórico da literatura Gerardo Muñoz faz da citação dos versos de Hiep por parte de Benjamin em sua matéria intitulada "Benjamin y un poeta vietnamita" publicada em seu blog Puente Ecfratico, postada em 21 de junho de 2012: "El libro Paris, capitale de la France: recueils de vers de Trong Hiep es un típico producto del imperialismo cultural europeo y del viaje estético, al decir de David Viñas, desde las periferias a los centros culturales. Aunque Benjamin solo cita uno de los poemas de un libro de noventa páginas, cualquier página del libro del vietnamita pudiera dar cuenta de los procesos de esa imaginación colonial frente a los avances culturales de la sociedad capitalista. La incipiente capital del siglo XIX aparece en el libro de Hiep, como en la poética modernista parnasiana de Rubén Darío, desde la artificialidad, el ensueño, los prototipos sociales de la burguesía, y la fascinación generada por las mercancías. Todos estos fueron los temas que parecieran condensar el proyecto que Benjamin quiso plasmar en su imaginario de París. El mismo título del importante ensayo de Benjamin "Paris, Capital del Siglo Diecinueve", pudiera ser leído como una rescritura del título del poeta vietnamita. Si no fuese porque Benjamin aconsejaba leer desde lo microscópico, la referencia a Nguyen Trong Hiep no tuviese la más mínima importancia. Pero justamente por eso, localizar el lugar central que Benjamin le concede al poeta vietnamita, legitima preguntar la relación que el proyecto histórico-filosófico de Benjamin sostuvo con los imaginarios coloniales y poscoloniales. ¿Hasta qué punto no podemos leer los conceptos de Benjamin (la constelación, la imagen-dialéctica, el ahora-tiempo, o la noción de gestos) como figuras que se acercan a una comprensión europea con sus periferias? ¿No es posible leer la cita de Hiep como una futura estrategia conceptual para pensar la heterogeneidad de la historia mundial fuera del eurocentrismo? París es, en este sentido, el espacio crítico no solo del capitalismo, sino de los modos concretos de la colonización". Disponível em: (http://gerrypinturavisual.blogspot.com/2012/06/benjamin-y-un-poeta-vietnamita.html). Acesso em 03 de novembro de 2020.

65 (BENJAMIN, 2009, p. 46, grifo nosso).
} 
da arte, assim como no século XVI as ciências se livraram da filosofia. As criações da fantasia se preparam para se tomarem práticas enquanto criação publicitária. Com o folhetim, a poesia se submete à montagem. Todos esses produtos estão a ponto de serem encaminhados ao mercado enquanto mercadorias. Mas eles ainda vacilam no limiar. Desta época é que se originam as passagens e os interiores, os salões de exposição e os panoramas. São reminiscências de um mundo onírico. A avaliação dos elementos oníricos à hora do despertar é um caso modelar de raciocínio dialético. Por isso é que o pensamento dialético é o órgão do despertar histórico. Cada época não apenas sonba a seguinte, mas, sonhando, se encaminha para o seu despertar. Carrega em si o seu próprio fim e - como Hegel já o reconheceu - desenvolve-o com astúcia. Nas comoções da economia de mercado, começamos a reconhecer como ruinas os monumentos da burguesia antes mesmo que desmoronem".

$\mathbf{W B}^{66}$ - "O anjo da história deve ter esse aspecto. Seu rosto está dirigido para o passado.

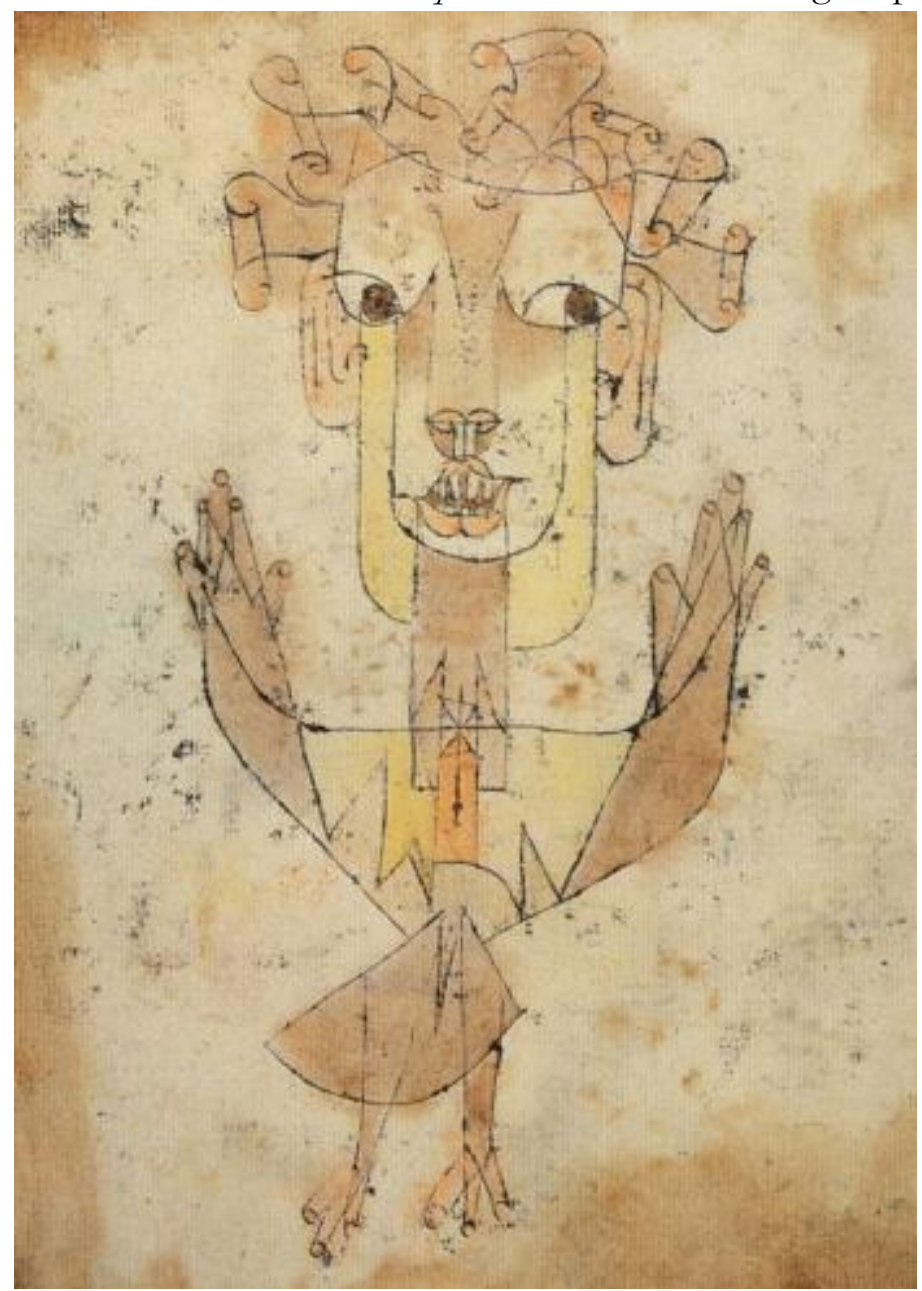

${ }^{66}$ Imagem produzida por Walter Benjamin (apud HARTOG, 2017, p. 121-122, grifo nosso) do Angelus Novus (Anjo Novo) de Paulo Klee. O Anjo novo é um desenho de 1920 feito com nanquim, giz pastel e aquarela sobre papel, pelo pintor e poeta suíço-alemão Paul Klee (1879-1940). A aquarela se econtra no Museu de Israel, em Jerusalém. Segundo o filósofo e historiador judeu-alemão Gershom Scholem (1897-1982), "Benjamin tinha uma espécie de identificaşão mistica com o Angelus Novus e incorporou isso em seus escritos sobre o "anjo da história", numa melancólica visão do processo bistórico como um incessante ciclo de desespero". Fonte da imagem do Anjo novo de Klee:

(https://pt.wikipedia.org/wiki/Angelus Novus). Acesso em 03 de novembro de 2020. 
Onde nós vemos uma cadeia de acontecimentos, ele vê uma catástrofe única, que acumula incansavelmente ruina sobre ruína e as dispersa a nossos pés. Ele gostaria de deter-se para acordar os mortos e juntar os fragmentos. Mas uma tempestade sopra do paraíso e prende-se em suas asas com tanta força que ele não pode mais fechá-las. Essa tempestade o impele irresistivelmente para o futuro, ao qual ele vira as costas, enquanto o amontoado de ruínas cresce até o céu. Essa tempestade é o que chamamos progresso".

$\mathbf{F A}^{67}$ - "Com este anjo, passa-se do gênio conquistador com olhos de águia ao anjo impotente que contempla a acumulação das ruínas. Não se está mais no regime da historia magistra, mas tampouco no regime moderno, o da história que marcha incessantemente adiante. Precisamente, veem-se seus efeitos destruidores. [...] Lá onde queremos perceber uma cadeia de acontecimentos, um tempo linear de causas e efeitos, o anjo tem essa visão sinóptica, distante, que lhe permite perceber uma catástrofe única. Levado pelo vento do progresso, ele não pode realizar os ritos funerários apropriados e abrir a era messiânica da futura sociedade sem classes".

ORG 3 - De acordo com o vento gramatical que agita o retângulo cromático da bandeira empunhada pela imagem do anjo-mulher-liberdade de Delacroix ${ }^{68}$, a igualdade é não é branca, a fraternidade não évermelha e a liberdade não é azul.

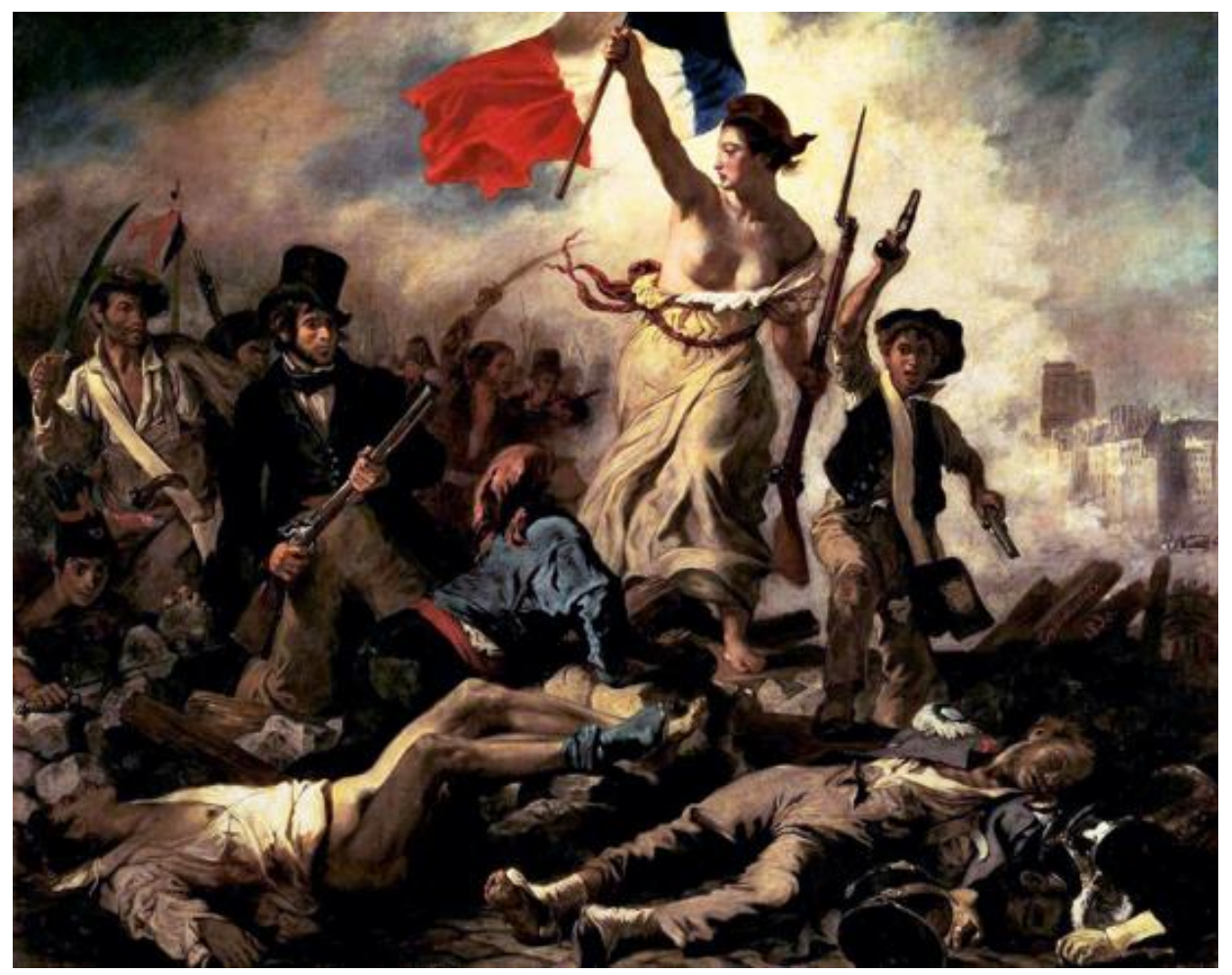

ORG 3 - Já para o vento gramatical progressista que Benjamin e Hartog veem e ouvem soprar do paraíso e manter abertas as asas do anjo de Klee, a igualdade, a fraternidade e a liberdade dissolvem-se, quase indistintas, na poeira monocromática das ruínas terrocotas que ele

\footnotetext{
${ }^{67}$ Esta é a imagem produzida pelo historiador francês François Hartog (2017, p. 121-122) do Anjo novo da história de Klee \& Benjamin.

68 Óleo sobre tela de pintor francês Eugène Delacroix (1798-1863), intitulado A liberdade guiando o povo (1830). Disponível em: (https://www.wikiwand.com/pt/Pintura_do_Romantismo_brasileiro). Acesso em 03 de novembro de 2020.
} 
levanta e na qual o anjo se acha envolvido. Parece-me que, aos olhos de Benjamin e Hartog, o anjo de Klee paira indeciso, de olhos lucidamente abertos, entre as ruínas do passado e as incertezas do futuro. Já o anjo-mulher-liberdade de Delacroix, embora também esteja com a cabeça voltada para trás, não hesita em voltar as costas para as ruinas do passado ou em ignorar os corpos já mortos que tombaram na luta em seu nome, no presente, e que nos são dados a ver pelo pintor situados fora do campo de visibilidade do anjo-mulher. Cega para o passado e para o presente, a preocupação do anjo-liberdade-mulher parece concentrar-se, exclusivamente, em indicar confiantemente aos que conseguiram se manter vivos na luta, o caminho para um futuro luminoso e glorioso de liberdade, paz e felicidade que certamente - e deterministicamente - estaria lhes preparando o futuro.

$\mathbf{P K}^{69}$ - "O que nós vemos é só aparência. A arte não reproduz o visivel, ela torna visivep".

ORG 2 - É... é uma outra maneira de ver... mas que não nos dá a ver porque razão o "anjo" de Delacroix não tem asas, isto é, porque ele o veria como anjo...

ORG 1 - E nem nos dá a ver porque razão ele o vê e pinta como uma mulher... A rigor, anjos não têm sexo... Então, ORG 3, você é que precisa nos dizer porque você ainda o vê como anjo, já que não podemos duvidar de que o que todos nós estamos vendo - e que também Delacroix nos dá a ver - é a imagem da liberdade como uma mulher, e não como um anjo...

ORG 2 - ... uma imagem whig luminosa tipicamente evolutiva e progressiva da história que nos é dada a ver, inclusive, em quase todos os hinos nacionais das nações americanas escritos em louvor a suas pátrias, após a proclamação das denominadas repúblicas, isto é, após o vento da tempestade vindo do paraíso-futuro ter soprado suficientemente forte para manter abertas as asas supostamente invisiveis deste anjo-mulher que indicará o caminho da libertação de um povo das garras da águia colonizadora - este animal de rapina - que sobrevoava panoramicamente territórios alheios, de olhos bem abertos para as suas riquezas... Cabe, então, ao futuro luminoso libertar o passado de ruínas e trevas da opressão imperial colonizadora.

MA \& $\mathbf{L M}^{70}$ - Seja um pálio de luz desdobrado

Sob a larga amplidão destes céus

Este canto rebel que o passado

Vem remir dos mais torpes labéus!

Seja um bino de glória que fale

De esperanças de um novo porvir!

Com visões de triunfos embale

Quem por ele lutando surgir!

\footnotetext{
${ }^{69}$ Aforismo (itálicos nossos) do artista plástico alemão Paul Klee que abre o filme documentário $O$ diário de um artista. Disponível em: (https://www.youtube.com/watch?v=tI-mW8mZfjU). Acesso em 03/11/2020.

${ }^{70}$ Imagem do anjo da liberdade que nos é dada a ver nas três primeiras estrofes (itálicos nossos) do Hino da Proclamação da República do Brasil, cuja música foi composta por Leopoldo Augusto Miguez (1850-1902) e cujo poema, publicado no Diário Oficial de 21 de janeiro de 1890, foi composto por Medeiros e Albuquerque (1867-1934). Fonte acessada em 03 de novembro de 2020:

(https://pt.wikipedia.org/wiki/Hino_da_Proclamação_da_República).
} 


\section{Liberdade! Liberdade! \\ Abre as asas sobre nós}

Das lutas na tempestade

Dá que ouçamos tua voz.

ORG 3 - É que eu... propriamente... não estou vendo - mas sim ouvindo a imagem-símbolomulher-liberdade de Delacroix como se ela fosse um anjo falante-de-asas-invisiveis que estivesse gritando aos ouvidos de seus compatriotas algo semelhante ao confiante apelo de d'Alembert aos matemáticos de seu tempo para se deixarem levar de olhos fechados pelo fluxo linear do progresso científico sempre para o bem, para o bom, para o belo, para o verdadeiro, para o justo... deixando que o futuro luminoso do acaso lhe prepare os fundamentos: - "Sigamos em frente, que a fé virá depois!". É a imagem deste grito de um d'Alembert ausente na cena da pintura que ouço no grito mudo deste anjo-mulher com asas invisiveis. É o mesmo grito mudo de independência ou morte que dá D. Pedro I às margens do Ipiranga e que a gente vê sem ouvir na cena da pintura de Pedro Américo ${ }^{71}$. Lembre-se de que no poema deste mesmo hino da Proclamação da República que você nos deu a ver sem ouvir, há também o verso: Do Ipiranga épreciso que o brado seja um grito soberbo de fể . É um grito voluntarista não-racional de fé na razão! E é por isso que ele nos é dado a ver por uma mulher, que ele é visto e pintado como o grito mudo de impulsividade, intuição e imaginação de uma mulher, na imagem de Delacroix. E é também por isso que o anjo-mulher-sem-asas de Delacroix não precisa ter asas... não precisa mostrar-se alado, como todos os demais anjos. E é por isso também uma mulher... ele é a impulsividade, a imaginação, a intuição feminina... De uma mulher que é por ele vista e pintada como o oposto da razão, dado que a razão lhe aparece como se fosse masculina... Não pensem, vejam! Só há homens - vivos ou mortos - nesta pintura de Delacroix. A única mulher é justamente este anjo-estrela-guia-sem-asas guiando o povo rumo a um futuro luminoso, feliz, racional e racionalmente prevísivel. É por isso que Delacroix decidiu nomear esta sua pintura " $A$ liberdade guiando o povo".

ORG 2 - É surpreendente como o seu ouvido consegue ouvir vozes que o nosso olho não consegue ver... Mas, de certo modo, você tem razão... Não foi a própria racionalidade do matemático d'Alembert quem argumentou contra a sensibilidade intuitiva, impulsiva e imaginativa do seu amigo artista Diderot que o cinzel do mais hábil estatuário não produz sequer uma epiderme, isto é, que não permite que um corpo passe do estado de sensibilidade inerte ao de sensibilidade ativa? Esta luta agonística entre o olho e o ouvido, entre razão e sensibilidade, entre razão e paixão, entre razão e intuição, natureza e cultura no discurso dos empiristas europeus do século XVIII reflete-se, de fato, na oposição que eles estabeleciam entre a imagem de homem e a imagem de mulher. Nesta oposição, o aspecto fisiognômico característico da imagem de mulher era, de fato, aquele que a razão masculina acessada pelos cinco sentidos não conseguiam ver, qual seja, o sexto sentido: a fé...

\footnotetext{
${ }^{71}$ ORG 3 está se referindo ao óleo sobre e tela intitulado Indendência ou morte (1888) do pintor brasileiro Pedro Américo que se encontra no Museu Paulista da Universidade de São Paulo. Seu nome se inspira no dito de D. Pedro I ao proclamar a independência do Brasil, em 7 de setembro de 1822: "É tempo! Independência ou Morte! Estamos separados de Portugal?". Disponível em:

<https://pt.wikipedia.org/wiki/Independência_ou_Morte_(Pedro_Américo)>. Acesso em 03 nov. 2020.

72 Verso do Hino da Proclamação da República do Brasil (ver nota 70).
} 
ORG 1 - ... fé cega, faca amolada! A rigor, não se tratava de oposição entre homem e mulher, entre razão e fé, mas de uma relação de complementaridade ou de dependência mútua entre uma fé cega guiando a faca amolada da razão. Foi esta outra imagem que me remeteu ao bispo George Berkeley $^{73}$, mais precisamente à crítica que a faca amolada da sua razão fideísta afiada dirigia contra a visivel falta de fundamentos que o edifício matemático, imagem-monumento da razão, começava a manifestar através das inexplicáveis, porém, visiveis rachaduras nele provocadas por um conjunto de paradoxos revelados pelas aplicações praxiológicas da Análise - era este o nome que se dava, na época, ao Cálculo Diferencial e Integral -, novo campo de investigação matemática que, até então, retirava os seus fundamentados lógico-racionais exclusivamente da "velha" geometria euclidiana, tida como a única e verdadeira teoria acerca do espaço físico real ${ }^{74}$. Foi contra esse grito metafísico anti-abstracionista - porém, idealista, fundacionista e fundamentalista - que via e punha em evidência paradoxos lógicos, dado pela vo z fideísta da religiosidade anglicana ${ }^{75}$ de Berkeley, que se insurgiu paradoxalmente o grito sensivel-fideista dado pela voz empirico-pragmática laica de d'Alembert ${ }^{76}$. Não pensem! Vejam o subtítulo do livro $O$ analista do bispo Berkeley, no qual ele fundamentou imaterialmente a sua crítica: "Um discurso endereçado a um matemático infiel, no qual é examinado se o objeto, os princípios e as inferência da Análise Moderna são mais claramente concebidos ou mais evidentemente deduzidos do que os mistérios religiosos e Assuntos da Fé. "Retira primeiro a trave de teu próprio olho; poderás então ver claramente e retirar o cisco do olho do teu irmão"77.

ORG 2 - Não podemos nos esquecer, entretanto, de que a imagem do anjo-mulher-liberdade de seios nús que nos dá a ver Delacroix, empunhando a bandeira ažl, branca e vermelha liberdade, igualdade, fraternidade -, na qual se inspiraram todas as lutas anti-coloniais americanas, não é mais, a rigor, a imagem do anjo que embalou a revolução francesa, mas sim, a imagem de um anjo já desfigurado pela imagem napoleônica daquela revolução. O anjo de Delacroix é só mais um anjo whig travestido de mulher, um anjo-macho-patriarcal-bélico-imperialista, exatamente

\footnotetext{
73 George Berkeley (1685-1753), bispo-filósofo imaterialista irlandês que negava a existência da matéria e do mundo materialmente constituído, tal como o viam os empiristas europeus do século XVIII. Não era desta mesma natureza a oposição entre o materialismo naturalista do matemático d'Alembert e o materialismo organicista-vitalista do artista Diderot. Foi este tipo de materialismo que teve eco na constituição do paradigma morfológico ao longo do século 19 europeu, sobretudo através de pensadores como Goethe, Nietzsche, Spengler e LW.

${ }^{74}$ Davis e Hersh (1985, p. 366) viram esta crise como uma “[...] manifestação de uma discrepância duradoura entre o ideal tradicional da matemática [a que eles denominam "mito de Euclides" e a realidade da prática real da atividade matemática em um dado instante qualquer".

$75 \mathrm{O}$ anglicanismo constitui uma apropriação originalmente inglesa do cristianismo que declarou independência da igreja católica apostólica romana durante o período de regulamentação religiosa de Isabel I. Em termos das crenças que professa e práticas que realiza, esta tradição religiosa pode ser vista como um meio termo entre as duas das tradições protestantes à época emergentes no continente europeu: o luteranismo e o calvinismo. Disponível em: $<$ https://pt.wikipedia.org/wiki/Anglicanismo>. Acesso em 03 de novembro de 2020.

${ }^{76}$ Segundo Miguel (2018, p. 301-302, grifo nosso), “Com base em sua visão empírico-sensualista do conhecimento, D'Alembert via também a matemática como a mais abstrata das ciências da natureza, dotada do poder de fundamentar todas elas. Naquela época, o sistema formado pelas ciências da natureza era fundamentado nas leis da geometria euclidiana. Entretanto, d'Alembert contestou este fundacionismo geométrico e substituiu-o por um outro de natureza algébrica. Ele via a álgebra como uma língua artificial de cujas leis genéricas e abstratas poderiam ser deduzidas as leis das demais ciências explicativas da natureza. Assim, ao delegar à álgebra o poder de traduzir concisamente o suposto desejo de ordem da natureza, ele retirou o suporte físico-espacial da physis e o substituiu por um suporte linguístico. Entretanto, ainda que tivesse de fato percebido o potencial analítico fundante e mais elementar da "nova língua algébrica" para traduzir a própria geometria sintética, este potencial da "nova língua" ainda se devia, bem mais, ao seu poder de abstração empírica, isto é, ao seu poder de traduzir concisamente o suposto desejo de ordem da natureza, bem como as leis que governavam as relações espaciais dos objetos no espaço físico real".
}

77 (DAVIS \& HERSH, 1985, p. 366, grifo nosso). 
aquele anjo-colonizador-ave-de-rapina que em vez de guiar, travestiu as lutas pelo legítimo desejo de independência de todas as colônias, espalhando pelo continente americano outras repúblicas colonializadoras.

GSEU - Desenho original do Grande Selo dos Estados Unidos (1782) ${ }^{78}$.

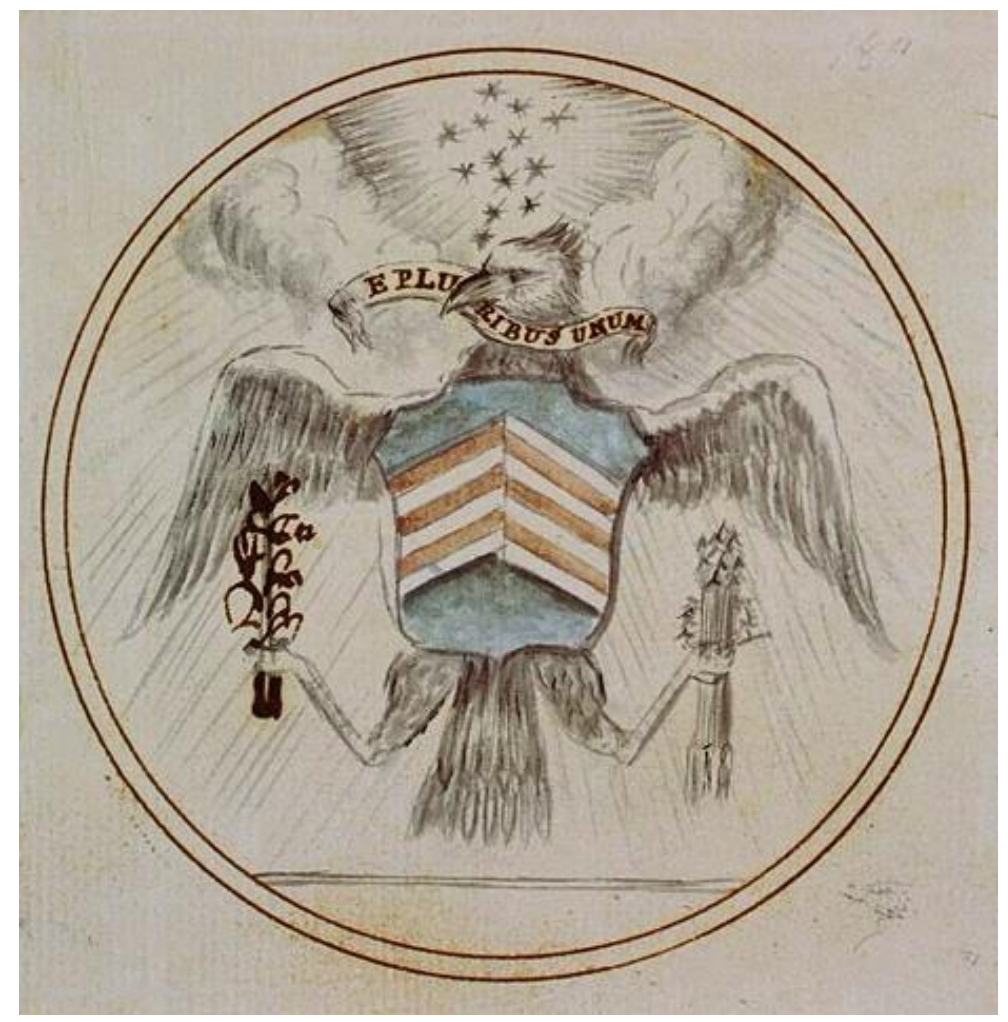

ORG 2 - O anjo travestido de mulher de Delacroix é, na verdade, um outro anjo-Frazer contra o qual não só Benjamin, mas também o LW das ORD se bateu, lançando contra ele os ventos, raios e trovões de outras tempestades, estas, sim, vindas de outros mares nunca dantes navegados ${ }^{79}$.

ORG 1 - Mas ele também não é a imagem do Angelus Novus de Klee, pois este é, de fato, um anjo novo, um anjo gödeliano indecidivel que não sabe se deseja vingar as ruínas acumuladas,

\footnotetext{
${ }^{78}$ De acordo com informações relativas à produção do Grande Selo dos Estados Unidos constantes no "National Archives and Records Administration: Washington, DC, 1986”, extraídas do site abaixo, às quais foram acrescidas outras informações extraídas do segundo site, o Congresso Continental nomeou um comitê para projetar um selo para os Estados Unidos em 4 de julho de 1776, poucas horas após a adoção da Declaração de Independência. Os membros do comitê - Benjamin Franklin, Thomas Jefferson e John Adams - apresentaram um projeto muito complicado que não foi nem rejeitado e nem aprovado pelo Congresso. No entanto, uma de suas características proeminentes - o lema "E Pluribus Unum" ("Dentre Muitos, Um") - foi mantida no projeto final que foi aprovado só em 20 de junho de 1782 após ter o projeto inicial ter concorrido com três outros. Do segundo projeto apresentado foram mantidos o ramo de oliveira, a constelação de 13 estrelas e o escudo com listras vermelhas e brancas em um campo azul. Do terceiro projeto foi mantida a águia de cabeça branca, de asas abertas, segurando 13 flechas em sua garra esquerda, simbolizando os 13 estados originais, e em sua garra direita, um ramo de oliveira, simbolizando a preferência dos Estados Unidos pela paz. Finalmente, o Secretário do Congresso Continental - Charles Thompson - fez um quarto desenho que foi revisado por William Barton, um estudante de heráldica da Filadélfia, e aprovado em 20 de junho de 1782. Fontes: (https://www.ourdocuments.gov/doc.php?flash=false\&doc=5\#>;

(https://pt.wikipedia.org/wiki/Grande Selo dos Estados Unidos). Acessos em 03 nov. 2020.

${ }^{79}$ ORG 2 faz uma alusão irônica a um verso de Os Lữiadas do poeta português Luís de Camões (1524-1580).
} 
no passado, pelos monumentos da razão e da fé ou se deseja deixar-se arrastar, pela fé d'alambertiana do vento previsivel da promessa de paraíso que sopra do futuro. O Angelus Novus não mais se vê nem homem e nem mulher, mas, tão somente, um anjo assexuado, como todos os demais anjos que anunciam profecias e nunca mais voltam a sobrevoar panoramicamente a Terra para terem que desmenti-las.

ORGS - O olho terapêutico-gramatical de LW não é um olho de anjo. É um olho que vê panoramicamente os modos como os olhos de anjos veem a história e os desconstrói, isto é, nos dá a ver como não se pode vê-la nem com os olhos do anjo de Delacroix e nem com os olhos do anjo de Klee. O olho de LW, crítico da imagem evolucionista da história, ao desconstruir a obra monumental de Frazer, deu-nos a ver a enorme sombra que o seu triunfante edifício expansionista, bélico-imperialista e colonizador projetava sobre as ruínas de seu próprio futuro.

$\mathbf{L W}^{80}$ - "Este livro foi escrito para pessoas que têm afinidade com o seu espírito. Este espírito é bem diferente daquele que informa a vasta corrente da civilização europeia $e$ americana de que todos somos parte. Aquele espírito tem expressão num movimento para adiante, em construir estruturas sempre mais amplas e mais complicadas; o outro consiste em lutar por clareza e perspicuidade em toda e qualquer estrutura. O primeiro tenta entender o mundo por meio de sua periferia - em sua variedade; o segundo, em seu centro - em sua natureza. E, portanto, o primeiro acrescenta uma construção à outra, avançando para a frente e para o alto, por assim dizer, de uma etapa para a seguinte, ao passo que o outro permanece onde está e o que tenta entender é sempre a mesma coisa".

ORGS - De fato, após a demolição terapêutica da narrativa civilizatória whig-colonizadora de Frazer, LW - como ele nos dá a ver no extrato acima do prefácio das Observações filosóficas percebeu e reprovou a base ética da imagem de civilização que ela promovia. Nessa crítica, LW novamente aciona imagens arquitetônico-visuais tanto para pôr diante de nossos olhos - "Não pense, veja!" - e desconstruir o que via como o aspecto ético-estético desagregador da civilização ocidental em ruínas - qual seja, o seu desejo desenfreado de progresso material e tecnológico, de consumo, de acúmulo de bens e fortunas e de controle determinista e fundamentalista de riscos imprevisíveis de todos os tipos -, quanto para dar visibilidade ao aspecto ético-estético agregador e instaurador de um outro tipo de civilização que estaria em luta vigilante, persistente e permanente para dissipar as névoas e, por extensão, os sofrimentos e os mal-entendidos que impediam que se visse com clareza e olho panorâmico de pássaro libertador, em quaisquer formas de vida, as conexões ilusórias e falsas que estabelecemos entre os fatos, quando lidamos com os problemas que nelas se constituem. Esta crítica ao aspecto ético-estético desagregador da civilização europeia e americana, bem como ao projeto whig-historicista que o glorifica e perpetua nos é dada a ver com clareza nas imagens arquitetônico-visuais de alguns aforismos que LW constrói para desconstruir imagem civilizatória. Neles, LW nos dá a ver a nossa cegueira, a nossa perda de visibilidade para o que está

\footnotetext{
${ }^{80}$ Prefácio ao livro que reúne anotações feitas por LW em diferentes épocas, postumamente publicado sob o título Observações Filosóficas (LW, 2005, grifo nosso).
} 
manifestamente estampado na superfície desse edifício civilizatório e claramente exposto à nossa visão:

$\mathbf{L W}^{81}$ - "As pessoas que perguntam constantemente "porquê?" $S \tilde{A O} C O M O$ os turistas que estão diante de um edifício a ler um guia e estão tão ocupados com a leitura histórica da sua construção, que isso os impede de ver o edifício".

$\mathbf{L W}^{82}$ - "Cada uma das frases que escrevo procura exprimir tudo, isto é, a mesma coisa repetidas vezes; é como se elas fossem simplesmente visões de um mesmo objeto, obtidas de ângulos diferentes. Poderia dizer: se o lugar a que pretendo chegar só se pudesse alcançar por meio de uma escada, desistiria de tentar lá chegar. Pois o lugar a que de fato tenho de chegar é um lugar em que já me devo encontrar. Tudo aquilo que se pode alcançar com uma escada não me interessa".

ORGS - A imagem representacionista da linguagem vista como espelho lógico de um mundo logicamente estruturado havia sido o olhar ético-estético em perspectiva cônica do pintor-LW que colocava o sujeito no limite do mundo, lá onde a linha do horizonte, limite entre a linguagem e o mundo, define o que pode ou não ser dito, visto, pintado significativamente. Mundo plano. Espelho plano. Lógica clássica. Olho que só precisa do espelho plano de uma lógica plana apenas potente para descrever um mundo plano. O LW terapeuta crítico de Frazer precisou quebrar o espelho plano incolor, cristalino com o qual o olho-gramatical de Frazer via o mundo e passar a vê-lo com o olho gramatical de pássaro, não, porém, com o olho de águia, de ave de rapina, carnívora, de garras fortes e poderosas; não também com olho de gavião que pega, mata e come; não com o olho de águia de bico curvo, afiado, visão telescópica agudíssima, muitíssimo superior à do olho humano cônico. Pois, as aves de rapina haviam roubado o seu poder da palavra rapina de raiz latina que significa raptar. Palavra e ave haviam sido planejadas para raptar... de tudo: velos de ouro, ouro, especiarias, paus-brasis, ramos dourados de trigo, eldorados, pintores, geômetras, estrategistas, geometrias planas, tridimensionais, $\mathrm{n}$-dimensionais, euclidianas, projetivas, topológicas, não-euclidianas, Euclides, Leonardos, Descartes, Desargues, Pascal, Poncelet, Monge...

ORGS - Um tipo particular de perspectiva cônica - uma projeção criada por pintores e arquitetos do Renascimento com o propósito de se representar, em uma tela plana, e com o grau máximo de fidelidade possível, cenas tridimensionais do espaço real, ou seja, aquilo que olho "de fato" vê tal como vêe-, a perspectiva cavaleira não corresponde à visão real que temos dos objetos, por ter ela como propósito satisfazer o desejo de se representá-los retificandoos segundo o olho gramatical do geômetra ou o olho gramatical do estrategista militar. Diferentemente do olho gramatical deste último, o olho gramatical genérico e abstrato do geômetra não tem preferência do local a situar-se para de lá observar a sua "paisagem", igualmente genérica e abstrata. Para o olho gramatical do geômetra, toda perspectiva é uma boa perspectiva. Já o olho gramatical do estrategista militar anseia por inspecionar a paisagem ao

${ }^{81}$ (LW, 2000, p. 65, destaques nossos em maiúsculas e itálicos).

82 (LW, 2000, p. 21, grifo nosso). 
redor, situando-se, portanto, muito acima da linha de terra ${ }^{83}$ para de lá lançar o seu olhar de águia, razão pela qual uma perspectiva cônica que assuma essa característica de sobrevoo de pássaro - tais como aquelas que o olho vê nos desenhos da paisagem feitos pelas patrulhas napoleônicas no século XIX, provavelmente inspirados em práticas análogas realizadas no século XVI - é denominada perspectiva militar. No século XVI, na forma de vida bélico-militar europeia e, particularmente, no campo de atividade da construção arquitetônico-militar, cavalier era o nome dado ao local mais alto de uma fortificação e de onde se poderia ter uma visão telescópico-panorâmica de toda a paisagem ao redor, bem como da própria fortificação como um todo ${ }^{84}$. É provável que o nome perspectiva cavaleira tenha se inspirado nesse tipo de edifício arquitetônico-panóptico. O olho gramatical panóptico-cavalier-de-ave-de-rapina da perspectiva cavaleira foi apenas a ampliação funcional-qualitativa, proporcionada pelo olho-telescópico de Galileu, do campo de visibilidade do olho-bala-balístico-quantitativo do "canhão-pólvora-f(x)" que havia deixado em ruínas os castelos medievais e que tentava, desde então, reparar a "fundação fundacionista" repleta de rachaduras do pragmático edifício arquitetônico revolucionário do cálculo diferencial e integral.

\section{O ver como o olho gramatical morfológico vê}

ORGS - Antes, porém, do anjo de Klee lançar o seu olhar de espanto para o projeto civilizatório imperialista-colonizador-iluminista, em plena ascensão, e antes de Benjamin prenunciar as suas ruínas estampadas na Paris capital do século XIX, alguns artistas alemães, românticos mas não ingênuos, começaram a olhar para tal projeto com o olho gramatical Sturm und Drang ${ }^{85}$. Não pensem, vejam!

ORGS - Quando o olho em perspectiva cônica de Caspar Friedrich, situado no mesmo plano da linha de terra da paisagem, olha frontalmente a linha do horizonte entardecendo, o que ele vê não é senão um flash constrastante de luzes e sombras que dá visibilidade a uma abadia em ruínas e a troncos esqueléticos retorcidos de carvalhos secos e agonizantes sob uma paisagem desértica, melancólica e sem vida. É esta paisagem que nos é dada a ver em Adabia no carvalhal $^{86}$. Ela nos remete, num lance súbito de visão - Não pense, veja! -, a uma reação crítica impiedosa, de cunho místico-fideísta, ao desejo normatizador, normalizador, padronizador, racionalista, universalizante, anti-religioso, anti-metafísico e cientificista do Zeitgeist normativo franco-iluminista do século 18, amplamente disseminado na Alemanha, no início do século 19.

\footnotetext{
${ }^{83}$ Em geometria projetiva, denomina-se linha do horizonte (LH) ou linha de fuga (LF) a linha imaginária que determina a 'altura' ou distância dos olhos de um observador em relação à linha de terra (LT), isto é, e relação à reta determinada pela intersecção entre o plano de projeção ou de representação e o plano no qual se situa a paisagem ou o objeto a ser representado. ${ }^{84}$ Fontes: (VELOSO, 2000, p. 144; 157; 160); (https://pt.wikipedia.org/wiki/Perspectiva_cavaleira).

85 Sturm und Drang (tempestade e impeto) foi um movimento literário do romantismo alemão, que ocorreu no período entre 1760 e 1780. Sua principal característica foi a de oposição ao racionalismo do século XVIII, através de uma pauta que enaltecia a poesia performativa de natureza mística, selvagem, espontânea e quase primitiva. Disponível em: (https://pt.wikipedia.org/wiki/Sturm_und_Drang). Acesso em 05 de novembro de 2020.

86 Óleo sobre tela do pintor e escultor alemão Caspar David Friedrich (1774-1840) intitulada Abadia no carvalhal (1810). Disponível em:

(https://pt.wikipedia.org/wiki/Caspar_David_Friedrich\#/media/Ficheiro:Abtei_im_Eichwald_(C_D_Friedrich).jpg). Acesso em 05 de novembro de 2020.
} 


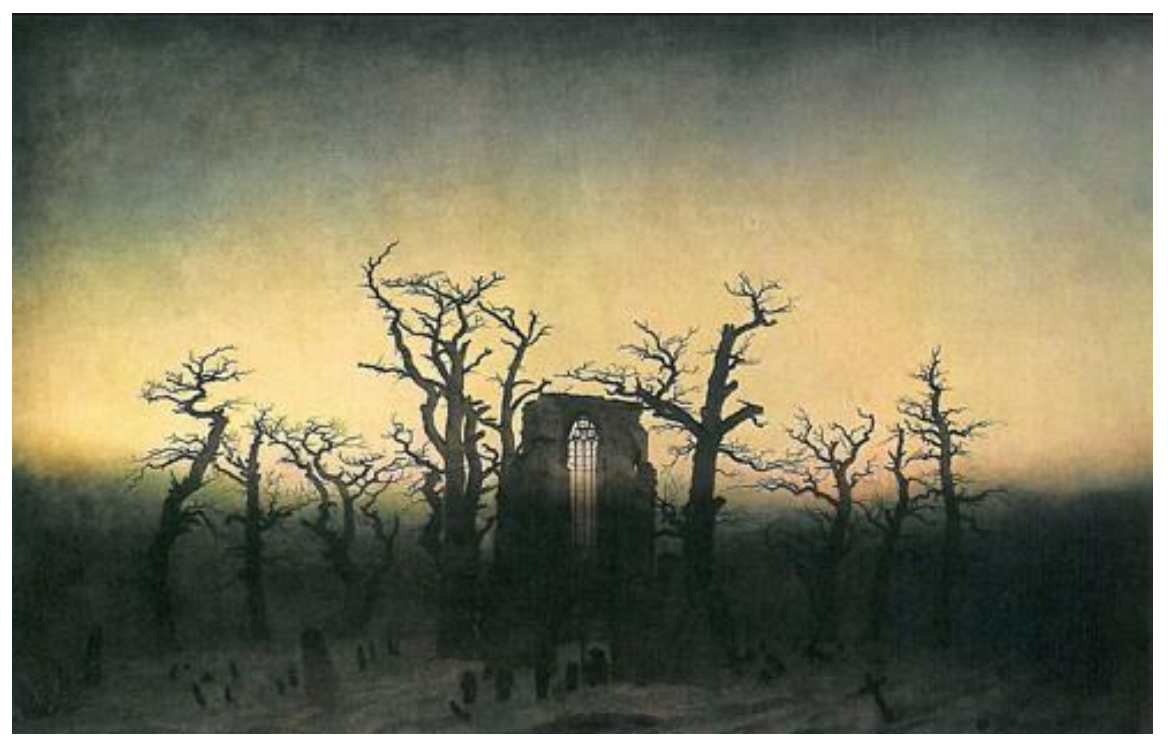

ORGS - Contrastando com olhar gramatical em perspectiva cônica frontal coplanar à paisagem que a Abadia no carvalhal dá a ver aos olhos do observador - em que a janela da abadia em ruína ocupa o centro da cena e o ponto médio da linha do horizonte -, o olho gramatical do viajante de "O viajante sobre o mar de névoa" 87 , de costas para o observador e situado no topo-cavalier de uma montanha bem acima da paisagem que observa, lança o seu olhar de pássaro diretamente para a linha do horizonte que se dissolve indistinta no precipício revolto do mar de névoa que se confunde com o pano de fundo celeste, igualmente nublado, que completa a paisagem. Não pense, veja! O viajante contemplativo-reflexivo de Friedrich é o oposto do flâneur baudelaireano de Benjamin a observar alienado as fantasmagorias que não o assombram. Do alto do seu cavalier, o seu olhar de pássaro-desejode-visão-clara-e-distinta viaja em perspectiva cavaleira por sobre as ruínas da paisagem ocultas pela névoa. O que nos dá a ver com o seu olho de pássaro o olho gramatical morfológico? O que ele nos dá a ver são organismos, organizações, sistemas, holismos, formas, vidas, formas de vida, metamorfismos, isomorfismos, interações, estruturas, invariâncias, padrões, fisiognomias, analogias, semelhanças, diferenças, afinidades ...

87 Óleo sobre tela do pintor e escultor alemão Caspar David Friedrich (1774-1840) intitulada O viajante sobre o mar de névoa (1818). Disponível em:

(https://pt.wikipedia.org/wiki/Caspar_David_Friedrich\#/media/Ficheiro:Caspar_David_Friedrich_-

_Wanderer_above_the_sea_of_fog.jpg). Site acessado em 05 de novembro de 2020. 


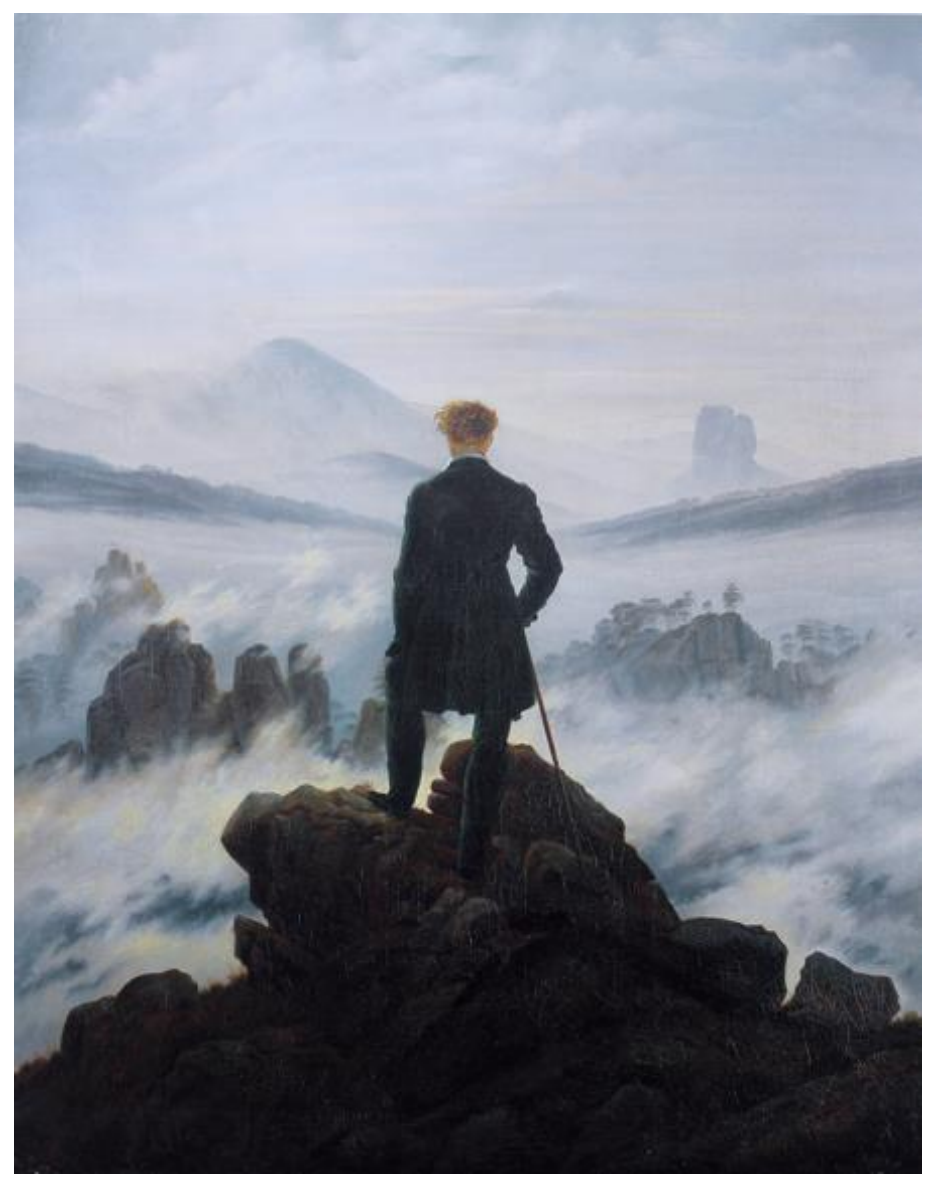

$\mathbf{R H}^{88}$ - "Em 14 de outubro de 1806, travou-se a batalha de Iena, perdida pelos alemães, e em seguida o exército francês entrou em Weimar. Ocorreram pilhagens e outros inconvenientes, a casa de Goethe foi invadida, e parece que o autor de Fausto foi salvo de maus-tratos pela interposição corajosa de sua Gretchen, que expulsou os soldados. No dia seguinte, Napoleão chegou à cidade e teve início uma ocupação militar organizada. Nessas circunstâncias e também, sem dúvida, inspirado a renovar a afeição pelo comportamento corajoso de Christiane, Goethe decidiu finalmente que lhe devia dar a segurança do matrimônio e tomou providências imediatas. Não há nenhuma razão para pensar - ao contrário, há todos os motivos para duvidar — que teria dado esse passo se não fosse forçado a dá-lo quase literalmente pela ponta de uma baioneta”.

ORG 2 - É... as afinidades são, de fato, eletivas...

ORG 3 - De acordo! Foi Morfeu quem, assumindo a forma de Napoleão, decidiu pela nova forma que assumiria a vida de Goethe...

ORG ${ }^{89}$ - A palavra grega morphéus (morfeu) significa, literalmente, aquele que molda a forma. $\mathrm{Na}$ mitologia grega, ele é o deus do sonho e possui muitos irmãos, os oniros, os quais, segundo Homero, na Odisseia, moravam na terra dos sonhos passados, lá perto de onde os

88 Passagem da Introdução por R. J. Hollingdale ao romance de Goethe intitulado As afinidades eletivas (GOETHE, 1971, p. 1).

${ }^{89}$ Pintura em óleo sobre tela do pintor neoclássico francês Pierre-Narcisse Guérin (1774-1833) intitulada Morfeu e Íris (1811). Disponível em: (https://pt.wikipedia.org/wiki/Morfeu);

(https://pt.wikipedia.org/wiki/Tânato). Acesso em 05 de novembro de 2020. 
espíritos dos mortos são levados para o reino de Hades, o deus da morte. Dotado de grandes asas que batem sem fazer barulho, Morfeu tem o poder de assumir qualquer forma bumana e manifestar-se nos sonhos de humanos. Já Íris era a mensageira dos deuses na Terra. Transformava-se num arco-Íris quando algo tivesse que ser dito aos humanos. Íris e Hermes se amaram por muito tempo, mas ela decidiu dele se separar após ele tê-la traído com Afrodite. Elegeu, então, Zéfiro, o deus do vento, como seu novo amante, casando-se com ele.

ORG 2 - Não pensem, vejam! Nesta imagem de Morfeu e Íris de Guérin foi Morfeu quem elegen sonhar com Íris ou Íris quem elegen sonhar com Morfeu?

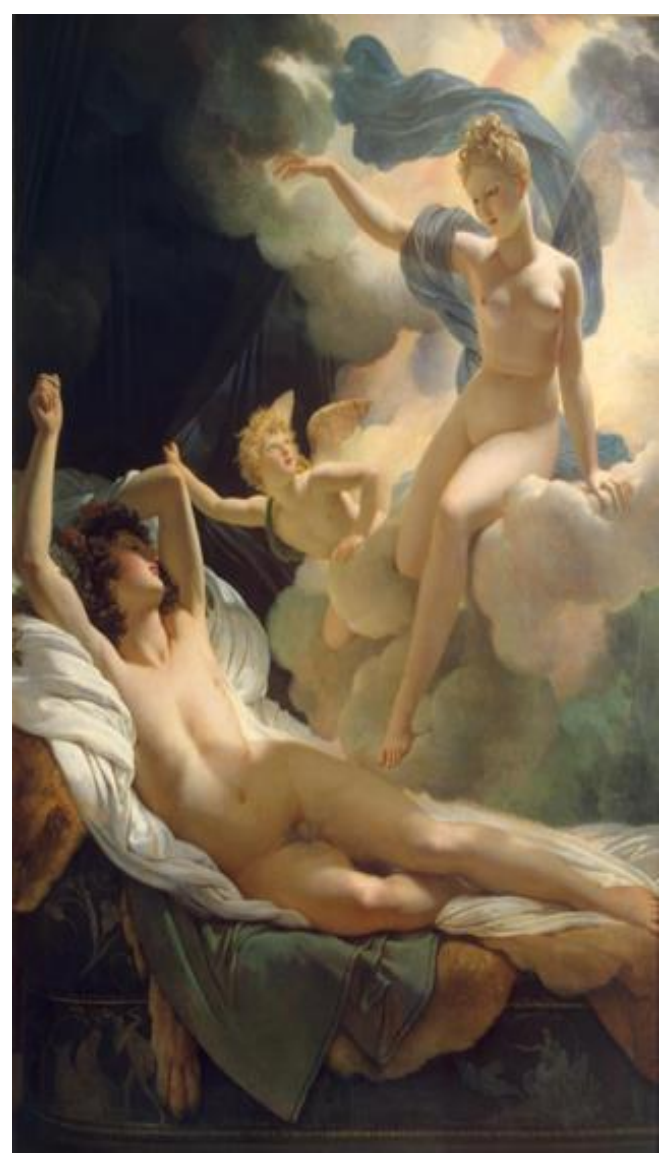

$\mathbf{V H}^{90}$ - "Morfologia é um conceito geral. Em Biologia, ela consiste na análise do tamanho, forma e estrutura interna (e relações entre eles) de animais, plantas e microorganismos. Em Linguística, consiste na análise da estrutura interna das formas das palavras. Em ciência dos materiais, ela se centra no estudo da forma, tamanho, textura e das fases termodinamicamente distintas dos objetos físicos. Já no domínio do processamento de imagens e de sinais, a morfologia matemática consiste na construção de modelos teóricos baseados em teoria das matrizes visando ao processamento de sinais/imagens, segmentação etc. A morfologia é uma teoria voltada para a análise de estruturas planas e espaciais; é adequada para analisar a forma de objetos; é baseada em uma teoria de conjuntos, álgebra integral e álgebra de reticulados; é bem-sucedida devido a um

90 (HLAVÁČ, s/d, p. 1-2). 
formalismo matemático simples, que abre um caminho para ferramentas poderosas de análise de imagens. A ideia-chave da análise morfológica é extrair conhecimento da relação entre uma imagem e uma sonda simples e pequena (chamada de elemento estruturante), que é uma forma pré-definida. É verificado em cada pixel como esta forma ganha ou perde as formas locais na imagem".

ORG 1 - Em um campo da matemática denominado geometria das transformações, semelhança e afinidade são conceitos diferentes. Dois polígonos se dizem semelhantes quando seus ângulos internos correspondentes têm a mesma medida, o mesmo não acontecendo com os seus lados correspondentes. Dizem-se afins quando todos os pares de lados paralelos de um deles permanecem também paralelos no outro. Assim, uma transformação por semelhança de um polígono $\mathrm{A}$ em um polígono B preserva tanto o paralelismo dos lados quanto as medidas dos ângulos internos de ambos, ao passo que uma transformação por afinidade entre ambos só preserva o paralelismo dos seus lados.

ORG 2 - Não pensem, vejam!
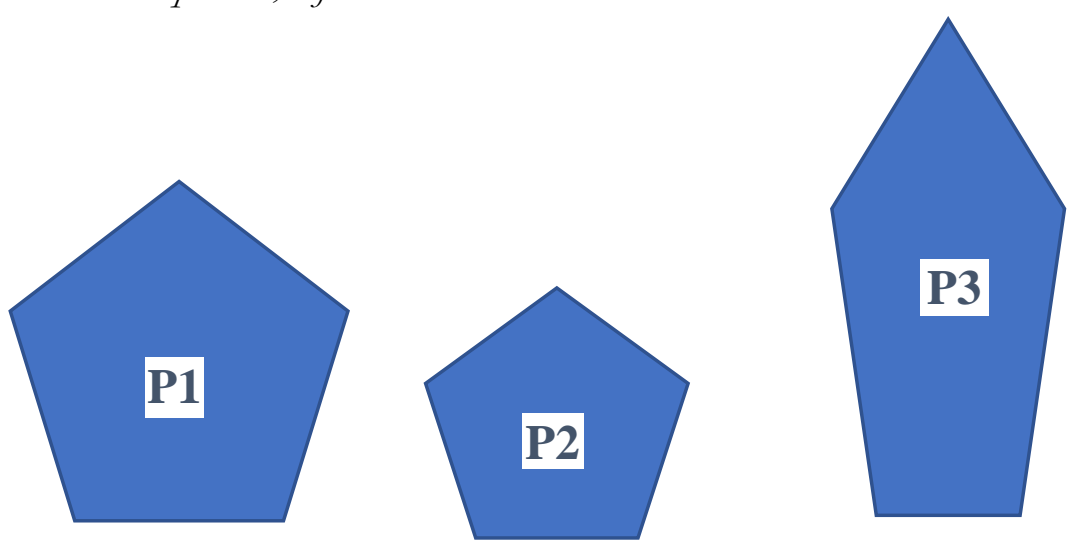

ORG 2 - Entre os pentágonos P1 e P2 existe semelhança, parentesco, semelhanças de família; eles possuem a mesma fisiognomia. Já entre os pentágonos P2 e P3 existe apenas afinidade.

$\mathbf{J A}^{91}$ - "Fisiognomia era o nome que se deu a uma antiga forma de estudo que tentava desvendar o caráter de uma pessoa pelas suas expressões faciais. Ao longo de toda a sua obra, LW remete a uma interrelação entre significação, visão de aspecto, fisiognomia e expressão. [...] No Tractatus Logico-Philosophicus, uma fisiognomia pode ser concebida precisamente como uma marca em que um certo tipo de ambiguidade estética é uma possibilidade perceptiva. Já [...] por volta de 1946, vemos, no uso de uma palavra, também uma fisiognomia, [...] o que testemunha a ideia da fisiognomia orientando as noções de limite, de variabilidade e de multiplicidade, quando todo esse jogo de linguagem está relacionado à compreensão de fenômenos tão simples como um sorriso".

${ }^{91}$ (ALMEIDA, in WITTGENSTEIN, s/d, Nota 160, p. 338-339, grifo nosso). 
$\mathbf{L W}^{92}$ - "O que eu faço é a morfologia do uso de uma expressão. Eu mostro que ela tem usos com os quais vocês nunca sonharam. Em filosofia sentimo-nos forçados a olhar para um conceito de um certo modo. O que eu faço é sugerir, ou mesmo inventar, outros modos de olhar para ele. Eu sugiro possibilidades nas quais vocês não haviam previamente pensado. Pensavam que havia apenas uma possibilidade ou duas no máximo. Mas eu faço vocês pensarem em outras possibilidades. Além disso, faço vocês verem que seria absurdo esperar que o conceito se conformasse a essas possibilidades restritas. Assim, a cãimbra mental que vocês sentem é aliviada e vocês têm a liberdade para examinar o campo de uso de uma expressão, bem como para descrever os seus diferentes usos".

$\mathbf{M H}^{93}$ - "De las reflexiones anteriores concluye Edwards que toda la obra de Wittgenstein, tanto en el Tractatus como en los escritos posteriores, es "una acción ética" entendida como una ayuda para vivir, el señalar hacia una nueva sensibilidad y una forma de vida que le corresponda. En oposición a la ciencia y al pensamiento literalizante de la metafísica, esta nueva sensibilidad, más allá de la ética, expresa un "compromiso religioso, que trata el mundo como un milagro, como objeto de amor y no de voluntad" y nos lleva a "ver el misterio como su significado". Wittgenstein, al igual que Kierkegaard, sería un profeta y un evangelista. Fann parece suscribir también la idea de comprender el método de Wittgenstein desde la estética, pero en lugar de una analogía, postula sencillamente la identificación entre ambos. Después de afirmar que la más importante contribución de Wittgenstein a la filosofía moderna es su método, lo caracteriza de la siguiente manera: $S u$ método, por supuesto, no puede seguirse como una receta o fórmula, más bien se trata de un arte. Wittgenstein era, por encima de todo, un artista que creó un nuevo estilo de pensamiento."

ORGS - "Em vão tentamos expressar a essência de uma coisa. Percebemos efeitos, e uma história completa desses efeitos haveria de abranger certamente a essência daquela coisa. Inutilmente nos esforçamos para descrever o caráter de um ser humano; antes, apresentamos suas ações, seus feitos, e uma imagem do caráter nos ocorrerá" ${ }^{94}$. Marco Giannotti interpreta esta fala de Goethe no prefácio do seu livro Doutrina das cores dizendo que "somente pelas ações podemos conhecer o caráter de uma pessoa. A ação se torna a medida do homem no mundo. Se as palavras se tornaram opacas e turvas, se toda teoria é "cinza" e a "árvore dourada da vida, verde", ação e vida resgatam o sentido das coisas. Mesmo para a filosofia, a vida adquire um novo sentido": "Nosso pensamento filosófico não significa nada e não tem o menor conteúdo. - Nada tem valor e significado incondicionados, a não ser a vida; todo o demais, pensamento, invenção e saber, só tem valor na medida em que de algum modo se refere ao que é vivo, parte dele e visa refluir para ele" ${ }^{95}$.

\footnotetext{
${ }^{92}$ Fala de LW em uma de suas aulas ministradas em Cambridge, entre 1946 e 1947, sobre filosofía da psicologia, extraída da referencia (MALCOLM, 2001, p. 43).

93 (HOLGUÍN, 2003, p. 132-133).

${ }_{94}$ Fala de Marco Giannotti na introdução que faz à sua tradução para o português da obra Doutrina das cores de Goethe (GOETHE, 1993, p. 21, grifo nosso).

${ }^{95}$ Estas são palavras do filósofo alemão J. G. Fichte, citadas por Marco Giannotti na introdução que faz à sua tradução para o português da obra Doutrina das cores de Goethe (GOETHE, 1993, p. 21).
} 
JG - "O que é, pois, a ciência? / É apenas força da vida. / Vocês não engendram a vida. / A vida deve antes dar a vida"

$\mathbf{A M}^{97}$ - "Para Diderot, a passagem do mundo inorgânico ao mundo orgânico era vista como um processo cíclico contínuo de transformações orgânicas da matéria. Segundo Marilena Chauî", "Diderot não interpreta a natureza como um sistema puramente físico (como os demais materialistas de sua época), mas como um sistema orgânico e biológico, dentro do qual é fundamental a hipótese de sensibilidade da matéria. Tanto a matéria inorgânica quanto a organizada, isto é, os seres vivos, são vistas como capazes de sensibilidade. Postulando o movimento e a sensibilidade como inerentes a toda matéria, Diderot supunha que se poderia explicar toda a cadeia de fenômenos naturais, tanto físicos quanto mentais. Tudo o que a natureza contém seria produto de matéria em movimento, submetida a processos de fermentação produzidos pelo calor". Seguindo esta linha interpretativa, pensamos que a filosofia materialista de Diderot poderia melhor ser vista como um naturalismo vitalista que propõe uma solução de continuidade entre natureza e cultura humana, bem como entre natureza, pensamento, sensibilidade e subjetividade humanas, uma vez que Diderot não vê a natureza meramente como physis inorgânica, mas também como um organismo dotado de sensibilidade, movimento, transformação e vida evolutiva" 99 . De fato, "Diderot era adepto do vitalismo da Escola de Montpellier. Mas ele defendia um vitalismo materialista de natureza organicista de acordo com o qual a noção de vida se afastava tanto daquela na qual a inseria a analogia do universo como máquina, instaurada pelo mecanicismo cartesiano, quanto da visão idealista sobrenatural instaurada pelo cristianismo".

VVJ"100 - "Em Fisiologia, vida é o oposto da morte, que é a destruição total dos órgãos vitais, sem que estes possam se restabelecer, de sorte que o mínimo de vida é aquele do qual nada se pode privar sem que advenha a morte. Vê-se que, nesse estado delicado, é difícil distinguir o vivo do morto; mas, tomando-se aqui o nome vida na acepção comum, defino-a como um movimento contínuo de sólidos e fluidos em todo corpo animado. [...] É suficiente dizer aqui que esse movimento resulta da dissipação das partes aquosas, móveis, fluidas; e que todo o resto se torna impróprio para a circulação, e obstrui os vasos mesmos. [...] A Fisiologia demonstra que a máquina se destrói a si mesma por nuances, sem que se possa impedi-lo por qualquer remédio que seja".

$\mathbf{A M}^{101}$ - "Na crítica que Lênin dirige ao vitalismo materialista-naturalista-organicista de Diderot é possível situar, de certo modo, em que medida a filosofia terapêutica de Wittgenstein nem materialista, nem vitalista - se afasta tanto da filosofia vitalista de Goethe e de outros pensadores do idealismo alemão, quanto da filosofia do materialismo histórico-dialético.

\footnotetext{
${ }^{96}$ Aforismo de Goethe contido em sua obra Zabme Xenien e citado por Marco Giannotti na introdução que faz à sua tradução para o português da obra Doutrina das cores de Goethe (GOETHE, 1993, p. 20).

97 (MIGUEL, 2018, Nota 13, p. 303, grifo nosso).

98 (CHAUÍ, in DIDEROT, 1979, p. 20-21).

99 (MIGUEL, 2018, Nota 9, p. 302).

100 É esta a imagem que Jacourt faz da vida, no verbete "vida" que aparece no Volume 17 da Enciclopédia, inserido no campo da Fisiologia (DIDEROT; D’ALEMBERT. Ciências da Natureza, v. 3, p, 310, 2015, itálico nosso).

101 (MIGUEL, 2018, p. 307, gifo nosso).
} 
Acusando Diderot de ser "um materialista ateu, com ideias dialéticas profundas, mas metafísico", e censurando-o por ter postulado um "misterioso impulso vital inerente à natureza" para justificar a passagem da matéria sensível ao pensamento racional, Lênin acreditava que, um dia, uma nova teoria da matéria iria "explicar cientificamente" tal passagem, isto é, explicar como os humanos se tornariam propriamente humanos: “[...] falta ainda investigar e investigar de que maneira a matéria que pretensamente não tem quaisquer sensações se relaciona com a matéria composta dos mesmos átomos (ou elétrons) e que ao mesmo tempo possui a capacidade claramente expressa de sentir. O materialismo coloca claramente a questão ainda não resolvida, e deste modo incita à sua resolução, incita a novas investigações experimentais" ${ }^{102}$. Como se vê, Lênin mantinha uma dupla fé: fé na necessidade de explicar e fé na cientificidade e na materialidade da explicação, ainda que o próprio Marx houvesse dito em Miséria da filosofia - que termina com o seguinte aforismo de Jorge Sand: "Lutar ou morrer; a luta sangrenta ou o nada. Eis o dilema inexorável"103 - que não se tratava mais de explicar a vida ou as formas de vida, mas sim, transformá-las. Marx sabia que revoluções não dependiam de explicações - científicas ou não - do modo como a natureza, a matéria ou a sociedade se organizam e operam. LW disse coisa parecida no aforismo: "Se queremos lutar, lutemos! Se queremos ter esperança, tenhamos esperança! Podemos lutar, ter esperança e até mesmo acreditar, mas sem acreditar cientificamente" ${ }^{\text {"104. }}$

ORGS - Neste aforismo, LW não está adotando um ponto de vista negacionista da ciência, como o que tem se manifestado entre nós, nos últimos anos, mas sim um ponto de vista crítico em relação ao cientificismo, isto é, ao desejo manifesto por muitos cientistas de sua época de estender as análises baseadas no método empírico-verificacionista a domínios da vida comunitária pública ou privada nos quais os métodos ditos científicos nada têm a fazer ou a contribuir. Foi esta uma das críticas que LW remeteu a Frazer, mais propriamente, ao desejo de Frazer de explicar cientificamente e submeter ao crivo da verificação empírica - condenando-as como metafísicas, dogmáticas, falsas, bárbaras, selvagens etc. - as práticas simbólico-ritualistas e religiosas de diferentes povos. Sob esta perspectiva, também seria criticável o desejo ou a crença de Lênin de esperar que um dia a ciência pudesse vir a explicar a passagem da matéria inanimada para a matéria sensível, isto é, de explicar a origem da própria vida, daquilo que Diderot e os vitalistas de todas as épocas denominavam "impulso vital”, algo que eles se contentavam em, simplesmente, depositar fé, acreditar. Sob este aspecto, poderíamos dizer que Lênin se mostrava tão cientificista quanto Frazer.

$\mathbf{A M \& C V} \mathbf{C V}^{105}$ - "Houve um tempo em que a morfologia dos seres vivos não era explicada pela sua derivação da morfologia dos seres inertes, inorgânicos. Talvez, porque, postular um laço de continuidade entre essas duas formas de vida seria rebaixar o humano a níveis supostamente inferiores de vida. - Pelo menos tem sido esta, desde tempos remotos, a opção exclusiva das teorias científicas organicistas de explicação da emergência das formas

102 (LÊNIN, 1982, p. 35, grifo nosso).

103 (MARX, 1976, p. 166).

104 (LW, 2000, p. 92).

105 (MIGUEL \& VIANNA, 2020, p. 8-10). 
de vida, qual seja, distinguindo-as das formas de ser dos seres ditos inertes, inorgânicos. [...] - Ainda que cada vez mais essas explicações venham contribuindo para tornar indistinta essa fronteira. Pasteur sugeriu não serem as células, isto é, as moléculas da vida, contrariamente às moléculas do mundo mineral, assimiláveis às suas imagens em um espelho. - O que ele quis dizer com isso? - Pense, por exemplo, no DNA, um composto orgânico cujas moléculas orientam o desenvolvimento de todos os seres vivos e também alguns tipos de vírus. A forma da molécula de DNA assemelha-se a uma hélice dupla voltada para a direita, mas a sua imagem num espelho aparece como uma hélice dupla voltada para a esquerda. Já as moléculas simétricas dos minerais não gozam dessa propriedade e as moléculas de todo ser que pode ser fabricado com moléculas simétricas minerais continuam sendo simétricas. - Continua sendo um critério normativo, ainda que empiricamente observável, para se distinguir vida de não vida. - E aqui, a norma natural parece ser a de que a vida teria sido levada a optar por formas assimétricas orientadas para a direita, em nítido contraste à simetria dos cristais líquidos. - Parece que a vida prefere a desordem à ordem... - Mais radicalmente, alguns cientistas vêm falando dos seres vivos como estruturas dissipativas produzidas através de processos aleatórios. Foi o matemático inglês Allan Turing, em artigo de 1952 intitulado As bases quimicas da morfogênese, que conjecturou que as formas vivas resultariam da associação entre reação química e difusão de matéria. Ilya Prigogine, na teoria das estruturas dissipativas, usa essa associação. - E o que eles querem dizer com isso? - Que vida é algo que participa da termodinâmica do irreversível, isto é, de reações químicas que se processam de modo irreversível em ambientes fluidos. Pense, por exemplo, numa gota de tinta rubra dispersando-se progressivamente na água contida num copo. Depois de um certo tempo, a cor da água ficará completamente uniforme, indicando que a tinta não mais se concentra em apenas alguns locais da água. Entretanto, em reações num ambiente fluido não dissipativo, ocorreria exatamente o oposto desse tipo de distribuição uniforme da tinta na água. - Você está querendo dizer que, visualmente, a morfogênese de uma vida seria um processo de distribuição não uniforme, um processo caótico que não poderia ser visualmente descrito por uma curva normal? - O que estou querendo destacar é o poder criativo dos processos aleatórios na produção de vida de diferentes formas de vida. - Mas dizer isso não é o mesmo que dizer que vidas se produzem aleatoriamente? - É o mesmo que dizer que vidas se produzem no caos do acaso".

ORG 1 - Sem reivindicar cientificidade e fazendo uso de um gênero textual descritivo e extremamente detalhista, em $A$ metamorfose das plantas, Goethe, embora mantendo fidelidade ao paradigma morfológico-analógico-vitalista, quebra o espelho da natureza, fazendo avançar uma teoria organicista acerca da metamorfose das plantas, em explícito contraste com aquela que havia sido defendida por Lineu em seu Systema Naturae (Sistema da Natureza):

$\mathbf{J G}^{106}$ - "Tentamos explicar a identidade interior dos diferentes elementos da planta, desenvolvidos um após outro, com base na máxima divergência das formas exteriores".

106 (GOETHE, 1997, p. 23). 
ORG 2 - O Goethe cientista parece incorrer no mesmo erro cientificista que LW acusava em Frazer, qual seja, o desejo de explicar, de se fazer avançar teorias explicativas.

ORG 1 - Concordo! Penso, porém, que essa explicação que fornece Goethe pode ser vista como uma explicaşão estruturalista típica, muito antes do advento do próprio estruturalismo linguístico, dado que ela consiste no desejo de se ver invariância para além das transformações, das metamorfoses, em se ver regularidade ou unidade para além da diversidade. E, para além da diversidade, um invariante natural oculto, uma força vital ${ }^{107}$.

ORG 2 - Não só a explicação é tipicamente estruturalista, como também temos um exemplo de que Goethe lançou mão de um método que poderíamos denominar morfológicoanalógico, mas de fisiognomia tipicamente estruturalista para identificar, com sucesso, o corpo do filósofo Schiller, em um ossuário repleto de caveiras de outros corpos, reconhecendo o crânio do filósofo pelo alinhamento horizontal dos dentes superiores. E isso só foi possível porque a metamorfose orgânico-topológica por que passam os corpos humanos ao longo da vida, bem como após a morte, deixa invariante certos traços diferenciais individuais para além de todas as semelhanças ou características comuns existentes entre eles.

ORG 3 - Acrescento que o Goethe-poeta, replicando o Goethe-cientista, deu-nos a ver poeticamente uma imagem do seu método morfológico-analogico-estruturalista através dos seguintes versos de Ao contemplar o crânio de Schiller.

$\mathbf{J G}^{108}$ - "Foi ao ver na massa inerte / uma forma de valor tão inconteste / que na fria sala úmida, angustiante, / eu, já livre e acalorado, reanimei-me, / qual se a morte para vida fosse fonte. / Com tal forma misteriosa encantei-me! / Traço pensado de Deus, que se conserva! / [...] Que mais traz, na vida, ao homem regozijo / do que Deus, em sua essência, revelar-se? / Na matéria sublimando-se em espírito, / e em firme o que é divino conservar-se".

$\mathbf{E T}^{109}$ - "Com o método de Lineu para sistematizar a botânica a pesquisa contemporânea não progrediu muito. O que ficon ainda por faz̧er era uma ordenação sob o ponto de vista das relações de parentesco. Os esforços de Goethe se dirigiram para achar aquilo que seria fundamental em todas as plantas, sem distinção, e assim ele descobriu a lei da metamorfose das plantas".

$\mathbf{L W}^{110}$ - "E assim o coro aponta para uma lei secreta", poder-se-ia dizer da coletânea de fatos frazereana. Esta lei, esta ideia, eu posso exprimir (apresentar) mediante uma hipótese evolutiva, ou também, em analogia com o esquema de uma planta, pelo esquema de uma cerimônia religiosa, ou tão somente pelo agrupamento dos materiais factuais, numa apresentação panorâmica".

ORG 3 - Nessa passagem das Observações sobre o Ramo Dourado de Fražer, LW apresenta uma crítica ao método frazereano, isto é, ao modo de se investigar e aos propósitos visados por uma investigação historiográfica evolutivo-linear whig. Essa crítica não diz respeito

\footnotetext{
107 (MIGUEL, 2016a, p. 533-534).

108 (GOETHE, 1997, p. 38, grifo nosso). A tradução completa do poema para o português foi feita por Jacira Cardoso.

109 (TOLEDO, 2007, p. 35, grifo nosso).

110 (LW, 2007, p. 200, grifo nosso).
} 
unicamente ao fato de tal método ser evolutivo e linear, mas também, e sobretudo, por ser hipotético.

ORG 1 - Crítica idêntica faz também LW ao método analógico orgânico-vegetalcerimonial de Goethe, que também se deixa orientar por uma hipótese, não mais evolutivolinear, mas morfológica ou fisiognômica.

ORG 2 - Eu concordo com você, mas parece que LW não vê como morfológicofisiognômico o método de Frazer. O que estaria ele querendo significar quando vê analogia entre o método de Goethe e o "esquema de uma cerimônia religiosa"? Seria o agir orientado por uma fé cega numa lei secreta, no impulso natural, em deuses?

ORG 1 - Caso seja, enquanto o agir orientado pela hipótese evolutiva seria um agir teleológico d'alembertiano que coloca a fé e a certeza da luz no por vir, no que virá, o agir morfológicocerimonial seria um agir goetheano que colocaria a fé e a certeza da luz, do bem, do belo, da verdade e da norma correta no que já está posto, no que já é e que só nos dá a ver mediante a observação atenta, obediente, paciente e descritiva da metamorfose de uma forma - no caso de Goethe, o de uma planta - que se processa segundo uma lei secreta que permaneceria invariante ao longo do processo metamórfico, dado ser ela uma lei que explica tal processo.

ORG 3 - Acredito tratar-se de uma diferença gramatical. A gramática evolutiva ou evolucionista crê que a luz, o bem, o bom, o justo, a igualdade, a libertação, a recompensa, o paraíso certamente virá, mas apenas como resultante de uma luta, de um trabalho, de um empenho, de um esforço, de uma organização, de um mérito, de uma conquista etc., ao passo que a gramática morfológico-cerimonial crê que basta por-se a ver, pois tudo já está sempre posto, do modo como está posto.

ORG 1 - Mas, ao fazer tal distinção entre ambos os métodos orientados por gramáticas diferentes, LW não só critica a ambos pelo fato de se basearem em hipóteses, mas aponta também para a possibilidade de agir metodicamente sem se deixar orientar por qualquer desejo de explicação, por qualquer hipótese. É outro, portanto, o desejo do método terapêutico, qual seja, o de não desejar explicar e, portanto, de não se deixar orientar por qualquer hipótese.

ORG 3 - Correto! O desejo do método terapêutico é, então, o de tão somente apresentar, isto é, dar a ver os dados na sua relação uns com os outros, resumi-los numa imagem panorâmica. LW não vê tal desejo em confronto com os dois outros, mas como uma terceira alternativa aos dois.

$\mathbf{J A}^{111}$ - "E assim o coro aponta para uma lei secreta" é um "verso de Goethe que aparece no poema Die Metamorphose der Pflanzen (A Metamorfose das Plantas). Uma folha única daria origem a todos os vegetais, segundo uma lei secreta. Trata-se da ideia da Urpflanze, a planta primordial, uma realidade espiritual, não sensivel, arquetípica, que não pode ser alcançada pelo puro sentido, mas apenas pelo pensamento que, desarmado de pressuposições, faz correlações entre o perceptivel,

111 (ALMEIDA, in LW, 2007, Nota 82, p. 221, grifo nosso). 
seu entorno variável e o desenvolvimento evolutivo do protótipo. Isto é, uma visão é alcançada desde que essas correlações sejam estabelecidas. Vê-se então que esse arquétipo universal pode sofrer um sem-número de transformações, dando origem à extrema variedade de entes vegetais. Mas todas essas metamorfoses decorrem das leis formativas internas presentes na planta primordial. Leis de natureza orgânica e formal, não de natureza mecânica e matematizável. Não são tampouco as influências exteriores que transformam esse arquétipo, mas o que já está presente nele mesmo. As influências externas apenas fazem com que suas forças plasmadoras internas se manifestem de um modo peculiar. São essas forças internas - e somente elas, segundo Goethe - o princípio constitutivo das plantas. Para vê-las é mais apropriado ao cientista um caráter poético e profundo do que um procedimento exato e naturalista. Trata-se de enxergar a "natureza viva" e trocar a alternativa "verdadeiro/falso" pela disjunção "superficial/profundo".

\section{O ver como o olho gramatical morfológico-normativo vê}

$\mathbf{A M}^{112}$ - "É possível acusar semelhanças de família entre o método vitalista morfológico-analógico de Goethe e o método metamórfico-analógico formal que o matemático alemão Christian Félix Klein, em seu projeto de investigação da geometria que ele expôs em seu Programa de Erlangen ${ }^{113}$, em 1872 e, portanto, há aproximadamente 40 anos após a morte de Goethe, num momento em que, no contexto da matemática acadêmica alemã, a noção de estrutura já havia sido incorporada ao discurso matemático com um significado específico bem determinado. Ambos são métodos metamórficos e ambos postulam uma forma original em relação à qual as semelhanças entre ela e as suas metamorfoses ou variações metamórficas podem ser descritas, características estas que já se destacam nas palavras de Klein, no prefácio à versão de 1893 de seu programa: "Meu programa de 1872 [...] teve, inicialmente, uma tiragem limitada, com o que eu poderia me sentir satisfeito, uma vez que não se poderia esperar que os pontos de vista desenvolvidos no Programa recebessem inicialmente muita atenção. Entretanto, agora que o desenvolvimento geral da matemática vem tomando a mesma direção que a destes pontos de vista, e, particularmente, desde quando Lie iniciou a publicação estendida, em 1890, de sua Teoria dos Grupos de Transformação, parece adequado dar uma maior circulação para as exposições de meu Programa". Anteriormente aos trabalhos de Klein, a noção de estrutura já havia se mostrado matematicamente produtiva nas investigações que o matemático francês Evariste Galois - que morreu no mesmo ano que Goethe - havia conduzido no domínio das equações algébricas, na primeira metade do século XIX. Tanto as investigações de Galois no domínio da Álgebra, quanto as de Klein, no domínio da Geometria, foram orientadas por um método metamórfico-analógico estruturalista semelhante ao de Goethe. E podemos ainda dizer que essas duas investigações se mostraram radicalmente produtivas no sentido de

112 (MIGUEL, 2016a, p. 544-546, grifo nosso).

113 Embora seja usual referir-se à conferência ministrada por Felix Klein (1849-1925), por ocasião da abertura do ano acadêmico de 1872 da Universidade de Erlangen, na Alemanha, como Programa de Erlangen (KLEIN, 1984), o título original daquela conferência era "Vergleichende Betrachtungen über neuere geometrische Forschungen", isto é, "Considerações comparativas sobre as Pesquisas Geométricas Modernas". Na breve apresentação de sua tradução para o português da versão mais conhecida dessa conferência, publicada em 1893, o professor Normando Celso Fernandes destaca: "Seria desnecessário realçar aqui a importância do Programa de Erlangen na história do desenvolvimento da ciência do século XX. No dizer de Jean Dieudonné, esse trabalho serve como um verdadeiro "divisor de águas" que coroa a longa e brilhante evolução da Geometria Projetiva, graças ao enfoque fundamental colocado no conceito de grupo" (KLEIN, 1984, p. 1). 
modificarem a própria concepção que, até meados do século XIX, o mundo acadêmico europeu tinha da Álgebra e também da Geometria. Se até então, a Álgebra era vista apenas como uma teoria das equações, isto é, como uma teoria aritmética generalizada, as investigações de Galois permitiram uma ampliação do domínio dos objetos de investigação da Álgebra, incluindo-se nele a noção de estrutura. As investigações que, a partir de então, passaram a ser realizadas, sobretudo na Alemanha, de uma variedade de estruturas algébricas levaram à percepção de que o estudo sistemático de cada tipo de estrutura poderia ser visto, ele próprio, como uma álgebra diferente daquela a que um estudo de outro tipo de estrutura poderia conduzir. Assim, a própria concepção de Álgebra se estende de modo a tornar-se legítimo falar em álgebras no plural. Extensão análoga, agora no domínio da geometria, é proporcionada pelas investigações de Klein. Até então, a geometria euclidiana era a única geometria digna desse nome, dado ser ela vista como a única teoria verdadeira acerca das formas e das relações morfológicas idealizadas entre as formas presentes no espaço físico. Mas a geometria euclidiana era um estudo intramórfico, isto é, um estudo das propriedades essenciais internas das formas de objetos idealizados e de suas partes. A novidade introduzida pelas investigações de Klein foi a de passar de um estudo intramórfico das formas para um estudo metamórfico das formas, submetendo uma forma típica a um conjunto sucessivo de transformações espaciais com o propósito de se verificar que propriedades originais da forma primitiva mantinham-se invariantes após cada tipo de transformação a ela imposta, estudo este que passou a ser posteriormente conhecido como geometria pelas transformações".

ORG 2 - Quero apresentar aqui uma imagem do método metamórfico-estruturalista das formas geométricas de Klein. "Não pensem, vejam!"

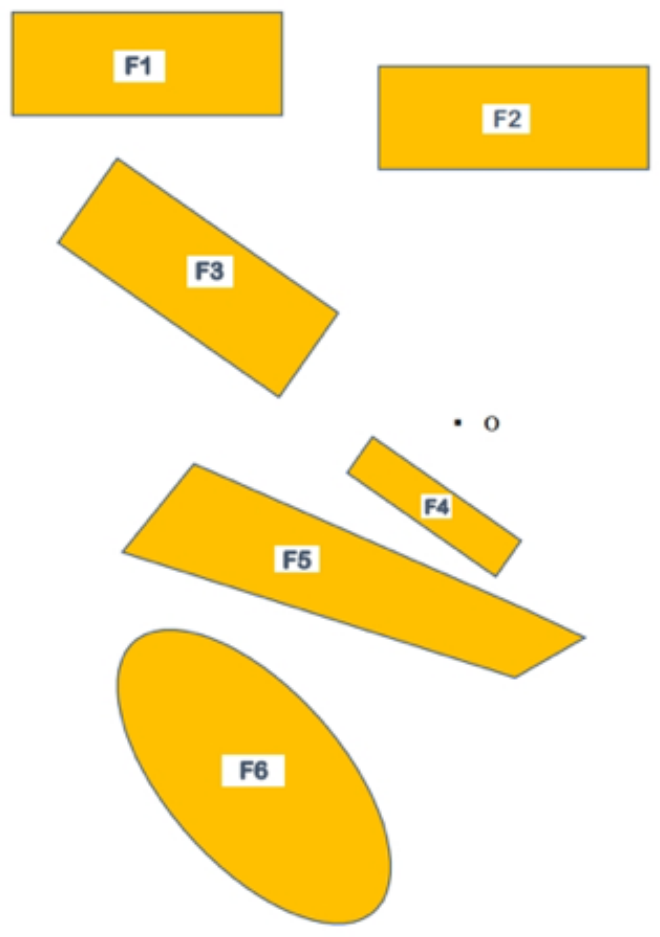


O retângulo F1 constitui a forma geométrica original sobre a qual fizemos incidir uma transformação T1, vista como uma operação ou função que transformou a Figura 1 na Figura 2. A função T1 submeteu a Figura 1 a um movimento de translação, isto é, levou-a apenas a mudar de posição na folha de papel, transformando-a na Figura 2. A função T2 submeteu a Figura 2 a um movimento de rotação central, mudando a sua posição na folha de papel através de um giro sobre si mesma em torno do seu centro fixo, transformando-a na Figura 3. A função T3 submeteu a Figura 3 a um movimento de redução por homotetia - isto é, uma redução em que o comprimento do retângulo diminuiu proporcionalmente em relação à sua largura -, transformando-a na Figura 4. Por sua vez, a função T4 submeteu a Figura 4 a uma transformação projetiva, transformando-a no quadrilátero F5. Uma transformação projetiva, também denominada cônica ou dos pintores é aquela em que os vértices correspondentes da figura original e da figura projetivamente transformada situam-se na mesma linha reta que os liga ao centro $\mathrm{O}$ de projeção. É como se a figura projetada fosse aquela desenhada por um pintor em sua tela, quando ele a olha sob uma determinada perspectiva. No nosso exemplo, o olho do pintor está situado no ponto O. Finalmente, a função T5 submeteu a Figura 5 a uma transformação topológica, transformando-a na elipse F6. Uma transformação topológica que deforma de qualquer modo o contorno da figura sem, entretanto, modificar a sua "identidade poligonal", isto é, se ela é um polígono convexo, uma transformação topológica não pode transformá-lo côncavo e vice-versa. Assim, cada transformação nada mais é senão um conjunto de regras que definem claramente a sua "identidade" ou "gramática", isto é, aquilo que lhe é permitido fazer - e, por extensão, o que não lhe é permitido fazer - com a figura sobre a qual ela opera. Uma vez descrito o modo como o método kleiniano opera, torna-se então possível descrever como cada transformação, mediante a gramática que orienta a sua operação, não apenas modifica a forma da figura sobre a qual ela opera, como também as propriedades da figura sobre a qual ela opera que permanecem invariantes após a sua transformação em uma outra figura. No caso do nosso exemplo: 1) T1 transformou o retângulo F1 no retângulo F2 a ele congruente, deixando invariantes os comprimentos e o paralelismo dos lados correspondentes, as medidas dos ângulos internos correspondentes, a retilinearidade e a convexidade dos contornos ou fronteiras dos retângulos; 2) T2 transformou o retângulo F2 no retângulo F3 a ele congruente, deixando invariantes os comprimentos e o paralelismo dos lados correspondentes, as medidas dos ângulos internos correspondentes, a retilinearidade e a convexidade dos contornos ou fronteiras dos retângulos; T3 transformou o retângulo F3 no retângulo $\mathrm{F} 4$ a ele semelhante, e não mais congruente, deixando invariantes apenas o paralelismo dos lados correspondentes, as medidas dos ângulos internos correspondentes, a retilinearidade e a convexidade dos contornos ou fronteiras dos retângulos; T4 transformou o retângulo F4 no quadrilátero F5 não mais semelhante a ele, deixando invariantes apenas a retilinearidade e a convexidade dos contornos ou fronteiras dos dos dois polígonos; T5 transformou o quadrilátero F5 na elipse F6, deixando invariantes apenas a convexidade dos contornos ou fronteiras das duas figuras. A conclusão disso tudo é que, com base neste novo modo panorâmico de ver as diferentes geometrias, o próprio significado da palavra forma se transforma, de modo que duas figuras se dizem isomórficas - isto é, são ditas possuírem a mesma forma - quando elas mantém entre si semelhanças de família, isto é, quando pertencem a uma mesma família, sendo cada família caracterizada pelo conjunto infinito de figuras que mantém as mesmas propriedades invariantes após serem submetidas 
a um mesmo tipo de transformação. Por exemplo, todos os retângulos homotéticos entre si, isto é, semelhantes entre si, são isomórficos ou homoteticamente equivalentes; todos os quadriláteros que podem ser obtidos mediante a mesma transformação projetiva (e eles são infinitos) são isomórficos entre si, isto é, projetivamente equivalentes; todos os círculos e elipses são topologicamente isomórficos ou equivalentes ou, mais amplamente, todas as figuras convexas, independentemente das formas de seus contornos são topologicamente isomórficas ou equivalente etc.

ORG 2 - A partir da primeira, quero propor uma segunda imagem do método metamórficoestruturalista das formas geométricas de Klein que o mostre em seu aspecto panorâmico. Em meados do século 19, o olhar altaneiro que Félix Klein lançou sobre as diferentes geometrias que haviam sido produzidas ao longo da história - a geometria euclidiana, com o seu olhar arquitetônico plano e planificador da physis e indiferente ao mundo praxiológico; a geometria analítica cartesiana com o seu olhar algébrico-sintético-cartográfico conquistador-explorador de terras e mares distantes nunca dantes navegados; a geometria projetiva com o seu olhar qualitativo-descritivo arquitetônico-representacional de cenas, paisagens, terrenos e construções civis e militares; a geometria topológica com o seu micro e macro-olhar geotopográfico demarcador de fronteiras, vizinhanças e limites territoriais de todos os espaços possíveis; as geometrias não-euclidianas que alargando os horizontes do infinito potencial euclidiano, lançou o seu olhar à exploração de todos os novos horizontes de espaços infinitos atuais, de espaços transfinitos - deu-nos a ver, em perspectiva panorâmica luminosa e dourada, a real fisiognomia genérica e abstrata da razão geométricometamórfica que havia orientado, desde o Renascimento, o projeto colonizador bélicoexpansionista europeu que conquistou o poder político global através de todas as revoluções liberais burguesas que se sucederam a partir da francesa, ocorrida em 1789, bem como das revoluções republicanas de independência das colônias, a partir da revolução americana de 1776.

$\mathbf{A M}^{114}$ - "Tal como o de Galois em relação à Álgebra, o método metamórfico de Klein, ao romper com o essencialismo e o dogmatismo conceituais, permitiu apresentar todas as geometrias historicamente constituidas até o século XIX sob uma visão panorâmica, o que tornou também permissível, no domínio da própria matemática acadêmica, falar-se em geometrias no plural. Se olharmos para cada uma dessas transformações como um tipo - e, no caso de Klein cada uma dessas transformações era vista como uma estrutura típica - e para a forma referencial de partida como uma forma primordial, é possível estabelecer uma analogia direta entre o método analógico-morfológico de Goethe e o de Klein, ainda que aplicados a domínios diferentes de objetos, o das plantas, no caso de Goethe e o das próprias formas geométricas abstratas, no caso de Klein. Só que, o método de Klein era, de fato, um método analógico-morfológico estruturalista - porque as metamorfoses sucessivas pelas quais passava a forma geométrica original eram de fato prévias e normativamente controladas pela noção de estrutura -, ao passo que, no método de Goethe, o estudo do processo metamórfico de uma planta era normativamente controlado por uma força vital natural sobre a qual o controle humano não poderia exercer qualquer papel. Nesse domínio,

114 (MIGUEL, 2016a, p. 547, grifo nosso). 
a percepção humana deveria submeter-se ao controle da natureza e acompanhar os seus ciclos e ritmos, manifestos de modo diferente para cada fenômeno natural sob investigação. Isso poderia ser visto como uma espécie de vitalismo. Isso porque, no caso do método de Goethe, as características de cada etapa do processo metamórfico de uma planta, por exemplo, estão abertas à nossa percepção e observação, mas tais características só podem ser descritas por serem elas normativamente regidas por um impulso natural vital acima de nosso controle, ou apenas parcialmente controlável. Já no caso do método morfológico-estrutural de Klein, ou dos matemáticos em geral, as características dessas transformações podem ser completamente controladas e descritas, uma vez que as estruturas que as regem nada mais são do que um conjunto de regras previamente definidas às quais o objeto matemático formal considerado deve obedecer a fim de se verificar que propriedades desse objeto formal permanecem invariantes a cada metamorfose que se opera sobre ele de acordo com uma gramática definida".

ORG 1 - De certo modo, um método tipicamente estruturalista já estava em largo uso no contexto da matemática alemã, em meados do século 19, antes mesmo do advento do estruturalismo como um movimento organizado na história, a partir da análise estrutural da linguagem levada a cabo pelo pensador russo Roman Jakobson, o qual, aliás, foi chamado por Haroldo de Campos de o poeta da linguística. Assim, é possível acusar semelhanças e diferenças entre poesia, estruturalismo botânico, estruturalismo matemático, estruturalismo linguístico e terapia filosófica wittgensteiniana.

ORG 2 - Uma diferença, por exemplo, é que, ao contrário do método terapêutico wittgensteiniano, o movimento estruturalista sempre reivindicou um estatuto de cientificidade para suas análises estruturais, quer fossem realizadas na linguística, na antropologia, na matemática, nos estudos literários, na história. Tal movimento também produziu, ao longo do século XX, filosofias estruturalistas da história com suas correspondentes histórias estruturalistas da bistória e, até mesmo, de histórias estruturalistas da matemática. Tais histórias e filosofias estruturalistas da história (da matemática) - quase todas críticas do evolucionismo linear e da filosofia positivista de Comte - foram produzidas ou com base em uma filosofia evolucionista- estruturalista não linear e dialética da história, ou então, com base em uma filosofia organicista-estruturalista cíclica da história, inspiradas, sobretudo, no método morfológico-organicista de Spengler e, por extensão, no método naturalista-organicista de Goethe ${ }^{115}$.

ORG 3 - Mas se é possível ver semelhanças, é também possível ver diferenças entre o método de Goethe e o de LW. Por exemplo, para LW, não pode existir uma gramática fenomenológica - isto é, uma "gramática dos fenômenos naturais", uma "voz da natureza", uma "linguagem da natureza" que pudesse ser diretamente auscultada, captada, interpretada, traduzida, significada independentemente de negociações ou acordos normativos vitais que seres humanos estabelecem entre si e com outros seres naturais. Não acordos exclusivos entre humanos, mas acordos entre formas de vida. Penso ser este um dos aspectos cruciais que distinguem um suposto "vitalismo" morfológico-analógico-

115 Segmento composto com base em (MIGUEL, 2015, p. 544-548). 
linguageiro, multivital e não essencialista de LW do vitalismo morfológico-analógico binário (dado que assentado na oposição entre natureza e cultura), naturalista (dado que a natureza é pré-significativa e os seres humanos devem com ela se relacionar de forma subordinada) e estruturalista de Goethe.

ORG 1 - Correto! Parece ser este o aspecto do método analógico-morfológico de Goethe que ecoa na terapia wittgensteiniana. Método este que se deixa orientar por uma lógica da verossimilhança que procura ver analogias entre as diferentes formas assumidas por uma mesma forma que se metamorfoseia com base nas leis da natureza, e que legitima ou não tais analogias exclusivamente com base naquilo que nos mostra a vida orgânica da natureza e a natureza orgânica da vida. Uma investigação terapêutica é COMO SE fosse uma investigação que se deixaria conduzir exclusivamente pelos COMO SE das analogias, que se deixa conduzir por uma lógica orgânica, sensível, mimético-analógica, e não por lógicas dedutivas, indutivas ou mesmo abdutivas ou indiciárias.

ORG 3 - Bate-me, porém, uma certa dúvida diante desta sua certez̧a em relação à fisiognomia não indiciária de uma historiografia terapêutica...

$\mathbf{J G}^{116}$ - Não quero. Dize a eles!

Em alto e bom som: não quero!

É a vontade deles contra a minha!

Um contra um, Parece-me claro!

$\mathbf{J G}^{117}$ - Quando tudo - desejo, alegria e dor -

Em tempestuoso gozo desintegrar-se,

Então recriar-se-á um sono de felicidade,

E aí tu renascerás, novamente jovem,

Para, novamente, temer, esperar e desejar!

\footnotetext{
116 Versos iniciais do "Prometheus" de Goethe. "Prometheus é um fragmento dramático escrito pelo jovem J.W. von Goethe entre 1771 e 1775 e pertencente ao movimento literário alemão chamado Sturm und Drang. Prometeu, personagem da mitologia grega, emblema da rebelião dos homens contra os deuses, irá, no texto de Goethe, mostrar seu desejo de independência e revolta contra a criação divina. O fragmento pode ser dividido em quatro partes. Na primeira parte, Prometeu deixa claro que a Terra lhe pertence e que Zeus deverá permanecer nos Céus; ele não aceita nenbuma proposta que tenha como meta a divisão de poderes. Isto fica bem nítido quando fala do "meu" e do "teu". Num segundo momento ele mostra, de forma expressiva, quão insignificantes foram as benesses que os deuses deram aos homens. Na terceira parte, faz um retrospecto de seu passado fundamentando as razões de sua negativa à proposta de divisão de poderes que lhe fora transmitida. Finalmente, na quarta e última parte, Prometeu mostra a Zeus sua recriação da humanidade, que irá viver num mundo muito melhor do que aquele que os deuses criaram. Trata-se de um verdadeiro bino de amor à sua criação colocada em oposição àquela que seria obra divina (SOUTO, 2010, p. 204-205, grifo nosso).

117 Versos finais do "Prometheus" de Goethe ditos a Pandora que lhe interrogava: - "E depois da morte"? (SOUTO, 2010, p. 241).
} 
$\mathbf{P R}^{118}$ - O Prometeu acorrentado-amigo-do-homem de Rubens

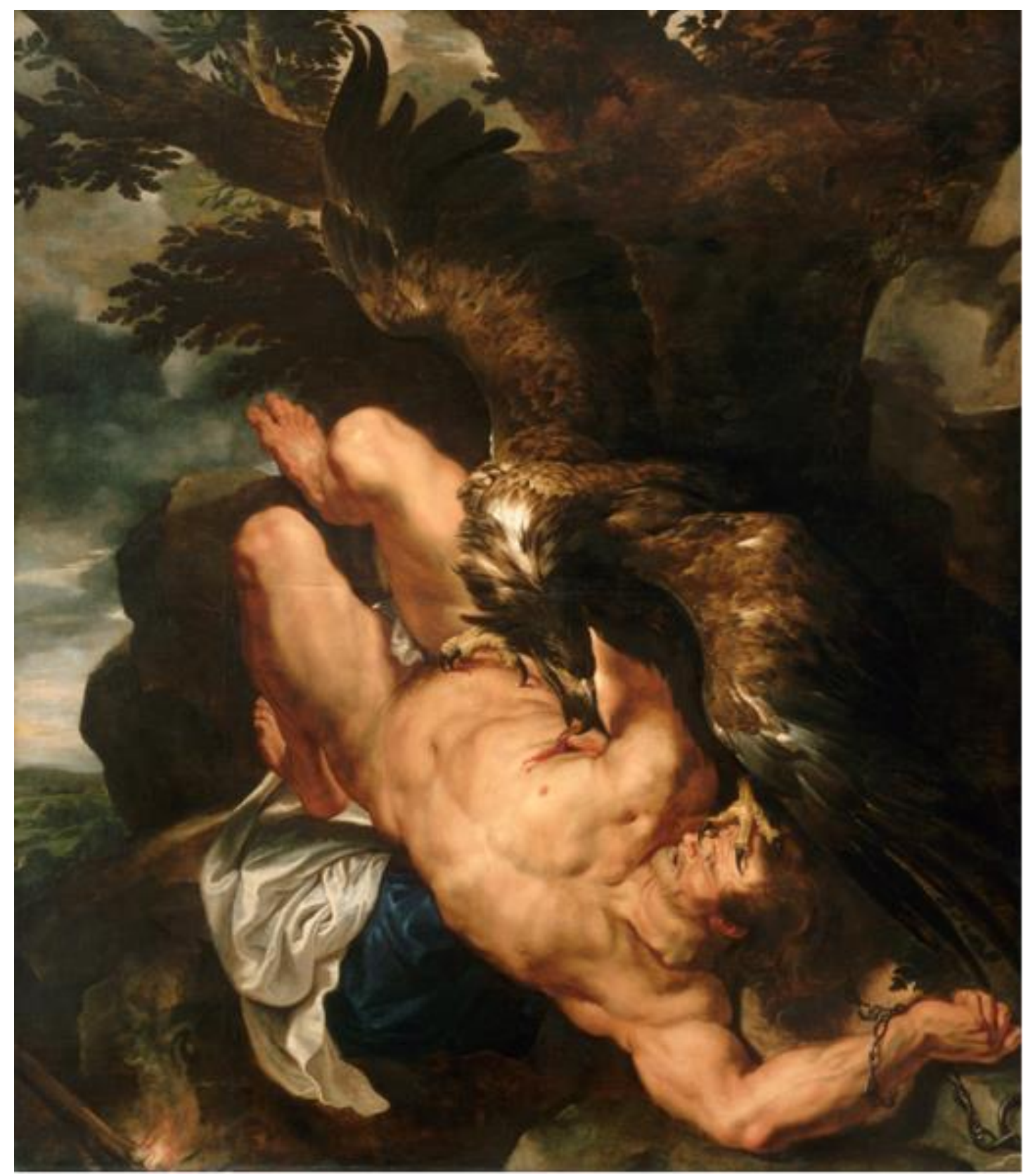

118 Olho sobre tela (1612) de Peter Paul Rubens (1577-1640) - pintor barroco belga de obras temáticas mitológicas, alegóricas e contrarreformistas - intitulado "Prometeu acorrentado" que atualmente integra a coleção do Museu de Arte da Filadélfia, Pensilvânia. A obra foi produzida a partir do efeito performativo gerado pela peça grega Prometeu: o amigo do homem, atribuída a Ésquilo, tendo Rubens tomado como modelo, em seu estúdio, o ator Frans Snyders que havia representado a águia na montagem renascentista europeia da peça. Disponível no site seguinte acessado em 05 de novembro de 2020: <https://en.wikipedia.org/wiki/Prometheus_Bound_(Rubens)>. 
$\mathbf{C D}^{119}$ - O olho gramatical semiótico-indiciário de Conan Doyle visto pela lente gramaticalabdutiva de Sherlock Holmes em Um estudo em vermelho (DOYLE, 2009).

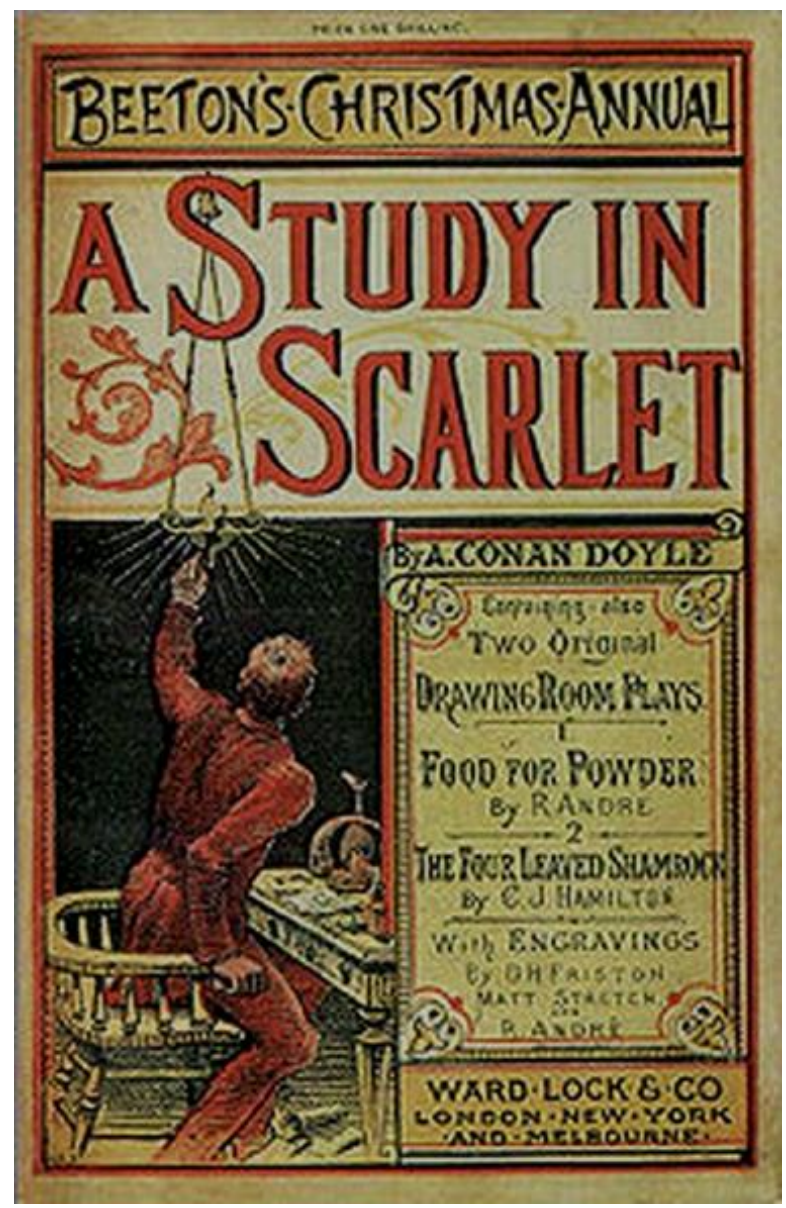

ORGS - O olho gramatical morfológico-naturalista-estruturalista do jovem Goethe, após ter negado, com revolta e rebeldia, qualquer proposta de compartilhar com deuses os poderes humanos na Terra, não teve tempo de renascer para se dar conta de que o seu micro-olhar de deus humanista, qualitativamente preso aos aspectos invariantes internos das metamorfoses da natureza, havia se recusado também subir ao cavalier napoleônico para de lá

\footnotetext{
119 “Um Estudo em Vermelho (A Study in Scarlet no original em inglês) é um romance escrito pelo médico escocês Sir Arthur Conan Doyle (1859-1930) publicado originalmente em 1887. A obra é famosa por ser o primeiro livro de Sherlock Holmes, detetive mundialmente conhecido na literatura policial. É também, nessa obra, que acontece seu encontro com Dr. Watson, narrador e participante das aventuras do detetive através de um amigo comum. Um Estudo em Vermelho propõe um enigma terrível para a polícia, que pede auxílio a Holmes: um homem é encontrado morto, sem ferimentos e cercado de manchas de sangue. Em seu rosto, uma expressão de pavor. O livro é dividido em duas partes: na primeira, é apresentado o caso, algumas deduções do detetive-consultor e a captura inesperada do assassino no final; na segunda parte, é apresentada a vida dos Mórmons, na zona rural dos Estados Unidos da América e os motivos iniciais que levaram o assassino a cometer os crimes. Nos dois últimos capítulos, o Dr. Watson volta a narrar o desfecho do caso e é apresentada a explicação de Sherlock Holmes acerca de como ele conseguiu saber a verdadeira identidade do assassino em apenas três dias através da sua arte de dedução". Disponível no seguinte site acessado em 05 de novembro de 2020: (https://pt.wikipedia.org/wiki/Um_Estudo_em_Vermelho). Não se trata, a rigor, de "arte de dedução". A "nova arte" acionada por Holmes - e que, em meados do século 19, estava sendo investigada pelo filósofo, linguista e matemático Charles Sanders Peirce (1839-1914) como uma terceira forma, dentre as duas outras já estabelecidas, a dedução e a indução, de se estabelecer hipóteses científicas - era o raciocinio inferencial por abdução, visto pelo olho gramatical aristotélico como apagogia: "modalidade de silogismo em que a premissa maior é correta, e a menor, apenas provável, o que compromete a veracidade irrefutável de uma conclusão que, todavia, se mantém logicamente necessária".
} 
observá-las com um macro-olhar telescópico de ave de rapina. Goethe não teve tempo de renascer para ver que, no mesmo século em que o olho gramatical de Mary Shelley passou a olhar, com suspeita, o misterioso impulso vital do deus-natureza da metamorfose das plantas, confrontando-o com a vida artificial quimicamente produzida do seu Frankenstein dotados de olhos vermelhos carregados de vingança contra a humanidade, o olho gramatical abdutivo do médico-detetive Conan Doyle, no seu "A Study in Scarlet", inventava Sherlock Holmes. Assim, o macro-olho historiográfico-panorâmico de águia que contemplava de cima o plano da linha de terra da vida, desce do seu cavalier e passa a investigá-la com o seu micro-olho de caçador-detetive que observa, sonda, fareja, rastreia, mapeia, segue pistas, inspeciona, traça rotas, seleciona, joga dados, calcula probabilidades, infere, controla, descreve e coloniza de outro modo a paisagem ao seu redor.

\section{O ver como o olho gramatical indiciário vê}

ORGS - Uma historiografia terapêutica se assemelha a uma historiografia indiciária? Almeida ${ }^{120}$ critica a tradução de Hacker \& Schulte da expressão alemã übersichtliche Darstellung por "surveyable representation" (representação investigável, pesquisável, vistoriáve) por ela sugerir uma conotação detetivesca do conceito wittgensteiniano de apresentação panorâmica. Estaria Almeida seguindo uma pista adequada ao tentar nublar a atribuição de uma imagem de Sherlock Holmes a um suposto historiador-terapeuta wittgensteiniano? Em outras palavras, poderíamos acusar semelhanças de família entre uma historiografia terapêuticogramatical e uma perspectiva historiográfica indiciária, tal como a sugeriu e praticou o historiador Carlo Ginzburg? No ensaio historiográfico intitulado No rastro de Israël Bertuccio” que integra o livro "O fio e os rastros: o verdadeiro, o falso e o fictício, Ginzburg orienta-se pelo propósito de dar uma resposta a uma crítica que o historiador Eric Hobsbawn remeteu a historiografias ditas culturais e, particularmente, à perspectiva descontínua e indiciária da micro-bistória que havia sido inaugurada pelo próprio Ginzburg. No contexto da argumentação metodológica dessa investigação historiográfica, na qual ele assume inteiramente a identidade de historiador-detetive que se coloca no rastro do personagem supostamente ficcional Israël Bertuccio, a fim de investigar uma possível conexão entre a sua história e a de Bertuccio Isarello - cujo estatuto de personagem histórica real estaria afastado de qualquer suspeita, por haver dele pesquisa acurada nos cartórios venezianos -, Ginzburg foi levado a citar o seguinte aforismo de Lichtenberg: "Se da minha faca troco a lâmina e depois o cabo, continuo tendo a mesma faca?". Tal citação, por sua vez, o remeteu a LW - um apaixonado leitor de Lichtenberg -, bem como a tecer considerações acerca do conceito de semelhanças de familia:

CG $^{121}$ - "Num primeiro momento, LW usou os retratos compósitos de Galton ${ }^{122}$ para ilustrar a possibilidade de isolar um elemento comum, um fio vermelho (uma metáfora

\footnotetext{
120 (ALMEIDA in LW, s/d, Nota 62, p. 321-323).

121 (GINZBURG, 2007, p. 167-169, grifo nosso).

122 De fato, LW, a partir de certo momento, demonstrou interesse pelas fotografias compósitas realizadas pelo matemático e estatístico inglês Francis Galton, cujas investigações estavam centradas em supostas relações entre fisiognomias compósitas de rostos bumanos e caráter e, mais amplamente, entre fisiognomia e ética.
} 
retomada das Afinidades Eletivas de Goethe ${ }^{123}$ ) no interior de um determinado conjunto. Mais tarde, nas reflexões publicadas após sua morte com o título de Investigações Filosóficas, LW retomou o experimento de Galton para propor um ponto de vista completamente diferente. Os contornos fora de foco dos "retratos compósitos", fruto de entrelaçamentos e superposições parciais, sugeriam uma noção diferente, não essencialista, de "semelhança de família". A metáfora do fio vermelho que corre por toda a extensão da corda era substituída por um emaranhamento muito mais complexo. Numa série de ensaios esclarecedores, o antropólogo inglês Rodney Needham reconstruiu os precedentes históricos da ideia proposta por LW, mostrando que o botânico setecentista Adanson já havia elaborado uma classificação análoga. As séries que Needham definiu como "politéticas" podem incluir componentes caracterizados por traços distintivos do tipo aba, bcb, dcd... Num caso assim, o primeiro e o último elemento da série não têm nenhum traço em comum. A longa sombra projetada nos séculos por Bertuccio Isarello é uma sombra fictícia, uma sombra alheia. Sua voz, sufocada pelo patíbulo, não chegou até nós. Mas justamente porque é importante distinguir entre realidade e fição, devemos aprender a reconhecer quando uma se emaranba na outra, transmitindo-lhe algo que poderíamos chamar, com a palavra cara a Stendhal, de energia".

ORG 3 - Embora Ginzburg pareça demonstrar entendimento da diferença entre a possibilidade de constatação de um fio vermelho - isto é, de traços comuns ou invariantes entre os elementos de um conjunto - e a impossibilidade de identificação de um tal invariante, mas apenas semelhanças de família na imagem desfocada de um retrato compósito, parece haver algo de errado com a conclusão da sua investigação historiográfica. Acho que deveríamos discutir melhor aqui em que a noção wittgensteiniana de semelhanças de família se assemelha com o experimento dos retratos compósitos de Galton e como elas também se diferenciam.

ORG 2 - Bem, os experimentos de Galton foram realizados no domínio do que poderíamos aqui denominar estudos fisiognômicos ou bioético-fisiognômicos. Penso ser conveniente também aproximar e diferenciar os experimentos de Galton de outras estudos que, na época, vinham explorando as pontencialidade de método estruturalista:

$\mathbf{A M}^{124}$ - “O método estruturalista - que opera com o propósito de se buscar estruturas invariantes por trás de transformações que dão visibilidade às diferenças - permite que mãos inescrupulosas, carregadas de desejo de poder, suponham a existência de scripts estruturais outros justamente para apagar as diferenças, reduzindo-as a um rosto típico comum: novo poder colonial do Ocidente científico, tanto sobre o Oriente quanto si próprio, desejoso de identificar supostas purezas ou impurezas comuns a fim de criminalizar supostas impurezas comuns de pessoas comuns e salvar uma suposta pureza comum de pessoas supostamente incomuns. Esse desejo esteve na origem da produção de retratos compósitos pelo antropólogo, meteorologista, matemático e estatístico inglês Francis Galton. Primo de Charles Darwin, ele foi também o criador da palavra engenia e o inventor

\footnotetext{
123 (GOETHE, 1971).

${ }^{124}$ A fala de AM foi composta com base na referência (MIGUEL, 2014, p. 865-872, grifo nosso).
} 
da impressão digital ${ }^{125}$. A potencialidade do método analógico-estruturalista já se evidenciava, neste último domínio, através dos estudos realizados por Galton para classificar, ordenar e indexar marcas características dos dedos das mãos, segundo a maior ou menor variação que apresentam em relação às de outros dedos tomados como padrões. Já no domínio dos estudos eugênicos, no capítulo II do seu Essays in Eugenics ${ }^{126}$ Galton, assumindo conceito ideológico de raça que havia sido introduzido pelo projeto colonialista-expansionista-racista europeu a partir do século XVI, definia a engenia como "a ciência que lida com todas as influências que melhoram as qualidades inatas de uma raça; e também com aquelas que as desenvolvem ao máximo. [...] O que se entende por melhoria? O que entender pela sílaba $e \mathcal{H}$, da palavra engenia, que em inglês equivale a bom? Há uma considerável diferença entre o bem nas várias qualidades e na qualidade do caráter como um todo. O caráter depende em grande parte da proporção entre as qualidades cujo equilíbrio pode ser consideravelmente influenciado pela educação" ${ }^{127}$. Temos ciência dos terríveis desdobramentos de práticas eugênicas ao longo do século XX: ideologia da pureza racial, eugenia nazista e holocausto. Mas essa história, segundo Sekula ${ }^{128}$, não começa na Alemanha, mas sim na Inglaterra, no final do século XIX, com uma encomenda feita a Galton pelo historiador e crítico literário Joseph Jacobs de produzir fotografias compósitas do tipo judeu ou do judeu típico, a partir de fotografias de meninos trabalhadores judeus. Em 1878, Galton escreveu um livro chamado Retratos Compósitos ${ }^{129}$ e, junto com Jacobs, escreveu ensaios publicados em números sucessivos do periódico semanal britânico The Photographic News, nos quais apareceram não só retratos compósitos do tipo judeu, como também retratos compósitos do criminoso típico, do estudante típico, do cientista americano típico e de uma familia típica" ${ }^{130 ":}$

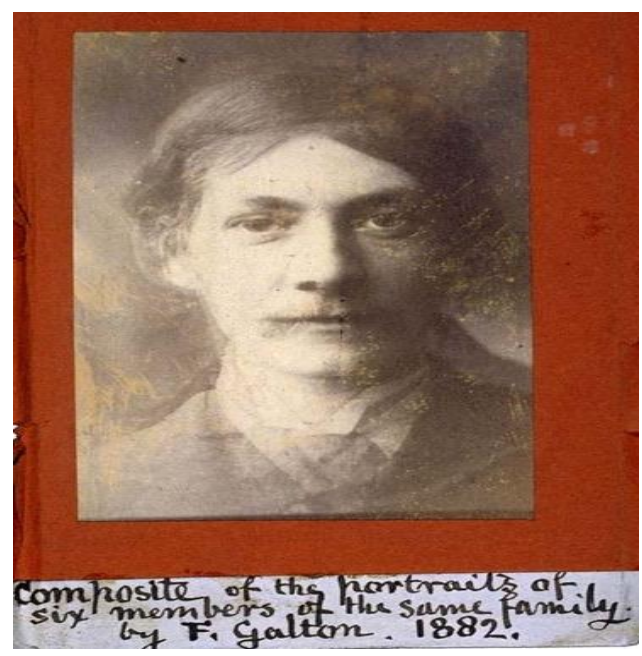

125 (GALTON, 2005).

126 (GALTON, 1909).

127 (GALTON, 1909, p. 40).

128 (SEKULA, 1992, p. 386).

129 (GALTON, 1878).

130 "Composite of the portraits of six members of the same family. By Francis Galton, 1882". Fonte: University College London, GP, 158/2M. Copyright 1999-2004: Cold Spring Harbor Laboratory; American Philosophical Society; Truman State University; Rockefeller Archive Center/Rockefeller University; University of Albany, State University of New York; National Park Service, Statue of Liberty National Monument; University College, London; International Center of Photography; Archiv zur Geschichte der Max-Planck-Gesellschaft, Berlin-Dahlem; and Special Collections, University of Tennessee, Knoxville. Foto disponível no seguinte site acessado em 05 de novembro de 2020: (http://www.eugenicsarchive.org/html/eugenics/static/images/2220.html). 
AM - Já a foto seguinte ${ }^{131}$ é uma composição fotográfica criada por meio da sobreposição de quatro fotos diferentes de faces de quatro pessoas diferentes: o filósofo austríaco Ludwig Wittgenstein e suas três irmãs.

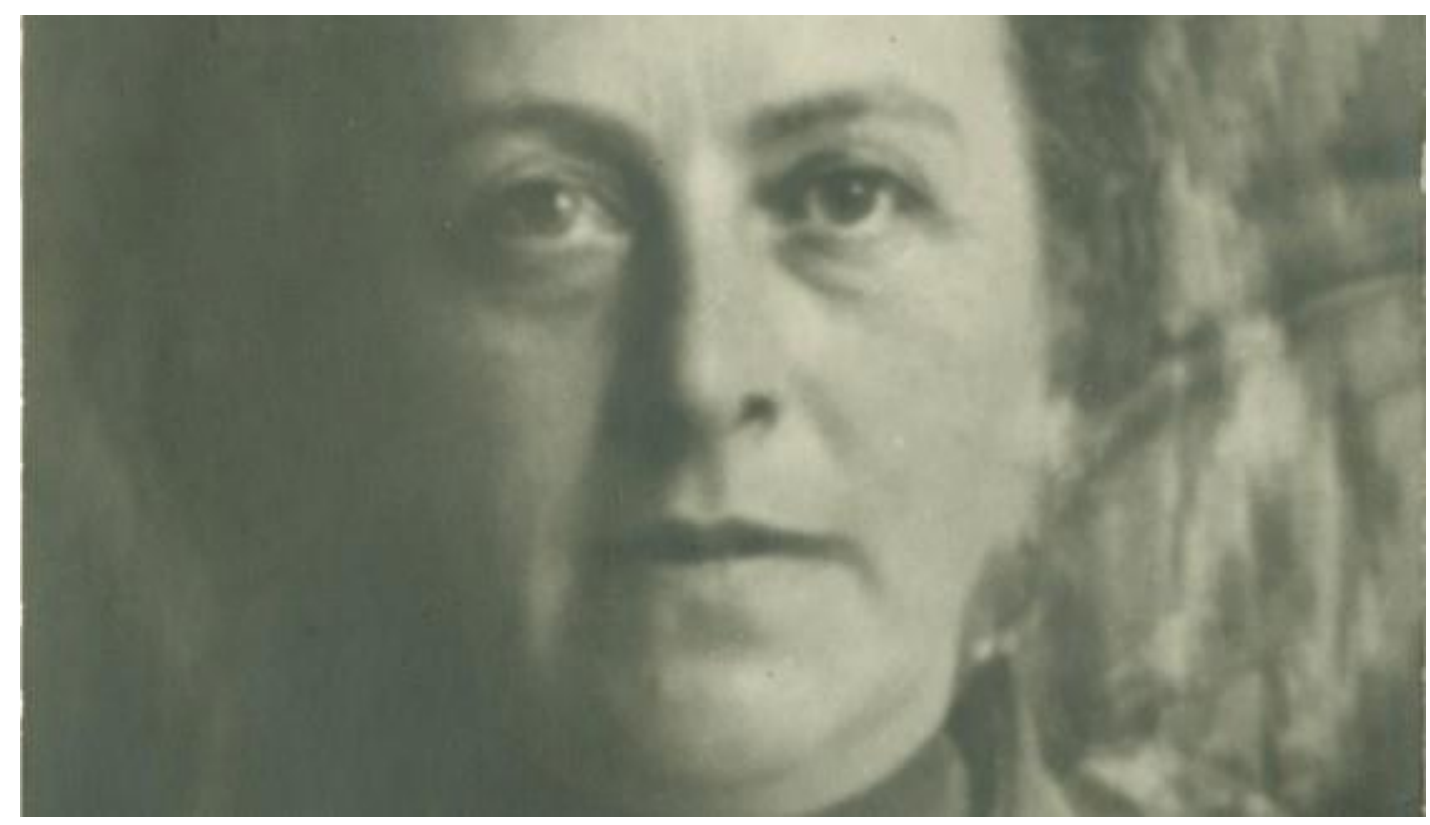

Foi o próprio LW que, em meados da década de 1920, produziu a referida composição fotográfica com a ajuda do fotógrafo Moritz Nahr e, com base em experimentos dessa natureza, cunhou a expressão semelhanças de familia. Mas é preciso fazer uma distinção ideológica de fundo entre os propósitos que orientaram a produção de retratos compósitos por Galton e por Wittgenstein. Baseado no conceito de seleção natural e no temor de degeneração biológica das classes ricas e cultas inglesas de sua época, diante do aumento populacional das classes pobres, o propósito de Galton parece ter sido o de investigar processos de seleção artificial para o aprimoramento biológico e moral da espécie humana. Já o de Wittgenstein parece ter sido o de desconstruir a crença básica da ideologia eugênica indiretamente através da desconstrução de concepções essencialistas dos processos de significação e, mais amplamente, de toda a tradição metafísica da filosofia ocidental e, por extensão, do próprio projeto colonialista expansionista-racista europeu que culminou com o advento do nazismo na Alemanha. Não sendo o rosto compósito o representante de um suposto rosto real ou fictício, e não se podendo identificar nele alguma característica comum a todas as pessoas fotografadas que participam da sua composição, a conclusão a que chegou Wittgenstein foi que ele só poderia ser visto como a resultante imprecisa e desfocada de um rosto em que todos os tipos de possibilidades poderiam ser revelados, mas nunca um traço comum a todos os tipos. Aliás, é exatamente esta a conclusão nãoessencialista, não-estruturalista, anti-racista e decolonialista - que desconstrói toda pretensão racista e eugenista orientadoras dos estudos feitos por Galton dos retratos compósitos - que é mobilizada pelo conceito wittgensteiniano de semelhanças de família ${ }^{132}$.

\footnotetext{
131 Foto extraída de (NEDO, 2011, p. 32), disponível no seguinte site acessado em 05 de novembro de 2020: (http://www.editor.net/BWS/docs/ClareHallCatalogueNew.pdf).

132 A fala de AM foi composta com base na referência (MIGUEL, 2014, p. 865-872, grifo nosso).
} 
AVN 133 - "A expressão semelhanças de família ("Familienänhlichkeiten") foi usada pela primeira vez por Nietzsche, em Para além do bem e do mal ou prelúdio de uma filosofia do futuro $^{134}$, mas foi LW que a usou repetidamente, em seus ataques ao dogmatismo e ao essencialismo. Semelhanças de família são aquelas que reconhecemos entre vários elementos, mas que não dependem de um ou mais atributos ou propriedades invariáveis e comuns que perpassem todos esses elementos. Está-se diante de um caso de semelhanças de família quando aquilo que une os elementos que colocamos sob uma determinada classe não é necessariamente algum atributo comum a todos os elementos da classe. O que os une - a ponto de que nos autorizamos a colocá-los sob um mesmo guarda-chuva, isto é, dentro de uma mesma classe - é uma rede complexa de semelhanças que se entrecruzam ao acaso, sem obedecer a um padrão uniforme. Se observamos algum padrão uniforme na classe é porque, no processo de incluir e classificar os elementos, fomos selecionando atributos que nos interessavam selecionar e, assim, fomos construindo um padrão, só verificável a posteriori. Mesmo assim, veremos que os atributos mudam, se os comparamos de dois em dois elementos incluídos. A metáfora da corda ajuda a compreender melhor. Nas palavras de Glock ${ }^{135}$, aquilo que sustenta uma classe ou um conceito "conferindo-lhe sua unidade, não é um 'fio único' que percorre todos os casos, mas, por assim dizer, uma sobreposição de diferentes fibras, como em uma corda". A analogia à família biológica é assim explicada pelo próprio $\mathrm{LW}^{136}$ : “[...] não posso caracterizar melhor essas semelhanças do que com a expressão 'semelhanças de família'; pois assim se envolvem e se cruzam as diferentes semelhanças que existem entre os membros de uma família: estatura, traços fisionômicos, cor dos olhos, o andar, o temperamento etc." Como explicou Condé ${ }^{137}$, as semelhanças de família são concebidas a partir da diferença, ou seja, “[...] ao estabelecer essa analogia entre diversas características no interior de um jogo de linguagem ou entre vários jogos, o autor [LW] [...] não está propriamente buscando a identidade, a igualdade de um jogo para outro, mas a diferença que, apesar de existir, ainda permite compreender aquela atividade como um jogo de linguagem no interior do qual os usos das palavras estabelecem as significações". Em outros termos, ainda que uma semelhança de família possibilite analogias, ela também permite perceber as diferenças. E é dentro desse jogo de semelhanças e diferenças que nos situamos, estabelecendo nossa racionalidade”.

\footnotetext{
133 (VEIGA-NETO \& LOPES, 2007, p. 19-35, grifo nosso).

134 Veiga-Neto se refere aqui ao parágrafo 20 da referência (NIETZSCHE, 2001): "Dir-se-ia que os diferentes conceitos filosóficos não são nada arbitrários, que não se desenvolvem separadamente, mas que mantém certas semelhanças de família. Precisamente por isso, ao fazer sua aparição na história do pensamento, não deixam de pertencer a um mesmo sistema, exatamente o mesmo que os diversos representantes da fauna do continente [...] Efetivamente, quando há semelhança linguística é inevitável que em virtude de uma filosofia gramatical, exercendo no inconsciente as mesmas funções gramaticais em domínio e direção, tudo se encontra preparado para um desenvolvimento análogo aos sistemas filosóficos, enquanto que o caminho parece fechado para quaisquer outras possibilidades de interpretação do universo. [...] O fascínio que exercem certas funcões gramaticais é, no fundo, o exercido por determinadas valoraçöes fisiológicas e certas particularidades raciais. Isto para refutar as afirmações superficiais de Locke a respeito da origem das ideias". De acordo com Miguel, "nesse parágrafo, Nietzsche utiliza a noção de semelhancas de família para detectar semelhanças entre diferentes conceitos filosóficos, o que o leva a inclui-los em um mesmo sistema na história do pensamento. Porém, tal uso do conceito opera também num contexto de crítica à atividade filosófica que não se interrogaria, segundo o filósofo, acerca da participação de tal conceito na emergência dos próprios sistemas filosóficos. Entretanto, o próprio Nietzsche levanta uma hipótese acerca dessa participação, qual seja, a de que uma valorização de certos conceitos filosóficos seria uma decorrência de uma valorização semelhante de certas funções gramaticais, e a valorização destas últimas, por sua vez, uma decorrência de valorações fisiológicas e de particularidades raciais” (MIGUEL, 2016a, p. 150, grifo nosso).

135 (GLOCK, 1998, p. 325).

136 (LW, IF-67).

137 (CONDÉ, 2004, p. 56).
} 
$\mathbf{A M}^{138}$ - "Não foi apenas Nietzsche que fez uso do conceito de semelhanças de família. Ao longo do século XIX, vários filólogos, no contexto de atividade da Linguística Histórica Comparada, também dele fizeram um uso metodológico a fim de se estabelecer o que denominavam famílias de línguas que eram constituídas com base no critério de identificação, entre elas, de uma língua ancestral comum, denominada protolingua. Também no século XIX, é possível acusar usos dessa noção nos escritos do psicólogo russo Lev Vygotsky (1896-1934) - fundador da psicologia histórico-cultural do desenvolvimento -, bem como nos escritos do professor polonês Vladyslaw Tartarkiewicz (1886-1980), historiador da filosofia e das artes. A taxionomia do século XV III também fez largo uso do conceito, o que seria de se esperar, dado o propósito que orientou a emergência da atividade taxionômica na história, qual seja, o de classificar os organismos biológicos em grupos com base no critério de tais organismos compartilharem certas características comuns. Além disso, podemos também ver semelhanças de família em todos esses usos metodológicos do próprio conceito de semelhanças de familia em diferentes campos e contextos de investigação científica, uma vez que todos esses usos parecem ter constituído seus critérios taxionômicos comparativos especificos com base na analogia entre, por um lado, árvores filogenéticas on genealogicas que definem diferentes familias entre seres humanos e, por outro lado, processos históricos de desenvolvimento de línguas, civilizacõoes, conceitos, ramos do conbecimento, escolas artísticas etc."

ORG $1^{139}$ - Não sei se vocês se deram conta de que Ginzburg, mesmo estando ciente do caráter não essencialista do conceito de semelhanças de família, aciona-o de uma maneira essencialista. Em seu propósito, não propriamente de negar a participação e a relevância da instância ficcional na constituição de uma narrativa historiográfica, mas de constitui-la como um falso brilhante entre a verdade do trigo e a falsidade do joio, ele parece não se dar conta de que, embora seja metodologicamente legítimo usar wittgensteinianamente este conceito para estabelecer e descrever semelhanças ou diferenças entre aspectos de dois ou mais jogos de linguagem, é ilegítimo acioná-lo para tirar conclusões definitivas do tipo sim ou não, verdadeiro ou falso, existe ou não existe, real ou fictício.

ORG 2 - O que você está querendo então dizer é que Ginzburg não se dá conta de que o conceito não essencialista de semelhanças de família não nos autoriza a inferir conclusivamente - isto é, com probabilidade 1 - a partir de nossa certeza sobre a existência do mundo, dos acontecimentos e de nosso próprio corpo, a suposta natureza indubitável de nossas interpretações e modos de significar o mundo e os fenômenos?

ORG 1 - Não é bem isso. Isso é exatamente o que ele pensa poder fazer, isto é, transformar todas as nossas crenças em hipóteses científicas. Pois, lidar probabilisticamente com uma crença, vendo-a como uma inferência provável situada entre zero e 1, é ainda lidar com ela como se fosse um fato, uma bipótese científica que pode ser empiricamente investigável. Penso que, dado o caráter anti-cientificista da perspectiva wittgensteiniana, embora possamos duvidar e modificar nossas crenças, muitas delas não estão abertas à verificação científica,

138 (MIGUEL, 2016a, p. 150-151, grifo nosso).

$139 \mathrm{O}$ diálogo entre vozes que se segue é parcialmente inspirado no diálogo entre vozes que se realiza na referência (MIGUEL, 2016a, p. 156-157). Aqui, entretanto, esse diálogo aparece modificado, acrescido de outras falas, excluído de algunas falas e retificado em muitos aspectos, além de estar cumprindo um propósito diferente do da referência. 
não deveriam ser transformadas em hipóteses factuais ou científicas e, portanto, não deveriam ser vistas nem como verdadeiras e nem como falsas. Por exemplo, o nosso próprio desejo de duvidar da existência do mundo e do nosso próprio corpo não deveria ser transformado numa hipótese científica, não deveria ser cientificamente explicado, ainda que possamos levantar tal dúvida, como muitos filósofos de fato o fizeram. Acreditar, desejar, intencionar etc. não são vistos por Wittgenstein como fenômenos internos, mentais ou psicológicos, mas como expressões corporais que só podem ser significadas num jogo de linguagem, com base na gramática que orienta as ações dos participantes do jogo, isto é, com base nos modos como esses sentimentos são manifestamente expressos pelos corpos dos participantes em jogos de linguagem. Uma pessoa pode, por exemplo, expressar gestualmente a sua crença em um deus ajoelhando-se e fazendo o sinal da cruz dentro de uma igreja; pode também expressá-la linguístico-proposicionalmente de diversas maneiras, dizendo, por exemplo: "eu acredito em deus"; "I believe in god”; “eu não sou cristão, mas acredito em um deus"; "sou politeísta", "I believe in gods" etc.

ORG 2 - O que você está querendo dizer, então, é que Ginzburg lida com proposições ficcionais como se elas fossem fake news, isto é, proposições factuais falsas?

ORG 1 - O que quero dizer é que, em seus jogos indiciários de linguagem, Ginzburg usa a palavra ficção como um sinônimo de não-real, de não-factual, o que lhe permite assumir a identidade de um Sherlock Holmes e investigar indiciariamente - e, portanto, empiricamente - o estatuto existencial de um personagem, o estatuto factual de um acontecimento ou o estatuto epistemológico de uma proposição e, no final da investigação - que sempre deve ter um final -, decidir pela veracidade ou falsidade de tais estatutos, isto é, desvendar um mistério, superar uma contradição, desmascarar uma fake news ou, nas palavras do historiador-indiciário, "distinguir entre realidade e ficção, aprendendo a reconhecer quando uma se emaranha na outra”. Para ele, portanto, uma ficção não se mostra, a rigor, como uma terceira alternativa entre o verdadeiro e o falso, como sugere o subtítulo do seu livro, mas sim como uma hipótese previamente falsa - uma fake news, portanto - cuja falsidade, porém, precisa ser indiciariamente investigada, empiricamente/ materialmente/documentalmente mostrada e narrativamente demonstrada.

ORG 2 - Concluo, então, que esta pseudo-terceira alternativa não deveria ser identificada com a terceira categoria wittgensteiniana de proposições não-hipotéticas ou não-factuais a que você se referiu. Foi por isso que eu me referi inicialmente a ela como um "falso brilhante entre o trigo e o joio" pois, na verdade, antes da investigação historiográfica se iniciar, ela já é postulada como joio...

ORG 1 - Sim, eu lhe dou razão! Na verdade, é a própria crença indiciária de Ginzburg, nem verdadeira e nem falsa, de que uma investigação historiográfica deveria ser metodicamente orientada pelo desejo de se separar o joio do trigo que, sob a perspectiva de uma historiografia terapêutico-gramatical, deveria ser incluída na terceira categoria wittgensteiniana de proposições não-hipotéticas, não-factuais, não empiricamente verificáveis. 
ORG 3 - E daí, concluo eu, uma explicação historiográfica indiciária continuaria presa ao paradigma cientificista, dado que uma narrativa historiográfica indiciária, ao postular como "joio" a ficção, tal como um deus ex machina, só pode continuar costurando com sentido o seu enredo com o fio vermelho goetheano do esquema causa-efeito...

ORG 1 - e não arriscar-se, como o faria uma narrativa terapêutico-historiográfica a dar a ver o seu enredo como um retrato compósito ficcional desfocado, isto é, como uma probabilidade indefinida de paisagem construída mediante a sobreposição de paisagens familiarmente semelhantes em aspectos, mas não como uma paisagem fake.

ORG 3 - É o “Não pense, veja!" Não mais narrativa historiográfica causal ou casual, racional ou irracional, lógica ou não-lógica...mas tão somente narrativa que produza efeitos performativos que não buscam intencionalmente por suas causas, que não buscam explicações para si mesmos, por não se verem a si mesmos como hipotéticos, factuais... efeitos que apenas afetam e desejam afetar, sem se interrogarem pelo por que afetam, mas tão somente por aquilo que afetam, pelo como afetam o que afetam e pelos efeitos dos afetos sobre aquilo que afetam.

ORG 2 - Ou seja, não mais uma narrativa...mas tão somente uma apresentação panorâmica completa, não-hipotética e prima facie, isto é, uma composição desfocada de um número ilimitado mas não exaustivo de descrições descontínuas, sobrepostas e gramaticalmente orientadas de imagens claras, distintas, instantâneas e sincrônicas do problema que se leva ao divã terapêutico.

LW 140 - "Suponhamos que eu tivesse uma memória tão boa que pudesse lembrar-me de todas as minhas impressões sensoriais. Neste caso, nada impede, prima facie, que eu as descreva. Teríamos nisso uma biografia. E por que eu não seria capaz de deixar tudo que é hipotético fora dessa descrição? [...] O tempo dos fenômenos "visuais" isolados é o tempo das nossas expressões comuns da física? Imagino que as mudanças no meu espaço visual são descontínuas e estão em sincronia com as batidas de um metrônomo. Posso, então, descrevê-las e comparar com a descrição com o que efetivamente acontece. Um engano de minha recordação? Não. Um engano que ex hypothesi, não pode ser descoberto não é um engano. $\mathrm{E}$, aqui, o tempo de minha recordação é precisamente o tempo que descrevo".

ORG 2 - Do que dissemos, deveria parecer pelo menos surpreendente para um investigador empírico-indiciário como Ginzburg que ao se colocar bipoteticamente no rastro de um "fictício" personagem histórico, no final do percurso, mesmo não tendo encontrado o cadáver ou a caveira do morto procurado, ele pudesse concluir pelo seu "estatuto ficcional" que, no caso de Ginzburg, é o mesmo que "estatuto não-existencial". O que poderia ser dito de um método historiográfico indiciário que persegue confiantemente a fumaça e não encontra o fogo? Ou que persegue confiantemente os rastros deixados pelo sangue e o que encontra é uma "faca lichtenberguiana" da qual já se havia trocado o cabo e depois a lâmina? O que poderia ser dito de um método historiográfico que constitui

140 (LW, 2005a, seção VII, OF-67 e OF-75, p. 81 e p. 86, grifo nosso). 
a fumaça como um signo indiciário para o fogo e que, portanto, já à partida, pressupõe hipoteticamente, entre a fumaça e o fogo, uma relação de causa e efeito, ou então, uma relação abdutiva de inferência probabilística, e não uma relação analógica de semelhanças de família?

ORG 1 - Penso que, desse método historiográfico, poderíamos dizer qualquer coisa, menos que ele se assemelha a um método historiográfico terapêutico-gramatical. A conclusão a que chego é que o historiador-detetive Ginzburg acaba fazendo um uso bipotético indevido do conceito wittgensteiniano de semelhanças de família para concluir pela ficcionalidade de um personagem histórico que ele pressupõe antes da investigação começar. Cabe a ele, portanto, e a seu método indiciário o mesmo tipo de crítica que LW fez a Frazer:

LW $\mathbf{W}^{141}$ - "Eu creio que o empreendimento de uma explicação já é falho, porque só se tem que organizar corretamente o que se sabe, e nada acrescentar, e vem por si mesma a satisfação a que se aspira pela explicação. E a explicação não é aqui de nenhum modo o que satisfaz. Quando Frazer começa a nos relatar a história do rei do bosque de Nemi, ele o faz num tom que mostra que ele sente, e nos quer fazer sentir, que aqui ocorre algo estranho e temível. Mas a pergunta "por que isso ocorre?" só pode ser respondida na verdade por: por que isso é temível. Isto é, o mesmo que se nos apresenta nesse acontecimento como temível, grandioso, horripilante, trágico etc., não menos que trivial e insignificante, isso gerou esse acontecimento. Aqui só se pode descrever e dizer: assim é a vida humana. A explicação é, comparada com a impressão que a descrição nos causa, demasiado insegura. Toda explicação já é uma hipótese”.

\section{O ver como o olho morfológico cíclico de Spengler vê}

ORGS - Uma historiografia terapêutica se assemelha a uma historiografia morfológica a la Spengler?

JA $^{142}$ - "A maneira imanente ao orgânico de ver a biologia, a morfologia, repercutiu fortemente na visão de história como fisiognomia, a morfologia própria da bistória que trata a cultura como organismo, defendida por Oswald Spengler, o grande inspirador de Wittgenstein para o conceito de "apresentação panorâmica".

ORGS - Mas, se a imagem morfológica spengleriana da história constitui a humanidade não como uma categoria genérica e abstrata, mas como culturas vistas como comunidades culturais que se transformam, não mais segundo uma hipótese de evolução temporal linearmaterial, mas segundo uma hipótese de evolução temporal cíclico-orgânica, então, de acordo com estas imagens da humanidade, da temporalidade e da metamorfose culturalespiritual, não pode haver, a rigor, oposição entre cultura e civilização, uma vez que a civilização é vista como a etapa decadente da metamorfose de uma cultura. É como a Paris, capital do século XIX de Benjamin: mônada simbólico-representativa da etapa última e decadente

141 (LW, 2007, p. 194, grifo nosso).

142 (ALMEIDA, in LW, 2007, Nota 82, p. 221, grifo nosso). 
da cultura europeia, ela é, portanto, a cidade-civilização que anuncia o fim, a extinção dessa própria cultura.

$\mathbf{J A}^{143}$ - A forma de pensar cósmico-orgânica proposta por Spengler em O Declínio do Ocidente, a "fisiognomia", inspirada na morfologia vegetal de Goethe, e que estuda as culturas como organismos em ascensão ou decadência, foi a base de LW, tanto para o conceito de "apresentação panorâmica" quanto para a sua oposição entre cultura e civilização (esta última, a forma decadente que assumiu a nossa cultura). A fisiognomia é uma morfologia descritiva e criativa, ao contrário da sistemática, que é uma morfologia mecânica feita para descobrir leis e relações causais. Esta experiência é cientifica, a outra é vital; na primeira há um distanciamento, na outra, envolvimento; a primeira preocupa-se apenas com a precisão e a quantificaşão, enquanto que a outra é decididamente metafísica e artística. "Descritiva e criativa, a fisiognomia é a arte do retrato transferida para o dominio espiritual'.

ORG 1 - A oposição que fazia Spengler entre morfologia (fisiognomia) sistemática ou científica e morfologia (fisiognomia) descritiva, artística on criativa, reproduz a oposição análoga já anteriormente feita por Goethe em $A$ metamorfose das plantas. Mas, ao colocar em oposição estes dois tipos de fisiognomia, Spengler acaba vendo também como morfológico o olho gramatical evolutivo-linear. Embora ele os veja como dois paradigmas distintos de investigação - um explicativo, científico, quantitativo e o outro descritivo, artístico, criativo, qualitativo -, ele vê a ambos como morfológicos, isto é, como fisiognômicos. Isto ele mesmo nos dá a ver já no título de sua obra - A decadência do Ocidente: esboço de uma morfologia da história universal 144 - que traz as marcas de sua filiação a uma história evolucionista, mas não linear, que é revelada pela palavra decadência, bem como sua filiação ao método organicista de Goethe, o que é revelado pela palavra morfologia ${ }^{145}$. Já o estrutural ou mesmo estruturalista dessa obra, penso eu, é expresso pelo próprio Spengler, na sua Introdução:

SO ${ }^{146}$ - "Existe uma lógica na História? Haverá, além dos feitos avulsos, que são casuais e imprevisíveis, uma estrutura, por assim dizer, metafísica, da Humanidade histórica, e que permaneça independente das conhecidas e manifestas formações político-espirituais, que se veem na superfície? Uma estrutura que, pelo contrário, origine essa realidade secundária? [...] Já que a história humana é a totalidade de enormes ciclos vitais, que a linguagem usual costuma apresentar e personificar, espontaneamente, como indivíduos de ordem superior, ativos e pensantes, chamando-os de "a Antiguidade", "a Cultura Chinesa", "a Civilização Moderna”, será possível descobrir na própria vida os degraus que teremos que escalar, numa sequência que não admite exceção? Os conceitos fundamentais de tudo quanto é orgânico - conceitos tais como nascimento, morte, juventude, velhice, duração da vida não terão eles também, nesta esfera, um sentido estrito que ninguém ainda logrou perceber? Não se baseia, numa palavra, todo o desenvolvimento histórico em certas plataformas biográficas de caráter geral? [...] Por enquanto, não ocorreu a ninguém transformar tais improvisações num método. Ninguém suspeitou sequer que ali se

\footnotetext{
143 (ALMEIDA, in LW, 2007, Nota 87, p. 222, grifo nosso).

144 (SPENGLER, 2014).

145 (MIGUEL, 2016a, p. 548).

146 (SPENGLER, 2014, p. 1-2 e p. 4-5).
} 
encontrava uma raiz, e na realidade a única raiz, da qual pudesse brotar uma grande solução para o problema da História. As comparações poderiam trazer boa sorte ao pensamento histórico, desde que patenteassem a estrutura orgânica da História. [...] Neste ponto, manifesta-se que, por enquanto, não existe nenhuma arte, teoricamente elucidada, da observação histórica. Pensam alguns realizar uma investigação histórica, ao irem em busca do nexo objetivo de causa e efeito. [...] Ainda não penetrou nas nossas formulações teóricas a convicção de que, além da necessidade de causa e efeito - e que eu gosto de chamar de lógica do espaço -, há na vida ainda a necessidade orgânica do Destino - a lógica do tempo. Esta última constitui um fato de profunda certeza íntima; um fato que dá conteúdo a todo o pensamento mitológico, religioso, artístico; um fato que forma o núcleo e a essência de toda a História, em oposição à Natureza, mas que permanece inacessível aos métodos de conhecimento analisados na Crítica da Razão Pura. A Matemática e o princípio da Causalidade conduzem a uma ordem naturalista dos fenômenos. A Cronologia e a ideia do Destino levam a uma ordem histórica. Ambas essas ordens abrangem, cada qual isoladamente, o mundo inteiro. Somente variam os olhos nos quais e através dos quais se realiza esse mundo".

ORG 2 - Tratar-se-ia ainda de uma historiografia evolucionista?

ORG 1 - A rigor não, embora ela compartilhe com historiografias evolucionistas o seu aspecto determinista, mas não mais o aspecto propriamente evolutivo.

ORG 3 - A não ser que a gente retire da palavra "evolução" a conotação de progresso a que ela geralmente se associa. Aí poderíamos ver a teoria da história de Spengler como uma espécie de evolucionismo às avessas... como um evolucionismo cíclico e não mais linear. Além do mais, eu também a vejo como um evolucionismo estruturalista, uma vez que as histórias de todas as civilizações, de acordo com essa teoria da história, deveriam ser escritas "com base em duas lógicas invariantes: a lógica matemático-causal do espaço e a lógica cronológicocasual do tempo. São elas que, segundo Spengler, orientariam as metamorfoses internas de todas as civilizações e selariam os seus destinos, quais sejam, a decadência e a morte" ${ }^{147}$.

ORG 1 - Historiografia duplamente estruturalista. Isso porque, essas duas lógicas invariantes não só funcionam como camisa de força às narrativas historiográficas de cada civilização em suas transformações espaçotemporais internas, como também constituem uma camisa de força às narrativas historiográficas do conjunto das civilizações em suas interações externas ao longo da história: estruturalismo na bistoriografia das partes e estruturalismo na bistoriografia do todo.

ORG 2 - Não consigo ver uma distinção entre a natureza dessas duas lógicas. Não vejo uma como causal e a outra como casual. Se você, ORG 1, vê a teoria da história de Spengler como duplamente estuturalista, eu também a vejo, como duplamente causal, duplamente determinista, dado que, em seu evolucionismo cíclico, todas as civilizações, vistas como organismos, tendem, inevitavelmente, para a decadência. Spengler não deixa espaço para a

147 (MIGUEL, 2016a, p. 550, grifo nosso). 
atuação do acaso, nem em sua lógica do espaço e nem em sua lógica do tempo, dado que os destinos das civilizações estão previamente selados. Se Freud, na cola do Spengler, detectou um mal-estar inalienavelmente estrutural e estruturante na civilização, eu vejo um mal-estar nesse mal-estar...

ORG 1 - De acordo com a historiadora Naiara Ribeiro, em um um livro intitulado "Nas sombras do amanhã: um diagnóstico da enfermidade espiritual de nosso tempo", o historiador holandês Johan Huizinga, contemporâneo de Spengler - e que também defendeu uma imagem morfológica da história diferente da de Spengler -, também fez este mesmo tipo de crítica.

$\mathbf{N R}^{148}$ - "A pergunta sobre se eram os homens que determinavam a história ou a história que determinava os homens - que antes parecia subordinado a uma interrogação de caráter metodológico - assumia, neste momento, os contornos de um problema ético urgente, especialmente com a publicação, em 1918, de $A$ decadência do Ocidente de O. Spengler. Ao defender a tese de que a civilização ocidental estava completando o seu ciclo de vida e caminhava irreversivelmente para a destruição, este filósofo causou uma intensa polêmica em relação tanto à sua teoria da decadência, com traços eminentemente deterministas, quanto aos métodos que havia utilizado em sua "fillosofia da História universal". Diante de um mundo emerso da Primeira Guerra, cada vez mais complexo e exposto à revalorização substancial de seus valores, Spengler certamente tinha contribuído para arrancar aos homens de seu tempo "uma fé desarrazoada na natureza providencial do progresso", familiarizando- os "com a idéia de um declínio da cultura e civilização contemporâneas. [...] O erro fundamental de Spengler, que fazia de seu sistema uma abordagem inadequada para pensar a história universal, era que ele havia percorrido o caminho que da morfologia levava ao mito, em nome de interesses de ordem político-ideológica. Sua visão de culturas "quase-humanas" - que estavam destinadas a ascender e decair num ritmo inelutável - só poderia conduzir a uma percepção míope da história, na medida em que a subordinava ao compasso de uma cega determinação de caráter biológico. Além do mais, Spengler parecia aprisionar os indivíduos à necessidade irrevogável dos fatos, reduzindo-os ao papel de meros expectadores num "teatro do mundo" radicalmente complexo, no qual operavam forças incontroláveis que barravam a ação e a liberdade individual. Huizinga podia até concordar com alguns dos sintomas de decadência que Spengler havia arrolado em relação à civilização ocidental de então. Concordava, por exemplo, que o homem "moderno" vivia sob o primado da técnica, do materialismo e das massas e que estes seriam os responsáveis pela propagação de uma esterilidade espiritual, de uma desoladora uniformidade e de uma, cada vez mais ampla, identificação entre política, guerra e economia. Mas onde Spengler via triunfar as tendências de um processo funesto que conduziria ao fenecimento da civilização ocidental de então, Huizinga via atuar "o destino incalculável do indivíduo" que podia ou não ocasionar a ruína do mundo através de suas escolhas".

NR 149 - "Mas se na aula inaugural de 1905 a "sensibilidade estética" parecia servir para o historiador criar imagens do passado, Huizinga agora lhe atribuía uma nova função: não se

148 (RIBEIRO, 2010, p. 248-249, grifo nosso).

149 (RIBEIRO, 2010, p. 245). 
tratava mais de construir imagens, mas sim perceber as formas nas quais "o passado se condensa" (ANCHOR 1978, p. 75). Diferente da idéia de "reviver" (Nacherleben) da tradição hermenêutica - que parecia sugerir que no simples fato de "re-viver" o passado, como uma "presença imaginária", estivesse já completo o exercício de compreensão histórica -, Huizinga afirmava que o impulso de "ver", de "experimentar" o passado era apenas o princípio da atividade do historiador e não a sua meta propriamente dita. "Compreender historicamente e narrar historicamente implicam qualquer coisa mais do que o simples experimentar e despertar aquela sugestão histórica" (HUIZINGA 1993, p. 73). Mais do que fazer reviver sentimentos e estados de espírito, a História deveria fazer compreender as conexões. Se o "reviver" era ocasional, a compreensão mediante determinadas formas era constante. Assim, as conexões que o historiador fazia ao reunir certos elementos da "tradição" não existiam nem no passado mesmo, tal e como ele foi vivido. "A História é sempre, no que se refere ao passado, uma maneira de dar-lhe forma e não pode aspirar ser outra coisa. É sempre a captação e interpretação de um sentido que se busca no passado" (HUIZINGA 1992, p. 92).

ORGS - É a esta imagem de história que esta obra que decidimos denominar Uma historiografia terapêutica de acasos pretende remeter seus leitores e leitoras. Imagem esta que pensamos ter sido a que Ludwig Wittgenstein também teria gostado de nos remeter, caso tivesse ele improvavelmente se preocupado um dia, em traduzir em palavras, uma suposta teoria da história, coisa que ele certamente abominaria. Não foi este, porém, o caso de Spengler, com cuja teoria da história, acreditamos nós, a imagem morfológicoarquitetônica wittgensteiniana de uma historiografia terapêutica se assemelharia em certos aspectos. Não foi este também o caso de Goethe, com cujas teorias morfológicas acerca das cores, do método científico e da produção de textos literários performativos, acreditamos nós, a imagem morfológico-arquitetônica wittgensteiniana de uma historiografia terapêutica também em certos aspectos se assemelharia.

ORGS - Tanto Spengler quanto Goethe poderiam ter também contribuído para a constituição quer da imagem wittgensteiniana da linguagem como uma caixa de ferramentas, quer da imagem metonímica wittgensteiniana do pensamento não como uma atividade mental ou psicológico-cognitiva, mas como uma atividade manual, isto é, das mãos, como representativas do corpo todo, agindo sobre os signos de um jogo de linguagem. De fato, foi Spengler que em um livro publicado em 1931, com o título Der Mensch und die Technik - O Homem e a Técnica: contribuição a uma filosofia da vida ${ }^{150}$-, defendeu a tese de que as linguagens exclusivamente tátil-manuais produtoras dos primeiros artefatos tecnológicos rudimentares e, por extensão, de diferentes técnicas primitivas, vistas como processos de transformação de seres naturais em artefatos culturais, teriam cronologicamente antecedido, na história naturalista-vitalista da humanidade, as linguagens sonoro-fonemáticas e, portanto, o advento de todas as linguagens orais articuladas constituintes das línguas nativas de diferentes povos. É praticamente impossível, para um leitor atento da obra de Wittgenstein, não conectar estas imagens spenglerianas da técnica de do pensamento como atividade manual das imagens correspondentes de técnica e

150 (SPENGLER, 1941). 
pensamento que Wittgenstein nos mostra nas duas passagens de abertura da seção VI das Observações sobre os fundamentos da matemática: "As provas ordenam as proposições. Elas lhes dão um contexto. O conceito de um exame formal pressupõe o conceito de uma regra de transformação, e, portanto, de uma técnica. Pois somente mediante uma técnica podemos apreender uma regularidade. A técnica está fora da imagem da prova. Podemos ver exatamente a prova e não compreendê-la como transformação segundo essas regras. Certamente chamamos a adição dos números...., para ver se eles dão 1.000, de exame formal dessa técnica operatória. Mas é claro que somente se a adição for uma técnica praticada. Pois se não, como vamos chamar o processo de alguma forma de exame? A prova formal só é um teste formal dentro de uma técnica de transformação" 151 . Nesta passagem das Observações sobre os fundamentos da matemática, LW usa a palavra técnica como sinônimo de regra de transformação. Mas ele também conecta o conceito de técnica ao conceito de regularidade. De que modo os conecta? Dizendo que nós, humanos, só podemos apreender, perceber ou significar uma sequência de ações/interações corporais como comportando uma regularidade (isto é, só percebemos regularidade numa sequência de ações/interações corporais que corpos/seres realizam sobre outros corpos/seres) quando essa sequência de ações constituir uma técnica, isto é, quando essa sequência de ações que corpos/seres (humanos ou não humanos) realizam sobre outros corpos/seres (humanos ou não humanos) for orientada por uma regra ou conjunto de regras que transforma sucessivamente os corpos/seres em interação em outros corpos/seres. Temos nos habituado a denominar de prática cultural, ou simplesmente prática, qualquer sequência de ações ou interações entre seres em que seres humanos possam identificar uma regularidade, isto é, uma regra ou conjunto de regras de transformação que orientam a realização de tal sequência de (inter)ações. Portanto, para nós, soa legítimo identificar uma prática com aquilo que Wittgenstein chama de técnica. Mas é só num jogo de linguagem e mediante um jogo de linguagem que podemos identificar regularidades numa sequência de ações e significá-las como regularidades, isto é, significá-las como regras de transformação que orientam tal sequência de ações. Pois, não podemos perceber regularidades (pela visão, ouvido, tato, olfato ou paladar), isto é, repetições ou iterações de sensações, independentemente de um jogo de linguagem, isto é, independentemente da possibilidade de podermos estabelecer acordos comunitários vitais - isto $e ́$, entre formas de vida - acerca do que nos leva a considerar ou não como legítimos certos como se, certas semelhanças ou verossimilhanças entre sensações. Como se, semelhanças ou verossimilhanças são normas ou regras que humanos e não humanos estabelecem entre si, de forma negociada, em suas interações, são normas que emergem ou se mostram como necessárias nessas interações. São normas praxiológicas, pois elas nem são arbitrariamente impostas por humanos a não humanos e nem por não humanos a humanos. São normas que constituem as técnicas ou práticas por se constituírem através das técnicas ou das práticas. Práticas ou técnicas dependem de jogos de linguagem para se constituírem como e/ou serem significadas como práticas ou técnicas. E dado serem os jogos de linguagem encenações simbólicas ${ }^{152}$ do corpo

\footnotetext{
151 (LW, OFM-VI- \$1-2, grifo nosso).

$152 \mathrm{O}$ modo como estamos aqui nos propondo a ver os jogos wittgensteinianos de linguagem - isto é, como encenações simbólicas do corpo bumano - pode ser comparado à maneira como, na década de 1930, o artista plástico alemão Hans Bellmer - que, tal como Wittgenstein era também um leitor e admirador de do filósofo, astrônomo e matemático alemão Georg-Christoph Lichtenberg (1744-1799) - estabelecia relações entre o corpo e a linguagem. De fato, segundo Taylor, Bellmer "sustentava o ponto de vista de que todos os tipos de produção simbólica estão, em última instância, enraizadas na experiência corporal, tais como, por exemplo, aquelas nas quais estão envolvidos gestos, reflexos, sons, palavras,
} 
humano em interação com corpos de outros seres naturais, eles não podem ser desligados das (inter)ações corporais situadas dos próprios participantes do jogo. De fato, para ele, "Palavras são também açôes" $"$. E num aforismo que nos remete a rastros de significação do Fausto de Goethe, ele não só esclarece os laços de continuidade e não dissociabilidade entre jogos de linguagem e ações corporais, como também, acusa o primado e a conexão - ainda que enganosamente imperceptível - das ações corporais em relação a outras formas supostamente tidas como abstratas ou incorpóreas de se praticar a linguagem: "A linguagem - gostaria de o dizer - é um aperfeiçoamento, no princípio era a ação" ${ }^{\text {"154 }}$.

MG $\mathbf{M G}^{155}$ - "Se, para Goethe, a obra é espelho da vida, para ele mesmo, inevitavelmente, sua vida acabou sendo o espelho de sua obra. Vida e obra, apesar de se colocarem em pólos opostos, parecem indissoluvelmente ligadas entre si. Como ele mesmo admite no seu Tratado sobre a visão e as cores: "Ser significa de maneira geral a mesma coisa que agir". Vale lembrar que, em alemão, realidade (Wirklichkeit) deriva da palavra wirken (agir). A obra (Werk) implica uma efetividade, se constitui ao agir sobre o mundo. É como se devêssemos percorrer o mesmo caminho de Fausto ao reinterpretar o Evangelho segundo são João: "O início era o Verbo". Não achando justo dar prioridade ao verbo, Fausto conclui que o começo não é nem o verbo, enm o sentido, nem a força, mas a ação. Como nos diz Argan: Não tanto pela justeza da variedade e da alternativa o grande literato é assim fortemente atraído por uma linguagem sem palavras, toda feita de imagens visiveis: a linguagem verbal correspondia à esfera conceitual, enquanto a linguagem de imagens, aparentemente tão inconsistente e efêmera, se ligava diretamente à esfera positiva do agir, isto é, da técnica".

WL ${ }^{156}$ - "A ciência e a indústria, e o seu progresso, podem vir a ser a coisa mais duradoura do mundo moderno. Provavelmente, qualquer especulação sobre um futuro colapso da ciência e da indústria não é, por enquanto, e por um longo período de tempo, mais do que um sonho; talvez a ciência e a indústria, responsáveis por misérias infinitas no decorrer do tempo, venham a unir o mundo - quero dizer, a condensá-lo numa única unidade, em que decerto a paz será a última coisa a habitar. Pois a ciência e a indústria decidem guerras, ou pelo menos assim parece".

ORG 3 - Fico em dúvida se o modo como LW via a história não se assemelharia também com o aspecto cíclico-evolutivo-contínuo e teleologicamente decadente que orientava a filosofia spengleriana da história. Já vimos aqui que LW era um crítico da civilização europeia e norte-americana, chegando mesmo a anunciar a sua desintegração, dado que

\footnotetext{
grafismos e objetos. Para ele, figuras de linguagem tais como a hipérbole e a metáfora não pertencem unicamente à literatura, mas também, ao próprio corpo humano, o mesmo ocorrendo com os processos matemáticos que operariam não apenas no domínio abstrato, mas também na carne. Para sugerir que o corpo participa da vida intelectual e que não é a cabeça sożinha que inventa matemática, invocava o aforismo de Lichtenberg de que a nossa convicção sobre a validade de uma equação algébrica reside no cérebro, mas também, em certa medida, no polegar" (TAYLOR, 2000, p. 101-102); (MIGUEL, 2016c, p. 373).

153 (LW, IF-546).

154 (LW, 2000, p. 53, grifo nosso); (MIGUEL, 2016, p. 371).

155 Fala de Marco Giannotti em sua introdução à tradução que faz, para o português, do livro A doutrina das cores de Goethe (GOETHE, 1993, p. 20-21, grifo nosso).

156 (LW, 2000, p. 95, aforismo de 1947).
} 
acreditava que o século XIX havia se mostrado para a humanidade como o limite da cultura ocidental.

ORG 1 - Mas não foi só ele que viu e sentiu este mal estar na civilização ocidental. É claro que o livro de Spengler deve ter funcionado como um catalisador desse sentimento. Em um livro intitulado "O mito do Estado", o filósofo Ernst Cassirer, contemporâneo de LW, disse que, sobretudo a partir do final da Primeira Guerra Mundial, os livros que haviam sido publicados por Spengler incendiavam a imaginação de muitos pensadores, artistas e intelectuais:

EC $^{157}$ - "Neste momento, muitos, se não a maioria de nós, se deu conta de que havia algo de podre no estado de nossa civilização ocidental altamente valorizada. O livro de Spengler expressa de uma forma nítida e incisiva esta inquietação geral”.

ORG 1 - Também o escritor russo Fiodor Dostoievsky (1821-1881) e o poeta francês Stéphane Mallarmé (1842-1898) denunciaram, cada um a seu modo, esse mal-estar identificando-o com o aspecto normativo, determinista, quantitativamente controlado e desumano que haviam assumido as vidas e as formas de vida em decorrência da falência da otimista 'promessa' teleológica de cunho lógico-racionalista do projeto iluminista. Tal promessa havia reduzido friamente a felicidade e o bem-estar humanos aos estreitos limites das páginas do Ensaio filosófico sobre as probabilidades, no qual o matemático francês Pierre Simon Laplace (1749-1827) - com base no pressuposto de que o lançamento de um dado ideal, não viciado e não vicioso, poderia ser visto como um experimento aleatório inventou uma imagem determinista do futuro que o via, binariamente, como a face oposta do acaso. Havia sido com base nesse dado probabilístico ideal laplaciano que o filósofo e historiador francês Jules Michelet (1798-1874) havia também 'lançado ao ar' o seu confiante aforismo historicista de que "toda revolução é um lance de dados". Contrapondo-se, porém, à revolução determinista do dado laplaciano de Michelet, Mallarmé "lançou ao ar" um outro dado ético-estético contendo um número imprevisivel de faces em seu revolucionário poema intitulado "Um lance de dados jamais eliminará o acaso" 158 . Isso tudo, para não falar do Freud de $O$ mal-estar na civilização e de O futuro de uma ilusão.

ORG 3 - Pensando bem, acho mais razoável dizer que embora LW compartilhasse com Spengler, Freud e tantos outros um certo mal-estar endêmico que estaria levando a civilização ocidental à bancarrota, o ponto de vista de Heaton pode ajudar a esclarecer algumas semelhanças e dessemelhanças entre a prática da terapia gramatical wittgensteiniana e a prática da psicanálise freudiana:

$\mathbf{J H}^{159}$ - "É a teoria, e supostamente uma teoria científica, que dá autoridade para a prática da psicanálise [freudiana] e da TCB [Terapia Cognitiva Behaviorista], uma vez que, para ambas, essa autoridade está fora da prática. Se praticada sem teoria, parece que nós a

\footnotetext{
${ }^{157}$ Impressão causada pelo livro $A$ decadência do Ocidente de Oswald Spengler, na época da sua publicação original, sobre o filósofo Ernst Cassirer, expressa no seu livro O mito do Estado (CASSIRER, 1946, p. 269).

158 (MIGUEL, 2016b, p. 363).

159 (HEATON, 2010, p. 2-3, grifo nosso).
} 
praticamos cegamente, talvez usando apenas opinião. No entanto, a prática clínica da psicanálise não é logicamente dedutível de sua teoria. Ela não é também uma teoria dedutível da prática, uma vez que tanto a prática da psicanálise quanto a da terapia cognitiva são orientadas pela teoria. Freud e a maior parte dos terapeutas cognitivos acreditam no dogma metafísico que identifica "realidade" com "realidade científica", de modo que os requisitos para a inteligibilidade seriam algum tipo de processo causal, mecanismos tais como objetos e processos no inconsciente ou processos computacionais complexos. [...] Quando buscamos conhecimento e explicações para conflitos mentais, estamos presos em uma confusão cujo caráter não é transparente para nós. Somos movidos por um desejo de encontrar uma explicação para o conflito, como se isso nos permitisse curá-lo. Mas essa busca por uma resposta também é a força motriz do conflito; temos de nos libertar da tendência persistente de procurarmos respostas para todas as perguntas. São as condições em que os conflitos emergem e as confusões que surgem que necessitam atenção. Em vez de se buscar explicações psicológicas enraizadas nos conteúdos de um recipiente interno, chamado "a mente", nós podemos voltar a nossa atenção para a forma como estamos vendo as coisas, bem como para o modo como a linguagem está sendo usada".

ORG 3 - Esta diferença radical de base entre as práticas terapêuticas freudiana e wittgensteiniana que nos dá a ver Heaton ajudou-me a distinguir duas atitudes de LW que me soavam contraditórias, quais sejam, desconstruir Frazer, tal como ele o fez e aceitar aparentemente endossar o ponto de vista de Spengler acerca do mal-estar na civilização. Uma coisa é compartilhar com Spengler, Freud e todos os demais este mal-estar; coisa diferente, porém, é discordar deles em relação ao modo de se combater esse mal-estar gerado pela doença civilizatória. O modo como LW a combate, bem como o propósito que orienta esse combate são totalmente distintos tanto da proposta terapêutica freudiana quanto da teoria da história spengleriana.

ORG 1 - Agora concordo inteiramente com você. LW usa a metáfora da doença para se referir ao problema a ser levado ao divâ terapêutico e, por extensão, ao problema a ser investigado por uma historiografia terapêutica. Em ambos os casos, o problema assume a forma de uma doença, a fisiognomia de uma doença. Uma doença, após manifestar os seus sintomas, os seus sinais, evolui, mas não necessariamente no sentido de sua cura, no sentido teleológico de um progresso ético para um bem, para um bom, para um estado melhor, não, portanto, no sentido de uma historiografia whig, inglesa, em que uma doença é vista como um estado de barbárie, de infantilidade, de loucura, de selvageria, de selvagem, de ameríndios que deve progredir para uma cura, para um estado sadio e são do corpo. Parece que LW vê, então, uma doença como um mal-entendido semântico, como confusão semântica, como falta de clareza de sua fisiognomia, como falta de clareza de sua gramática. O seu remédio - nem determinista-otimista e nem determinista-catastrófico e, portanto, nem frazereano, nem spengleriano e nem freudiano - é o de exibir a apresentação panorâmica das conexões entre os sintomas, das conexões que mostram como e em que direções e sentidos os sintomas se transformam, que fisiognomia assumem, tendo em vista, porém, que eles podem ser vistos de outras maneiras, adquirir outras fisiognomias imprevisiveis e, portanto, não deterministas. 
ORG 2 - Acho que agora consigo ver com mais clareza em que poderia consistir a diferença entre uma historiografia morfológica orientada pela perspectiva cíclica e teleologicamente decadente de Spengler a uma historia morfológica terapêutico-gramatical. A conversa entre vocês me remeteu ao seguinte aforismo da cidade da linguagem de LW:

$\mathbf{L W}^{160}$ - "Não se incomode pelo fato de que as linguagens (2) e (8) consistem somente de ordens. Se você quiser dizer, por isso, que elas são incompletas, pergunte-se se nossa linguagem é completa; - se ela era completa antes do simbolismo químico e da notação infinitesimal lhe terem sido incorporados; pois estes são, por assim dizer, subúrbios da nossa linguagem. (E com quantas casas ou ruas começa uma cidade a ser uma cidade?). A nossa linguagem pode ser considerada como uma velha cidade: um emaranhado ${ }^{161}$ de ruelas e praças, casas velhas e novas, casas com anexos de épocas diferentes; e isto tudo circundado por um conjunto de novas periferias com ruas retas e regulares e com casas uniformes".

ORG 1 - A imagem do vitalismo morfológico de Spengler nos dá a ver morte e decadência como perda de vitalidade, ainda que não como de deterioramento físico ${ }^{162}$. Acho que é este aspecto da imagem spengleriana da história que de certo modo ecoa no aforismo da cidade da linguagem de LW. Mas as semelhanças entre as fisiognomias de uma historiografia morfológica spengleriana e de uma historiografia morfológica terapêutico-gramatical param por aí. O impulso vital casual - e não causal ou determinista - que movimenta a imagem de história no aforismo da linguagem nos dá a vếla como um conjunto sincrônico de acontecimentos em curso, e não como um acúmulo de ruínas do passado ou como um anúncio de decadência no futuro. A potência visualmente impulsiva e avassaladoramente tempestuosa desse aforismo - que apresenta panoramicamente, na instantaneidade sincrônica de um flash, a fisiognomia arquitetônico-urbanística, dinâmica e metamórfica da história constitutindose, entrelaçadamente, com os ilimitados jogos heterogêneos e completos de linguagem em expansão, morte e transformação - nos remete a obras típicas do movimento Sturm und Drang (Tempestade e Ímpeto). "Não pensem, vejam!"

\section{O ver como o olho terapêutico-gramatical vê}

ORGS - Dois modos de ver se confrontaram: o olho gramatical evolucionista e o olho gramatical morfológico. O olho direito confrontou o esquerdo e o esquerdo confrontou o direito. Supondo-se poder se ver mais potente, um viu o outro como míope. Confrontaramse?

\footnotetext{
160 (LW, IF-18).

161 Segundo Almeida, "na primeira versão manuscrita das IF, o manuscrito MS 142 (p. 12), Wittgenstein oscilou entre a visão da linguagem como Gewinkel, Gewirr ou Wirrwarr: todos substantivos que dão a ideia de "confusão, barafunda, desordem, desorientação", ou "labirinto". Mas, finalmente, a analogia foi efetivada com a palavra Gewinkel, que é um substantivo bastante ligado ao uso no campo da arquitetura e do urbanismo. Repare-se que, por força da própria analogia urbanística, também aqui se estabelece uma certa "visão de aspecto", e que ein Gewinkel, um recanto confuso de um bairro, poderia muito bem ter sido traduzido por "um labirinto", remetendo-nos diretamente para a seção $\int 203$ das IF.

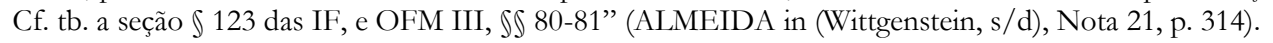

162 (GOMES, 2011, p. 4-5).
} 
ORGS - O olho terapêutico-gramatical - um outro modo de ver- confrontando-se a si mesmo, confronta-os. O que ele nos dá a ver? Por supor-se apenas poder ver, mas não se ver, o olho terapêutico-gramatical é um olho panorâmico de um pássaro atípico que está sempre entre... sempre a voar entre o passado e o futuro, a voar, portanto, por entre as temporalidades vitais sincrônicas das temporalidades vitais de todos os presentes, sem pousar em nenhuma delas. O olho do pássaro terapêutico-gramatical olha ao redor de todos os arredores vitais, de todas as formas de vida: olha, analisa, desconstrói e desconstrói-se.

ORGS - Afinal, como o olho terapêutico-gramatical vê?

ORG 1 - Veja que nas poucas vezes que o pensamento do LW tenta abrir um diálogo com a história, ele o faz, dialogando com Spengler, que escreveu um livro "proféticohistoriográfico" chamado "A Decadência do Ocidente: Esboço de uma Morfologia da História Universal”. Leia, por exemplo, na página XXXIV da introdução que o João Almeida faz à sua tradução das Investigações filosóficas, onde ele diz que a atitude de escrita terapêutica de LW teria sido inspirada em Freud, Göethe, Darwin, Weininger e Spengler, o que reforça a minha "conjectura intuitiva" de que não haveria propriamente uma "distinção de fundo" entre a abordagem terapêutica de um problema qualquer e uma abordagem terapêutico-historiográfica de um problema qualquer (no nosso caso, o problema do acaso). Talvez, a única diferença significativa entre esses dois projetos seria que, diferentemente de uma investigação filosófica, uma investigação historiográfica requereria "evidências empíricas". Penso, porém, que nada há que nos impeça lidarmos terapeuticamente com "evidências empíricas", ou melhor, com "arquivos ou fontes historiográficas" - e falo assim para nos afastarmos de uma imagem cientificista e empíricoverificacionista da históra - de uma maneira não-empírica, e também, não-semiótica. Uso aqui a palavra semiótica para me referir a possíveis historiografias inspiradas em perspectivas como as de Peirce, Umberto Eco e, sobretudo, de Carlo Ginzburg.

ORG 2 - Mas a historiografia morfológica de Spengler não está baseada numa imagem cíclica de temporalidade, ainda que não numa imagem universalista e absolutista da temporalidade, dado que em seu $A$ decadência do Ocidente ele não mais reivindica uma "história da humanidade" vista como totalidade, mas sim uma história, ou melhor, histórias de comunidades humanas organizadas em civilizaçôes? Uma historiografia terapêutica - além de desconstruir imagens de temporalidade autônoma, universal, transcendental e evolutiva linear - não deveria também desconstruir a imagem de temporalidade cíclica? Vejam o que diz LW em uma de suas críticas a Frazer, mais precisamente em relação à imagem de temporalidade evolutiva linear que orienta a historiografia whig de Frazer:

LW' $\mathbf{W}^{163}$ - "A explicação histórica, a explicação como uma hipótese da evolução, é apenas uma espécie de resumo dos dados - a sua sinopse. Assim como também é possível ver os dados na sua relação uns com os outros e resumi-los numa imagem geral, sem fazế-lo na forma de uma hipótese sobre a evolução temporal'.

163 (LW, 2007, p. 200, grifo nosso). 
ORG 1 - Você tem razão! O deslocamento a ser dado nessa desconstrução semântica da imagem de temporalidade universal, abstrata, evolutiva linear ou cíclica tende a colocar o jogo da significação num jogo de rastros conexivos que nos mostre que a construção de narrativas historiográficas significativas, como sugere esta fala de LW contra a imagem de temporalidade evolutiva linear que você nos apresenta, independe de imagens transcendentais de temporalidade, uma vez que tais imagens estão atreladas à imagem hegemônica de que a produção de significação estaria necessariamente atrelada à imagem cronológica de temporalidade, isto é, ao modo cronológico de organizar ou sequenciar os eventos com base na regra do que vem antes ou depois de. Tal regra já está, é claro, baseada na hipótese do princípio da causalidade de que todo efeito não só é produzido por uma causa, como também, de que esta causa pode e deve ser determinada... determinismo causal...

ORG 3 - Nublar essa imagem ilusória e a regra que a produz nos leva ao desafio de produção de narrativas significativas casuais, isto é, de narrativas que mostrem que significar independe de temporalizar transcendentalmente, absolutamente e causalmente, de modo que a imagem de uma narrativa terapeuticamente construída se assemelharia à imagem de uma narrativa causalmente desconstruida que nos desse a ver que significar são - sempre e inevitavelmenteatos vitais de temporalizar casualmente. Em outras palavras, não são os atos pessoais de significação - isto é, a voz do historiador de ofício - que dependeriam de uma temporalidade fixa e autônoma que lhe fosse imposta por uma voz universal transcendental ou por vozes constituídas em narrativas autorizadas (as vozes de outros historiadores de ofício, por exemplo), mas sim, as temporalidades casuais vitais é que se mostrariam dependentes de atos vitais casuais de significações.

ORG 2 - Você poderia nos dar um exemplo do que você está chamando de ato vital casual de significação?

ORG 3 - Um exemplo disso é o modo casual - e, portanto, não causal - como estamos propondo que se leia não só esta obra que organizamos, como também este capítulo introdutório no qual estamos nos interrogando terapeuticamente acerca da imagem de uma historiografia terapêutica. Não pergunte: - "o que é uma historiografia terapêutica?"

ORG 2 - Você esta querendo dižrer que o significado é um desejo de cada leitor, que ele varia em cada ato personalizado de leitura? E que, portanto, num jogo de linguagem de leitura de um texto, é sempre o leitor quem o significa casualmente? E que não faria sentido, portanto, o nosso desejo de que os leitores compreendam adequadamente este nosso texto introdutório e todos os demais?

ORG 3 - É você quem está significando assim a minha advertência. Embora o sumário apresente os títutos dos textos e os nomes de seus respectivos autores numa certa ordem, os capítulos não foram numerados justamente para que os leitores os leiam - ou leiam apenas os que lhes interessarem - na ordem que mais lhes parecer conveniente ou aprazível. O mesmo poderia ser dito da leitura deste nosso texto introdutório segmentado e não causalmente conectado, que intencionalmente - e não casualmente - está sendo escrito de um modo 
totalmente não convencional. Estariam os leitores, por esta razão, impedidos de significálo adequadamente?

ORG 1 - Aliás, é através de uma escrita segmentada e casual - isto é, não causalmente conectada que LW filosofa terapeuticamente. E quando lemos o texto do seu filosofar terapêutico é COMO $S E$ estivéssmos participando EM TEMPO REAL de uma sessão de terapia em que ele assumisse o papel de terapeuta. Talvez, também devesse ser este o aspecto fisiognômico mais característico de uma historiografia terapêutica, o aspecto que a distinguiria de todas as demais, qual seja, o seu aspecto casual. E então, uma historiografia terapêutica é como se fosse uma historiografia produzida em tempo real, isto é, orientada por uma imagem de temporalidade atual, e não de temporalidade potencial ou sequencial que caracteriza todos os modos colonizadores de bistoriografar. Não teria sido então por acaso que LW se deu conta de que havia inventado um novo método de filosofar, tematizando-o, justamente ao longo do seu processo de desconstrução da obra de Frazer. E a imagem da historiografia praticada por Fražer não se dá a ver como colonizadora apenas porque ela se mostra uma historiografia whig orientada pelos propósitos e valores modernos constitutivos da civilização europeia e americana que inventou e produæiu uma América à sua imagem e semelhança; mas sobretudo porque a narrativa historiográfica whig de Frazer é uma narrativa contínua que não deixa espaço para os silêncios, para o sem-sentido, para o mistério, enfim, para o acaso. Assim, a historiografia colonizadora de Frazer coloniza sobretudo porque deseja colonizar o silêncio, coloniz̧ar o mistério, colonizar o acaso. Ela preenche todas as lacunas porque é motivada pelo desejo cientificista de explicação causal, porque se deixa orientar pela hipótese de uma imagem colonizadora de temporalidade potencial que impõe uma imagem ilusória de continuidade à narrativa historiográfica.

LW - "Não há nada mais estúpido do que a tagarelice sobre a causa e o efeito nos livros de história; nada é mais inconsequente, menos bem pensado. Mas quem lhe poderia pôr um fim, só com dizê-lo? (Seria COMO SE pretendesse mudar, falando, o modo de as mulheres e os homens se vestirem) $)^{164}$.

LW - “O pensador assemelha-se muito ao desenhador cujo objetivo é apresentar todas as interrelações entre coisas" 165 .

LW - "As pessoas que perguntam constantemente "porquê??" S $\tilde{A O} C O M O$ os turistas que estão diante de um edifício a ler um guia e estão tão ocupados com a leitura histórica da sua construção, que isso os impede de ver o edifício" ${ }^{\text {166 }}$.

AM \& $\mathbf{C T}^{167}$ - "Sem dúvida, uma bela analogia arquitetônica que nos alerta para a nossa cegueira, a nossa perda de visibilidade do que está manifestamente estampado na superfície do edifício e claramente exposto à nossa visão".

\footnotetext{
164 (LW, 2000, p. 94, aforismo de 1947).

165 (LW, 2000, p. 27, aforismo de 1931).

166 (LW, 2000, p. 65, aforismo de 1941).

167 (MIGUEL \& TAMAYO, 2020, p. 10).
} 
ORG 3 - Acho que esta sua fala nos dá a ver um aspecto de uma historiografia terapêutica que nos ajuda a definir melhor a sua imagem, a sua fisiognomia. Penso que esta imagem poderia se definir ainda mais se a gente conseguisse visualizar imagens do que você está denominando de temporalidade atual em contraposição a temporalidade potencial. A imagem que me ocorre é a de que esta oposição seria da mesma ordem que a de imagem aristotélica de infinito potencial em contraposição à imagem cantoriana de infinito atual ${ }^{168}$. Pensem, por exemplo, em uma organização causal de infinitos eventos orientada pela imagem de temporalidade potencial ou contínua. Ela seria analogamente espelhada por uma narrativa historiográfica contínua, sem lacunas, cuja imagem se assemelharia à imagem da demonstração de um teorema que contivesse um número infinito de passos articulados mediante regras lógicas de inferência. Isso porque, a uma narrativa continuamente conectada de fatos à qual sempre poderíamos subtrair ou acrescentar novos fatos - à imagem de um segmento de reta que sempre poderia ser diminuído ou prolongado ilimitadamente -, corresponderia uma demonstração de um teorema em que as proposições são continuamente conectadas através de um certo número de passos que poderia ser sempre reduzido ou ampliado ilimitadamente. Pensem, agora, alternativamente, em uma organização casual de infinitos eventos orientada pela imagem de temporalidade atual, discreta ou descontinua. Ela seria analogamente espelhada por uma narrativa historiográfica descontínua e lacunar, cuja imagem se assemelharia à imagem da prova de um teorema que provasse a impossibilidade de se provar uma determinada fórmula bem formada dentro de um sistema axiomático-dedutivo. Uma prova, por assim dizer, que provasse a existência de lacunas ou silêncios lógicos dentro de um sistema axiomático que impedissem que a prova de fato provasse, isto é, que impedissem que o poder de persuasão da narrativa de uma prova se efetivasse por completo, ou melhor, que se efetivasse sem que se desconstruísse as imagens milenares de prova lógica e de lógica acordadas entre a comunidade de lógicos e de matemáticos pelo menos desde o advento dessa imagem axiomático-dedutiva da matemática nos livros de Euclides.

ORG 1 - Não pensem, vejam! Uma imagem escheriana ${ }^{169}$ de uma narrativa historiográfica contínua orientada por uma imagem gramatical de temporalidade potencial ou virtual que nos dá a ver a linha branca "costurando" os peixes, representadas pelas conexões causais entre os "fatos-peixes" de uma narrativa historiográfica. Já a imagem de uma escrita narrativa contínua nos é dada a ver pela perda da visibilidade panorâmica dos peixes, à medida que o nosso olho

\footnotetext{
168 Uma das características de algumas litografias de Escher é o poder de nos dar a ver conceitos matemáticos complexos e aparentemente paradoxais como, por exemplo, os conceitos de infinito potencial e infinito atual. "Até a primeira metade do século 19, a noção de infinito com que operavam os matemáticos era a de infinito potencial. Tanto Aristóteles, no século IV a. C, quanto Kant, no século XVIII, já haviam chamado a atenção sobre a impropriedade do uso da noção de infinito atual, devido ao fato dela levar a contradições, paradoxos ou antinomias em nosso raciocínio. Defenderam, então, o uso exclusivo da noção de infinito potencial, que está ligada à ideia de não-exauribilidade de uma grandeza, quer quando a ela vamos acrescentando partes indefinidamente, tornando-a sempre maior, quer quando a submetemos a divisões sucessivas indefinidamente, tornando-a cada vez menor. O que o matemático russo Georg F.L.P. Cantor (1845-1918) acabou fazendo foi mostrar a necessidade e importância do uso da noção de infinito atual no terreno da matemática, a qual está baseada na ideia de auto-reflexividade ou auto-representatividade. Essa ideia tornou possível a Cantor comparar conjuntos infinitos em matemática, chegando a conclusões assombrosas, à época, tais como, por exemplo, à ideia de que a quantidade de pontos de um pedaço qualquer de uma reta é igual à quantidade de pontos da reta toda, fato este que, flagrantemente, feria o postulado euclidiano de que o todo é sempre maior do que quaisquer de suas partes" (MIGUEL, 2007).

${ }^{169}$ Litografia (1959) intitulada “Limite circular III”" do artista gráfico holandês Maurits C. Escher (1898-1972). Disponível em no seguinte site, acessado em 18 de novembro de 2020.

(https://mcescher.com/gallery/mathematical/\#iLightbox[gallery_image_1]/12).
} 
os acompanha e tenta "pescá-los" no limite potencial infinito da linha circular do horizonte.

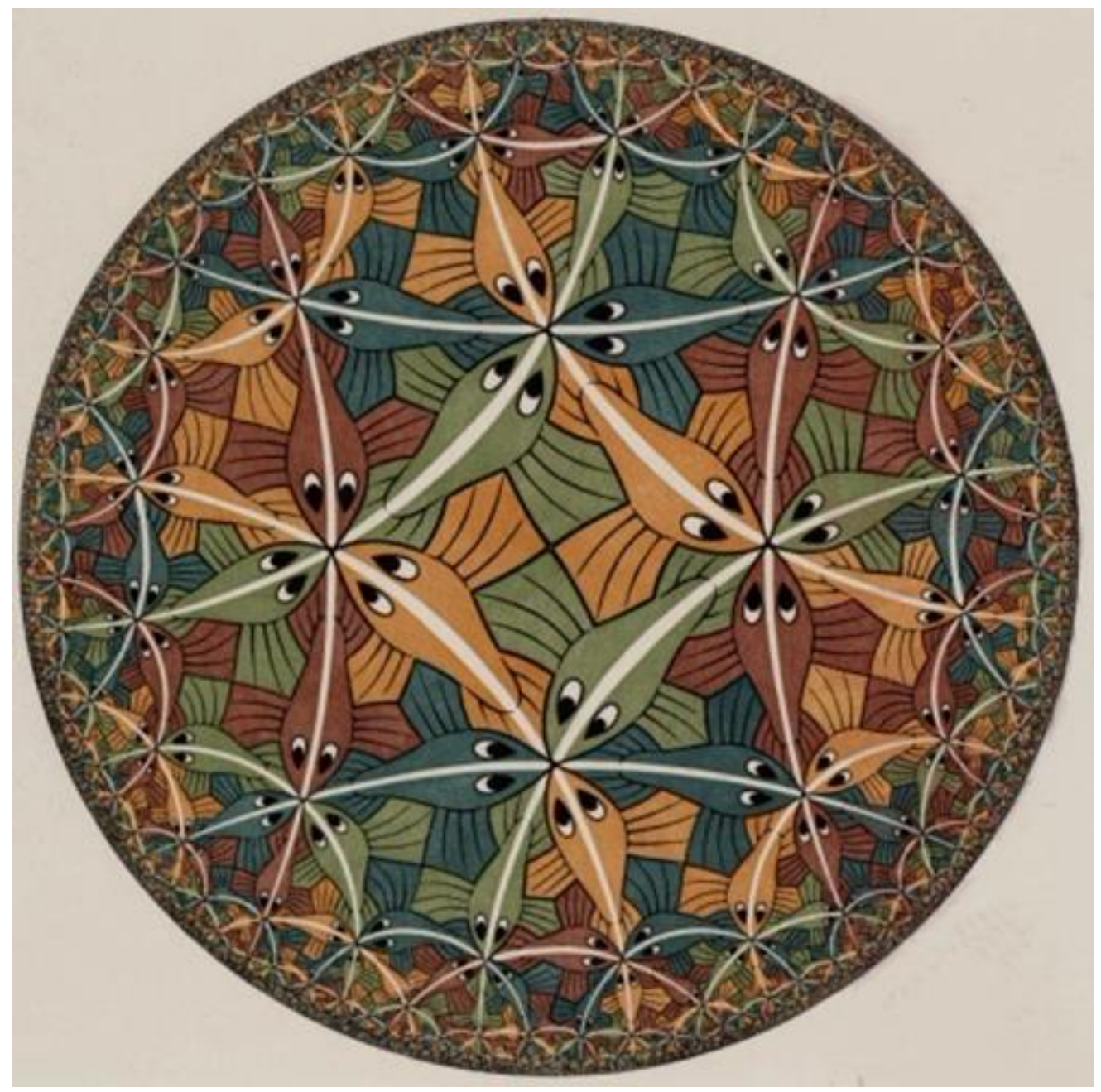

ORG 1 - Já o que nos é dado a ver panoramicamente nesta outra imagem também escheriana ${ }^{170}$, agora de uma narrativa historiográfico-terapêutica orientada por uma imagem gramatical de temporalidade real ou atual, são todos os objetos reais de uma sala de estar real, em tempo real. É como se tivesse uma visibilidade panorâmica atual, completa e simultânea - em suas posições interativas relativas que se mantém, porém, autônomas umas em relação às outras - de todas as diferentes formas de vida (os diferentes objetos contidos no interior da sala) que uma narrativa historiográfica se propõe a descrever.

\footnotetext{
${ }^{170}$ Litografia (1935) intitulada "Mão com uma esfera refletora" ou "Auto retrato em um espelho esférico" do artista gráfico holandês Maurits C. Escher (1898-1972). Disponível no site seguinte: (https://mcescher.com/gallery/mostpopular/\#iLightbox[gallery_image_1]/4), acessado em 18/11/2020.
} 


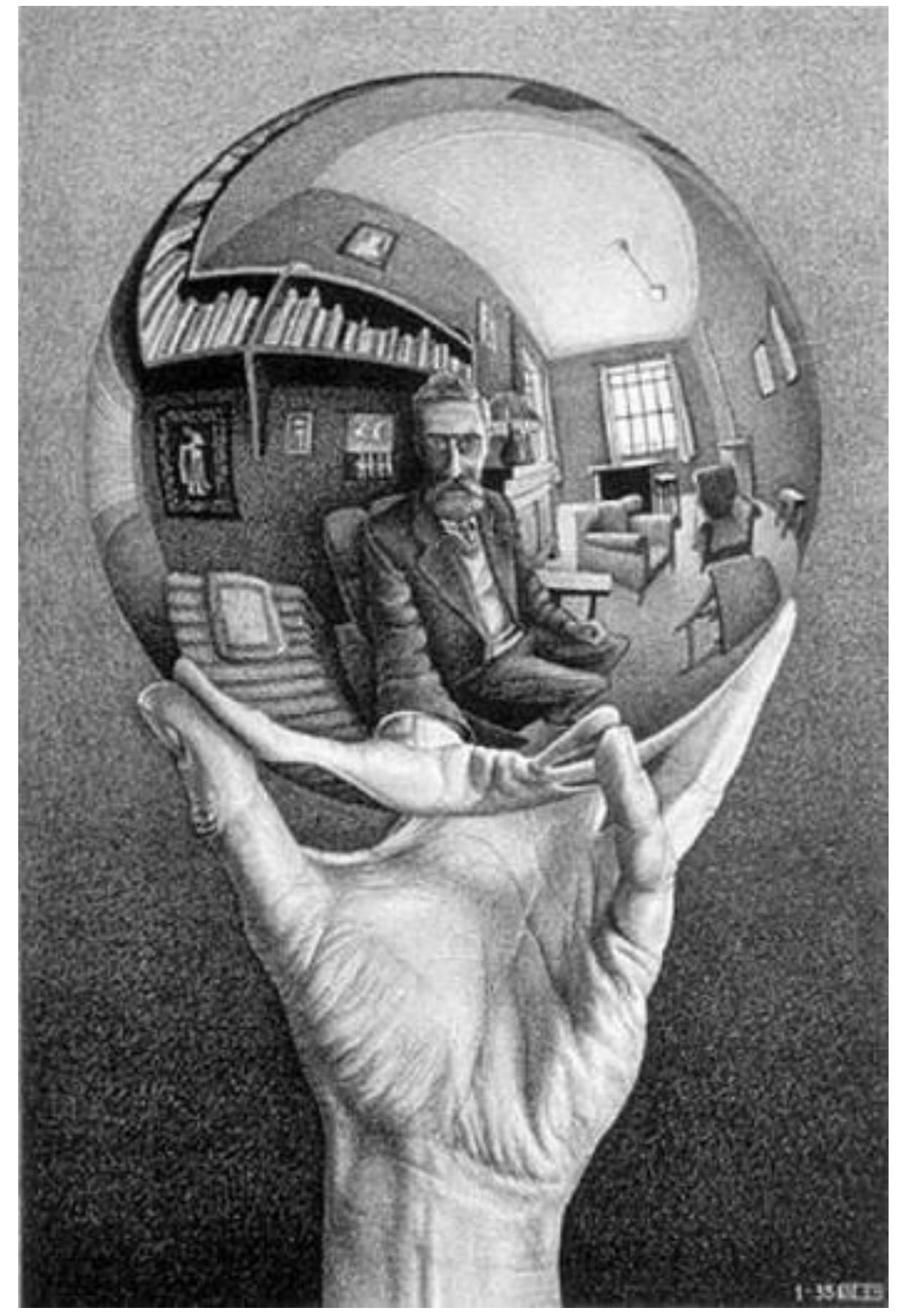

$\mathbf{L W}^{171}$ - "[...] Pois a claridade a que aspiramos é certamente completa. Mas isso só significa que os problemas filosóficos devem desaparecer completamente. A real descoberta é a que me torna capaz de interromper o filosofar quando quiser. - Que dá descanso à filosofia, de modo que ela não é mais açoitada com perguntas que colocam a si mesma em questão. - Senão que se mostra agora, por exemplos, um método, e a sequência desses exemplos pode ser interrompida."

ORG 2 - Quero voltar à imagem de uma narrativa historiográfica descontínua e lacunar que nos foi aqui apresentada por ORG 3. Quando você diz que essa imagem se assemelharia à imagem da prova de um teorema que provasse a impossibilidade de se provar uma determinada fórmula

${ }^{171}$ (LW, s/d, IF-33, p. 96). 
bem formada dentro de um sistema axiomático-dedutivo, esta analogia me remeteu a um artigo recente da pesquisadora wittgensteiniana Juliet Floyd, no qual ela argumenta em favor da tese de que a escrita terapêutica segmentada, lacunar e polifônica que LW passa a utilizar nas Investigações deveria ser vista como o impacto gerado sobre a concepção de lógica de LW da leitura do artigo "On computable numbers"172 ("Sobre números computáveis") escrito pelo matemático inglês Alan Turing. Ouçamos Floyd:

$\mathbf{J F}^{173}$ - "A minha tese é a de que a análise que faz Turing da natureza de uma "passagem" de uma prova em lógica em seu On computable numbers permitiu a LW ver tal análise como um argumento suficientemente forte para se rever a natureza da lógica. O artigo de Turing estabelece que não há um procedimento por meio do qual possamos decidir sobre questões do tipo Sim ou Não, como aquelas que decorrem de um conjunto de axiomas: esta é a sua prova (negativa) do Entscheidungsproblem de Hilbert. Por outro lado, existem muitos procedimentos passo a passo entrelaçados e reconhecíveis. Mas eles são, por assim dizer, as fibras "sobrepostas" que mantêm conceitualmente unificado o domínio da lógica como uma totalidade. Pareceu, portanto, perfeitamente lógico para LW renunciar ao ideal de uma apresentação "natural", "bem ordenada" ou "sem lacunas" de seus pensamentos nas IF. Um álbum de instantâneos parciais se adapta melhor à sua visão. O ideal "livre de lacunas" é precisamente aquele aludido explicitamente nas IF como uma forma de apresentação de suas ideias que $L W$ percebeu que teve de renunciar (Prefácio IF, 67). Nem a concepção de Turing, nem a de LW oferecem uma apresentação "livre de lacunas" [sem intervalos, contínua] da lógica em geral. As estruturas de comando em termos das quais Turing apresentou suas "máquinas" são uma reminiscência das tabelas de comando do Livro Marrom de LW. De um certo ponto de vista, elas são estáticas, meras quíntuplas de signos. No entanto, cada um representa, do ponto de vista do usuário final, um processo, algo dinâmico (como as apresentações de Wittgenstein de jogos de linguagem). O que Turing fez, por meio desse dinamismo, foi nos dar uma análise penetrante precisamente daquele aspecto sem lacunas da lógica que Frege e Russell procuraram explicitamente nas provas em Lógica. Ele manifesta rigorosamente os limites internos dessa noção".

ORG 2 - Floyd também defende, neste mesmo artigo, que também o conceito de formas de vida teria passado a assumir um papel de maior destaque no pensamento de LW justamente em decorrência da leitura que fez desse artigo de Turing, desencorajando, de certo modo, as imagens culturais da noção wittgensteiniana de formas de vida, reinserido-a na tradição lógica do pensamento de LW:

\footnotetext{
${ }^{172}$ Neste artigo, Turing dá uma resposta negativa ao confiante desejo do matemático alemão David Hilbert de que a matemática seria o reino do decidível, mais precisamente, fornece uma prova ao Entscheidungsproblem (termo alemão para "problema de decisão") que havia sido levantado por Hilbert. O problema da decisão interroga sobre a possibilidade de se achar um algoritmo genérico para determinar se um dado enunciado da lógica de primeira ordem pode ser provado. Em 1936, no referido artigo, Turing mostrou que é impossível decidir algoritmicamente se um enunciado na lógica de primeira ordem é verdadeiro ou falso. Isso significa que cada problema de decidibilidade deveria ser tratado e investigado separadamente, pois não se poderia dar uma prova geral de decidibilidade que abarcasse todos os problemas de decisão simultaneamente.

173 (FLOYD, 2016, p. 14, grifo nosso).
} 
$\mathbf{J F}^{174}$ - "Para reconsiderar Lebensformen (formas de vida) desta forma [em uma linha de continuidade com a tradição lógica do pensamento de LW], como um produto final do método regressivo, eu imponho uma cronologia do desenvolvimento do pensamento de LW. Valorizo o fato de que Lebensform entrou no pensamento de LW em um momento crucial, o período de 1936-7. Esta foi a época em que ele produziu os dois primeiros rascunhos das Investigações filosóficas e passou a adotar o seu estilo maduro posterior de escrita. Por que Lebensform entra em sua escrita, então? Proponho uma resposta (pode haver outras). Durante este período - não temos certeza de exatamente quando, mas poderia ter sido a qualquer momento entre a primavera de 1936 e a primavera de 1937 - LW teve acesso ao artigo de Alan Turing "On computable numbers: com uma aplicação para o Entscheidungsproblem". No verão de 1937, ele se encontrou com Turing e discutiu o artigo com ele, incorporando observações no seu manuscrito, ao mesmo tempo em que completou a chamada Frühversion, isto é, a versão anterior das IF. Se levarmos essa história cronológica a sério, e conjeturarmos acerca do impacto da leitura deste artigo sobre a concepção da natureza da lógica de LW, veremos como e por que as formas de vida passaram a desempenhar um certo papel em suas obras posteriores".

ORG 3 - Diferentemente de Floyd, o professor alemão Gunter Gebauer e o professor italiano Franco Lo Piparo acusam o que denominam de uma virada antropológica no pensamento de LW, exatamente no mesmo período a que se refere Floyd. Além disso, eles atribuem essa virada mais propriamente como decorrente da nova imagem que LW passa a fazer da linguagem em relação àquela do Tractatus, sobretudo devido ao impacto que teria exercido a noção gramsciana de praxis sobre o pensamento de $\mathrm{LW}$. Gebauer destaca o fato de que a virada para uma concepção materialista e praxiológica do mundo em LW teria sido fortalecida, sobretudo, pelos cerca de 238 encontros que Wittgenstein teria tido - entre fevereiro de 1929 e novembro de 1950 - com o economista italiano Piero Sraffa, que foi também quem possibilitou a preservação e publicação dos escritos de Antonio Gramsci - os Cadernos do cárcere - produzidos na prisão, após a sua morte. Teria também contribuído para esta virada, segundo Gebauer, as inúmeras discussões travadas, na Cambridge dos anos 1930, entre grupos de orientação marxista, dentre eles, os de orientação gramsciana ${ }^{175}$. Por sua vez, Franco Lo Piparo, professor de filosofia da linguagem da Universidade de Palermo e estudioso tanto da obra de Antonio Gramsci quanto da de Wittgenstein, no livro intitulado Il professor Gramsci e Wittgenstein: il linguaggio e il potere ${ }^{176}$, também destaca esta virada antropológica no pensamento do filósofo austríaco, induzida pelo pensamento gramsciano. Vamos ouvi-lo:

FLP" ${ }^{177}$ - "A virada antropológica (mas que também poderia ser chamada historicista) de LW, induzida por Gramsci através de Sraffa, tem uma data certa: 1934-1936. [...] Em Gramsci não aparecem os termos "jogos de linguagem" e "formas de vida". No entanto, é central na filosofia gramsciana a noção de praxis, termo e conceito que entrou no léxico teórico de LW a partir de 1936: vê-la como uma sugestão, não apenas terminológica, de Sraffa-

\footnotetext{
174 (FLOYD, 2016, p. 8-9, grifo nosso).

175 (GEBAUER, 2013, p. 66-67).

176 (LO PIPARO, 2014).

177 (LO PIPARO, 2014, p. 74-75, grifo nosso).
} 
Gramsci me parece lícito. Em apontamentos manuscritos de 21 e 22 de outubro de 1937, Wittgenstein observava: "A origem e a forma primitiva dos jogos de linguagem é uma reação. Somente com base nela é que formas mais complicadas de linguagem podem surgir. A linguagem - quero dizer - é um refinamento. No princípio era a ação". [...] "Uma característica de nossa linguagem é que ela crescre sobre um terreno de forma de vida estável, de modo regular de agir. A sua função é antes de tudo determinada pelo agir que a acompanha". [...] "A forma básica (Grundform) do jogo deve ser aquela em que se age".

ORG 1 - Não vejo como incompatíveis as imagens de Floyd, Gebauer e Lo Piparo sobre o rumo que teria tomado o pensamento e a escrita terapêutica de LW a partir da virada ocorrida a partir de meados da década de 1930, ainda que eles argumentem de modos diversos em relação às motivações da virada. Penso que, quando sobrepostas como num retrato compósito, tais imagens produzem uma outra de melhor definição sobre a fisiognomia de uma bistoriografia terapêutico-gramatical, tanto como uma atitude orientadora de uma investigação historiográfica propriamente dita, quanto como um modo de apresentação escrita segmentada e lacunar dessa investigação.

ORG 2 - Tendo a discordar de você. Penso que ver a virada como antropológicopraxiológica ou como de natureza estritamente lógica produz efeitos bem diferentes sobre a fisiognomia de uma historiografia terapêutico-gramatical.

ORG 3 - Sobretudo se nos atentarmos para o fato de que Floyd parece fazer uma imagem dessa virada lógico-turinguiana de LW, vendo-a meramente como uma virada não psicológica no modo de LW significar formas de vida e visão de aspectos. Vamos chamá-la novamente:

$\mathbf{J F}^{178}$ - "Wittgenstein tende cada vez mais, com o passar do tempo, a enfatizar as várias maneiras pelas quais os aspectos surgem e nos atingem, bem como a variedade de modos de se ligar cadeias de pensamentos. Ele explora aqui as diferenças entre a nossa capacidade de estabelecer conexões relativamente às de outras formas de vida (cães e coelhos), mas o que está em jogo aqui são nossas amarras, nossos conceitos ("história natural", no sentido de Wittgenstein). O aspecto é uma noção lógica, não psicológica. A metáfora de uma cadeia se conecta naturalmente, então, não apenas à "forma" mas também à "vida". A grande "corrente" do Ser não existe mais, como em Lovejoy, como uma estrutura taxonômica ordenada e livre de lacunas na qual todas possibilidades são eventualmente realizadas. A cadeia passa a ser vista como uma série de processos e eventos fluidos, embora estruturados, de formações de formações da (e na) vida, necessidades embutidas em um mundo de contingências, em que podemos fazer, refazer e modelar, e o que se segue disso sobre possibilidades para outras formas. Tais procedimentos ou possibilidades em cadeia que seguimos, reunimos e compartilhamos, proporcionam oportunidades para exercícios de caracterização, análise e simplicidade que são, eles próprios, projetados para caracterizar, analisar e simplificar as noções de caracterização, análise e simplificação. Mais tarde, as cadeias do LW maduro não têm um fim ou um início absolutos, em termos de um lugar fixo de referência: resta

178 (FLOYD, 2016, p. 73-74, grifo nosso). 
em geral apenas o esquemático "começa" e "termina", resta apenas a possibilidade de ligação (com palavras, pensamentos, ações, ruas, gestos, procedimentos...) enquanto tais. A ressonância do trabalho de 1952 de Turing sobre a morfogênese é impressionante".

ORG 2 - Parece-me que esta virada lógico-turinguiana de LW, de acordo com Floyd, tende mais a logicizar as formas de vida e os nossos modos de ver como, de ver aspectos, de estabelecer conexões do que vitalizar a lógica. E essa imagem lógico-turinguiana do ver como, da vida e das formas de vida acaba também por construir não propriamente um $L W$ antropológico ou um LW vitalista, mas sim um $L W$ morfológico, mais voltado para a forma lógica da vida do que para a vida lógica da forma. Assim, a virada do LW do Tractatus estaria para o LW das Investigações assim como a forma lógica da proposição estaria para a forma lógica da vida. A rigor, então, o LW da virada lógico-turinguiana não vira ao avesso nem o tapete da lógica e nem o tapete da vida. Não vira nada. Apenas recorta em pedaços a narrativa do tapete da vida... Penso, porém, que a própria e sensível imagem de LW que nos dá a ver a vida COMO SE fosse um tapete nos dá também a vê-la, não de um modo unitário, mas como um compósito de fibras - um compósito de formas de vida - que se entrelaçam, se intersecionam, se aproximam, se afastam, mantendo, porém, cada uma delas uma forma idiossincrática nem racional, nem irracional, nem lógica, nem sociológica, nem antropológica, mas tão somente praxiológica - de organizar a vida, de produzir, reproduzir e transformar a vida. Ver uma forma de vida como praxiológica significa vê-la orientada por uma lógica das ações e interações que humanos estabelecem entre si e com os demais seres naturais e tecnológicos, o que é muito diferente de meramente projetar uma lógica humanista - porque formal, proposicional e produzida exclusivamente por humanos - sobre as diferentes formas de vida que se entretecem na produção do tapete da vida. Penso, então, que Floyd projeta indevidamente sobre o olho gramatical wittgensteiniano do "Não pense, veja?" o olhar (morfo)lógico de Turing, reduzindo as gramáticas praxiológicas que orientam as ações dos participantes de jogos de linguagem que se jogam nas formas de vida à gramática praxiológico-axiomática que orienta os jogos lógico-proposicionais de linguagem. A seguinte passagem das Observações sobre os fundamentos da matemática nos mostra que LW estava ciente de que não é uma técnica - isto é, a gramática que orienta a transformação praxiológica de um conjunto de seres em outros seres - que se assenta numa proposição, mas sim, uma proposição que se assenta numa técnica:

LW"179 - "A proposição repousa em uma técnica. E, se você quiser, em fatos físicos e psicológicos que essa técnica torna possível. Mas o seu sentido não é, por esse motivo, expressar essas condições. Diferentemente da proposição normativa "Este trecho tem 240 polegadas", a proposição normativa "12 polegadas $=1$ pé" não diz que os padrões são suficientemente rígidos ou que todos nós contamos e calculamos do mesmo modo. $A$ proposição repousa em uma técnica, mas não a descreve."

ORG 3 - Quero fazer uma crítica ao ponto de vista de Floyd. Penso que ela supervaloriza o impacto da obra de Turing sobre a de LW, mas não dá o mesmo destaque para o fato de que LW questionava em muitos aspectos o modo de pensar de Turing, sobretudo o seu

179 (LW, s/d, Parte VII, $\$ 1$, p. 416-417, grifo nosso). 
modo de ver a matemática proposicionalmente organizada e a sua relação com o mundo praxiológico, isto é, com as formas de vida. Vejam, alternativamente, como Lo Piparo vê a virada matemática de LW, como decorrência do que ele denomina virada sócio-antropológica, mas que eu preferiria denominar virada praxiológica, acusando nela, porém, um aspecto paradoxal:

FLP $^{180}$ - "Depois da virada, também a ideia de que a matemática possa ser adequadamente representada mediante a imagem do jogo visto como cálculo sintático autônomo é submetida a exame crítico: “às vezes é útil comparar a matemática a um jogo e às vezes é enganador. [...] Uma das razões pelas quais se compara a matemática a um jogo é que se pode mostrar que ela é, em certo sentido, arbitrária (o que é, em certo aspecto, enganador e perigoso)" ${ }^{\prime 181}$. Nos anos seguintes, também a noção de cálculo passa de uma concepção exclusivamente sintática para uma socio-antropológica: "Poderia haver aritmética sem a concordância daquele que calcula? Poderia um ser humano, sozinho, calcular? Poderia alguém sozinho seguir uma regra? Seriam estas perguntas semelhantes a esta: "poderia um único indivíduo fazer comércio?" ${ }^{182}$. Entretanto, se a noção de cálculo passou a ser redefinida em um sentido socio-antropológico, o LW dos últimos anos, traz uma conclusão paradoxal: a máquina de calcular não calcula e não faz matemática. [Ele disse isto num aforismo que se conclui assim]: "Quero dizer: é essencial para a matemática que sejam também feitos usos civis de seus signos. É o uso que se faz fora da matemática e, portanto, os significados (Bedeutung) dos signos, aquilo que transforma em matemática o jogo de signos. Portanto, assim como não é uma inferência lógica se transformo uma estrutura em outra (uma arrumação de cadeiras, talvez, em outra), se essa arrumação não tiver um uso linguístico fora dessa transformação"183. A passagem de uma concepşão sintático-calculista para uma sócioantropológica da noção de jogos de linguagem aparece nos anos imediatamente precedentes à versão manuscrita de 1936 das Investigações. São os anos em que Sraffa lê os Cadernos de Gramsci. Nas lições de 1933-34, constantes do Livro Azul, a noção de jogos de linguagem é ainda uma noção que oscila entre uma concepção calculista e uma concepção antropológico-culturalista. [...] Jogos de linguagem não é ainda o esquema conceptual que explica as práticas culturais e verbais, mas um modelo simplificado "da nossa complicadíssima linguagem cotidiana".

ORG 3 - Detalhando melhor a minha crítica ao ponto de vista de Floyd, eu diria que a conclusão paradoxal de LW, tão bem acusada por Lo Piparo, de que a máquina de calcular não calcula e não faz matemática provavelmente não seria vista por ela como paradoxal, porque a hipótese lógica, ainda que não logicisita, que a orientou na produção do seu texto a impede de realizar uma análise do modo como o diálogo entre LW e Turing e, mais particularmente, do modo como LW via as máquinas de Turing, sob uma perspectiva sócio-antropológico-culturalista que ela já descarta de antemão. Penso que, em vez de acusar o paradoxo acusado por Lo Piparo, ela preferiria, supostamente, justificar a sua tese de que, para LW, as máquinas de Turing efetivamente calculam mediante dois significados

\footnotetext{
180 (LO PIPARO, 2014, p. 73-74, grifo nosso).

181 (LW, LFM-15, 1939).

182 (LW, OFM-VI-\$45).

183 (LW, OFM-V-\$2).
} 
diferentes que a palavra máquina - máquina teórica ou máquina real - poderia assumir em dois momentos qualitativamente diferentes - um teórico e outro prático - dos trabalhos de Turing, quais sejam, aquele em que ocorreu a escrita do seu artigo de 1936, no qual ele apresentaria os fundamentos da teoria da computação, e aquele ocorrido durante o período da segunda guerra mundial, no qual o seu trabalho apresenta uma virada praxiológica voltada ao desenvolvimento efetivo de "propostas de engenharia"184. É este, por exemplo, o argumento que Alfonso Flórez aciona para justificar o aspecto paradoxal da passagem das OFM a que se refere Lo Piparo:

$\mathbf{A F}^{185}$ - "Este logro, en parte teórico, en parte técnico, seria el desencadenante del cambio de posición de Turing, que giró entonces en forma definitiva hacia el proyecto de la inteligencia mecánica. Pero el comentario de LW sobre las máquinas de Turing solo puede interpretarse dentro del contexto del artículo de 1936 (Turing, 1936), es decir, cuando estas máquinas son sólo una construcción teórica, gracias a la cual se quiere abordar el problema de la decisión de Hilbert. No me parece, por tanto, que sea sostenible una lectura de las expresiones de LW acerca de las máquinas que calculan como si pudieran hacer referencia a las máquinas de Turing".

ORG 3 - Assim, para justificar a sua tese, Flórez mantém, mesmo após a virada matemática de LW, a sua imagem sintático-calculista da matemática - e sua correspondente distinção entre "matemática pura" ou "teórica" e "matemática aplicada" ou "engenharia" - e desdobra a imagem turinguiana de máquina em "máquinas teóricas" ou "matemáticas" e "máquinas reais".

ORG 1 - De minha parte, eu gostaria que você, ORG 3, me esclarecesse o que quis dizer com olhar "(morfo)lógico de Turing"? Teria ele alguma ligação com a afirmação da última fala de Floyd que destaquei aqui, que termina dizendo ser impressionante a ressonância do trabalho de 1952 de Turing referente à morfogênese sobre o modo como LW reconceptualiza a noção de aspecto?

ORG 2 - Acho que o biólogo hindu Vidyanand Nanjundiah pode ajudar a esclarecer esta questão. Li recentemente o seu artigo intitulado Alan Turing and "The Chemical Basis of Morphogenesis”. Ouçam o que ele diz acerca da motivação de Turing para se envolver em uma investigação biológica, área que ele pouco ou nada dominava:

$\mathbf{V N}^{186}$ - Em "The Chemical Basis of Morphogenesis" Turing tentou demonstrar que sistemas que reagem e difundem mutuamente produtos químicos poderiam ser usados para ilustrar a origem misteriosa da forma biológica dentro de uma estrutura anteriormente sem formapor exemplo, dentro de um embrião em desenvolvimento. Sua motivação para fazer isso parece ter sido refutar o "argumento do design" de uma vez por todas, eventualmente por

\footnotetext{
${ }^{184} \mathrm{Na}$ verdade, esta imagem de dois modos distintos de significar a palavra "máquina", por parte de Turing, em dois momentos distintos de seu trabalho, é construída por Flórez (2003, p. 211) e está sendo aqui acionada por ORG 3 como um argumento hipotético desestabilizador do ponto de vista de Floyd acerca da virada no pensamento de LW na década de 1930. Floyd, porém, não usa esta imagem e nem dialoga com o texto de Flórez. 185 (FLÓREZ, 2003, p. 211-212, grifo nosso).

186 (NANJUNDIAH, 2002, p. 34-35, grifo nosso).
} 
meio de simulações do funcionamento do cérebro em analogia com o funcionamento do cérebro eletrônico de um computador. Como é bem conhecido, o "argumento do design" refere-se à metáfora de William Paley do relógio e do relojoeiro. A complexidade da construção de um relógio, a interdependência de suas partes componentes e a função evidente que possui - a de registrar a passagem do tempo - significa que ele não pode ter sido inventado por acaso; um relojoeiro deve ter construído de acordo com um plano. É muito menos provável, então, que um organismo vivo, muito mais complexo em sua construção e funcionamento do que um mero relógio, pudesse ter surgido sem um projetista. Alguém poderia pensar que o poder explicativo da seleção natural - o "Relojoeiro Cego" - teria dado ao argumento do design um golpe fatal. No entanto, variações do argumento de Paley continuam a sobreviver em diferentes formas. $O$ mecanismo de desenvolvimento da forma durante a embriogênese está ainda hoje envolto em obscuridade e ignorância suficientes para o pensamento mistico e vitalista prosperar. Deve-se notar que a tentativa de Turing de se opor ao "argumento do design" foi baseada na lei natural, não na evolução, e esta distinção é importante. O foco de atenção de Turing foi a dramática quebra de simetria que ocorre, aparentemente em uma estrutura homogênea e isotrópica (o ovo fertilizado) e sem quaisquer pistas externas. Isso foi algo que aconteceu vez após vez durante a embriogênese. Ele provou que era possível montar reações químicas plausíveis que, quando combinadas com a difusão, davam conta do recado. Pelo menos duas espécies químicas eram necessárias e elas deveriam ser capazes de estimular ou inibir a síntese uma da outra. No geral, as reações químicas deveriam ser não lineares. Em linguagem matemática, Turing demonstrou que dado o conjunto correto de parâmetros (taxas de reação, feedbacks, coeficientes de difusão), o estado uniforme inicial era instável com respeito a perturbações não homogêneas de ocorrência espontânea. [...] Turing acreditava que o problema mais importante da biologia contemporânea era explicar o padrão e a forma. Entretanto, a Morfogênese não lida, de modo algum, com a geração da forma, mas com a formação de padrões. Os tipos de estruturas que devem ser explicados são a distribuição de manchas em um leopardo, listras em uma zebra, braços em uma estrela de peixe ou tentáculos em uma hidra, e não a forma de um peixe ou elefante. [...] À primeira vista, as abordagens desse problema por Turing e um seu predecessor, D'Arcy Thompson, pareciam não se assemelhar. Ambas eram no fundo não evolucionárias; a de Thompson, era explicitamente antidarwinista. Sua objeção mais profunda ao pensamento darwiniano parece ter sido que, para ele, o organismo era um todo, um todo, cujo corpo físico era marcado por uma atenção aos detalhes que era inevitável para qualquer estrutura física complexa cuja estabilidade tinha que ser assegurada - por exemplo, uma ponte. As proporções relativas de tal estrutura tinham que obedecer estritamente às regras impostas pelos critérios da engenharia mecânica aos corpos físicos. Em particular, não se poderia mexer em uma parte da estrutura sem afetar a eficiência funcional do todo. Na linguagem da física, as interações entre as partes seriam fortes. Assim, para ele, a afirmação supostamente darwiniana - de que as modificações evolutivas poderiam resultar em mudanças graduais na forma e conformação de uma parte do corpo sem afetar todas as outras, ou no máximo afetá-las apenas ligeiramente - estava em contradição com as leis de equilíbrio que devem governar todas as configurações da matéria, portanto também da matéria viva. Noções como seleção natural modificando a forma de uma mandíbula ou o ângulo de uma barbatana, mas não 
fazendo nada mais, eram absurdas, porque essas eram partes de um corpo que não faziam sentido exceto no contexto do todo".

ORG 2 - Não sei se vocês estão observando, mas o propósito não biológico que levou Turing a conduzir a investigação de um problema embriológico acabou condicionando inclusive a sua escolha de uma abordagem pouco convencional para investigá-lo, uma abordagem, digamos assim, holistica e não-evolucionista, diferentemente daquela que inspira a maior parte dos programas de pesquisa na embriologia contemporânea. Continuemos ouvindo Nanjundiah:

VN ${ }^{187}$ - "Além disso, perguntava-se Turing, se as considerações mecânicas foram suficientes para explicar as mudanças dramáticas na forma de um embrião à medida que se desenvolvia em um adulto, por que considerações semelhantes não seriam úteis para explicar as diferenças mais leves nas formas entre os indivíduos de uma espécie e outra? É verdade que Turing não diz nada explicitamente contra a seleção natural. Ao mesmo tempo, uma abordagem que se baseia na física e na química aplicada "globalmente" - ao tecido em sua totalidade - é bastante diferente de outra que se baseia na suposição de que os genes e produtos gênicos são os elementos básicos que entram na forma e padrão de construção. A última abordagem, local, típica na biologia do desenvolvimento contemporânea, exige um programa de pesquisa que se dedique a perguntar o que torna um determinado gene ativo em uma determinada célula em um determinado momento. Isso não é o mesmo que perguntar quais padrões globais de tecido são consistentes com uma combinação particular de produtos genéticos. A visualização local é uma visualização estática ou uma sucessão de visualizacõoes estáticas; ela constitui a base da maioria das pesquisas experimentais. A visão global é inerentemente dinâmica. A maneira baseada em genes de estudar padrões tem uma suposição implícita embutida nela: a saber, que os genes cujas atividades estão subjacentes ao desenvolvimento de um padrão particular também testificam, em virtude do fato de serem genes, que o padrão deve ser um produto de evolução. Ao dizer isso, tenho em mente a imagem comumente expressa da evolução como algo que "em última instância" ocorre no espaço genético. Como corolário, se um padrão biológico cujos correlatos genéticos são razoavelmente bem compreendidos exibir variações dentro da mesma espécie ou em espécies diferentes, há esperança de que os estudos de sequenciamento de DNA (digamos) possam lançar luz sobre as mudanças genéticas que acompanharam sua evolução. Diante disso, essa esperança não existe no caso de um padrão que é entendido como consequência de uma instabilidade de Turing. [...] Assim, $a$ atitude de Turing para a formação de padrão exemplificou uma abordagem não evolutiva. Pode valer a pena reiterar brevemente os dois aspectos nos quais as explicações evolucionárias diferem radicalmente das explicações físicas não evolutivas. Em primeiro lugar, uma explicação física de uma entidade implica um entendimento (em qualquer nível que seja exigido) daquela entidade individual e daquela entidade sozinha. No mundo real, o resto do universo é considerado um incômodo; seus efeitos de interferência devem ser minimizados em laboratório. Isso se reflete na tentativa do físico experimental de "preparar" e "isolar" um "sistema". Com isso, e com habilidade e sorte, espera-se entender tudo o que for

187 (NANJUNDIAH, 2002, p. 34-35, grifo nosso). 
possível sobre a entidade de interesse. A maneira como o biólogo evolucionista explica um organismo vivo não poderia ser mais diferente. Para começar, o meio ambiente do organismo está longe de ser algo cuja influência deve ser minimizada, visto que mascara a essência de seu ser. Na verdade, o meio ambiente é um elemento central na definição do que é o organismo. Mais do que isso, para um evolucionista, o objeto "mínimo" que pode ser compreendido não é o organismo individual de forma alguma, mas sim toda uma população de organismos, juntos constituindo uma classe reconhecível (a espécie) à qual pertence o organismo inicial. Em segundo lugar, por causa da evolução, as criaturas vivas são produtos da história. Eles fazem sentido - são capazes de ser compreendidos - apenas no contexto de sua história. Tal como acontece com as explicações históricas em geral, os acidentes e caprichos do acaso, para não mencionar outras histórias, precisam ser levados em consideração. Por outro lado, lutar por uma explicação evolucionária de um objeto físico seria como dizer que, para entender um átomo de hidrogênio, é preciso examinar todos os átomos de hidrogênio do universo e, além disso, perguntar como eles chegaram a esse ponto. Seria um exercício tolo. Quase nenhum biólogo parece ter lido o Morfogênese de Turing nos primeiros anos, ou se o leu, não o citaram”.

ORG 1 - Muito interessante esse conjunto de ocorrências casuais que nos levaram a definir melhor a fisiognomia de uma historiografia terapêutico-gramatical. Em algum momento de nossa conversa, fomos casualmente levados à imagem gramatical de temporalidade real ou atual de uma escrita historiográfico-terapêutica, tão bem mostrada pela litografia de Escher se vendo na sua esfera espelhada, que ele mesmo nomeou Um autorretrato em um espelho esférico. E este aspecto do ver-se como num autorretrato autorreflexivo, holístico, completo, atualmente infinito e panorâmico de Escher nos mostra uma semelhança de família com o aspecto autorreflexivo e autoterapêutico da apresentação panorâmica segmentada dos fatos em uma escrita terapêutico-historiográfica. A discussão em torno desse aspecto segmentado, descontínuo ou discreto dessa escrita nos levou ao texto de Juliet Floyd que explica esse aspecto por meio de um suposto e irreversível impacto gerado no pensamento de LW pelo aspecto holisticamente lacunar, descontínu e incompleto que passava a assumir o edifício do discurso matemático após Turing, em seu artigo relativo aos números computáveis, ter produzido um novo autorretrato da arquitetura desse edifício, cujas ruínas já haviam sido mostradas pelo teorema da incompletude de Gödel. Gödel havia mostrado que se o retrato panorâmico da matemática 'napoleonicamente' estampado na École Polytechnique ${ }^{188}$ da "Paris capital do século 19" - outrora orgulhoso de sua imponência, onipotência e unicidade

\footnotetext{
188 A Escola Politécnica de Paris - a mais célebre e prestigiosa escola de engenharia francesa - foi fundada em 11 de março de 1794 por Napoleão Bonaparte e pelos matemáticos-engenheiros Gaspard Monge (1746-1818) e Lazare Carnot. Inicialmente pensada como uma proposta de desenho de plantas de fortificações no contexto da engenharia militar, Monge inventou a geometria descritiva, um tipo específico de representação visual plana de um objeto tridimensional que dá visibilidade completa a todos os detalhes do objeto, inacessíveis pelo olhar em perspectiva cônica dos pintores que pode representar o objeto em várias - porém, sempre únicas - perspectivas. Esse tipo de descrição visual plana e completa, porém, segmentada em três vistas (planta, elevação e lateral) de um objeto proporcionada pela geometria descritiva fornece até hoje a base para a arquitetura e desenho técnico industrial. Misto de matemático, físico, engenheiro militar, político e poeta, Lazare Carnot (1753-1823) é mais geralmente conhecido como o organizador da vitória das guerras revolucionárias francesas. Tendo inicialmente cursado engenharia e tendo também projetado e acompanhado a construção de uma casa para uma de suas irmãs, é claro que LW estudou a geometria descritiva, sendo, portanto, tentador levantar a hipótese de uma conexão direta, porém com propósitos completamente distintos, entre a apresentação visual panorâmica de um objeto proporcionada pelo método descritivo segmentado de Monge e apresentação panorâmica das conexões entre imagens proporcionada pelo método terapêutico-gramatical de Wittgenstein, conexões estas descritas através de sua escrita segmentada.
} 
indestrutíveis -, se desejasse continuar a ver-se não contraditório, deveria, necessariamente, mostrar-se incompleto. Investigando a fisiognomia em processo de fragmentação desse retrato gödeliano do edifício estruturalmente abalado da matemática, Turing acabou estampando ainda mais as suas ruínas ao dar visibilidade ao fato de que não seria possível manter a fidelidade panorâmico-fisiognômica desse retrato tentando-se costurar morfologicamente, com um único e mesmo fio lógico, o conjunto de seus de seus fragmentos-colônias, dado que, cada um deles - libertando-se do todo totalitário colonizador que reprimia a manifestação da natureza eletiva das afinidades que poderiam se revelar entre os fragmentos colonizados, e tentando, a todo custo, mantê-los evolutivamente conectados em nome e glória de um projeto civilizatório europeu-padrão-global - poderia decidir proclamar a sua independência, decidir assumir uma fisiognomia própria, caso pudesse mostrar-se um jogo de linguagem autônomo, consistente, completo e decidível. A fisiognomia turinguiana dessa nova matemática descolonizada e desconstruida que se constrói sobre as ruínas da matemática-Paris capital do século 19 espelha e é espelhada pela fisiognomia arquitetônica da nova cidade da linguagem de LW. O 'general' Bourbakiki ${ }^{189}$ continua tentando, até hoje, resgatar os dias de luzes e glória daquela matemática-Paris, assentando os seus escombros sobre um alicerce-fundamento que se vê gramáticaestruturalista-cimento-seguro capaz de manter invariante a fisiognomia arquitetônicofantasmatórica daquela cidade antiga. Ignorando (intencionalmente?) esse projeto arquitetônico restaurador da velha ordem bélico-imperialista napoleônica, a cidade wittgensteiniana da linguagem, semelhantemente ao autorretrato de Escher em sua esfera espelhada - imprimindo-lhe, porém, movimento e dinamicidade -, nos dá a ver panoramicamente e em tempo real, a multiplicidade cinemática - nem mais evolutivo-linear; nem mais cíclico-evolutiva; nem mais evolutivo-dialética; nem mais estruturalista, mantenedora de um fio fisiognômico invariante - da diversidade viva, vital e interativa de formas de vida em suas metamorfoses internas singulares, e não mais edificações formais, formalistas, logicistas e petrificadas da ossatura estrutural de uma cidade fantasma a produzir e estimular o consumo

\footnotetext{
189 A matemática produzida em nome e benefício do projeto colonizador europeu alcançou o seu apogeu na França revolucionária do século XVIII. Porém, ao longo do século XIX, os franceses foram perdendo essa hegemonia para uma nova matemática morfológico-estruturalista que estava sendo produzida, sobretudo, na Alemanha. De acordo com Miguel (2006, p. 7-8), "o movimento bourbakista nasceu na década de 1930, a partir de um 'ato de declaração de guerra' do fictício general grego Nicolas Bourbaki ao estado de subdesenvolvimento em que se encontrava o ensino da matemática acadêmica francesa. Em um artigo denominado $A$ tomada de consciência bourbakista, André Revuz caracteriza do seguinte modo essa reviravolta do ensino acadêmico da matemática na França, no segundo terço do século XX: “O ambiente no qual se inseria o ensino era caracterizado por um provincianismo satisfeito consigo mesmo, e por um individualismo exacerbado, combinado com amadorismo evidente. $O$ que fez, então, Bourbaki? Acatou rigorosamente o contrário dessa atitude. [...] Enquanto grupo, Bourbaki não era um grupo de pesquisa. Seu mérito foi o de ter difundido uma síntese maduramente refletida de resultados que não eram os seus e de ter sido um vulgarizador sem concessão, ao nível mais elevado. O que vulgarizava, não foram somente teorias que eram negligenciadas na França, mas também uma concep̣cão dinâmica da matemática, a despeito da aparência rígida de sua redação" (REVUZ, 1996, p. 73). Essa atualizada vulgata dinâmica e rígida de alto nível foi vista por alguns matemáticos acadêmicos e acadêmicos não-matemáticos da década de 1950 como a mais adequada para se preparar a nova comunidade bélica estadunidense e suas aliadas na Europa, nas Américas e na África. Seria em nome dela que os currículos escolares de todos os níveis, em quase todo o mundo, deveriam passar a se orientar. A nova forma da mentalidade bélica se insinuar na educação matemática acadêmica e escolar não era mais explícita, como convinha a uma concepção fria da guerra fria que mantinha em comum com todas as guerras quentes apenas a sua estrutura. Mera questão de isomorfismo". Esse dinamismo da concepção bourbakista da matemática a que se refere Revuz pode ser melhor caracterizado como um dinamismo da forma, isto é, um metamorfismo à busca não propriamente de semelhanças de família, mas de invariantes em relação a diferentes conjuntos definidos de regras orientadoras das transformações a que foram submetidas determinadas formas, uma réplica, a rigor, da matemática que já vinha sendo desenvolvida por Félix Klein, na Alemanha. O Programa desta nova perspectiva de apresentação holística, formalista e estruturalista da matemática foi didaticamente apresentado pelo grupo Bourbaki no artigo intitulado $A$ arquitetura das matemáticas.
} 
de seus falsos-brilhantes. De modo que, ao mesmo tempo em que Turing se viu no espelho de LW, LW também se viu no espelho de Turing. Orientado, porém, pelo obsessivo desejo de elevar a máquina à altura do humano, o que o olho gramatical de Turing viu no espelho do olho gramatical de LW foi a metamorfose não evolutiva, mas não casual, da forma-fragmentoabstrata isolada, ignorando as totalidades fragmentadas das quais ela pode articipar e com as quais dialeticamente interage. Por sua vez, orientado pelo desejo terapêutico de apresentar panoramicamente como o olho humano olha e significa mediante o estabelecimento de conexões analógicas entre aspectos do que lhe é dado a ver nos jogos de linguagem entretecidos em diferentes formas de vida, o que o olho gramatical de LW viu no espelho do olho gramatical de Turing foi a metamorfose holística casual, não evolutiva e interativa de formas de vida entre si e com totalidades fragmentadas e também casualmente mutantes que estas formas de vida constituem e com as quais dialeticamente interagem.

ORG 2 - Já eu, penso que a imagem da fisiognomia de uma bistoriografia terapêutica que esta sessão de (auto)terapia nos deu a ver nos leva a vê-la como uma totalidade lacunar aberta que não é uma totalidade sistêmica, holística, atomística ou monadística; como um conjunto de fragmentos que não são ruínas e nem partes de um mesmo todo-edifício; como uma narrativa repleta de lacunas ou silêncios que não são abismos, contrassensos ou semsentidos que reivindiquem completamento; como um conjunto de conexões casuais que não são determinismos ou indeterminações; como um jogo de rastros que conecta efeitos e afetos sem causas ou explicações; como paisagem mutante avistada por pássaro migrante, errante entre um não-lugar de partida e um não-lugar de chegada; como uma narrativa lacunar que é reiteradamente continuada, retificada, deletada, retomada, ressignificada..., após ter-se suposto terminada; como uma fisiognomia em movimento sempre perdendo e ganhando outras fisiognomias; enfim, como a fisiognomia da cidade da linguagem de LW.

$\mathbf{F M}^{190}$ - Não pense! Clique na imagem ou no link abaixo e VEJA!

(https://youtu.be/6jLt-gusYKA)

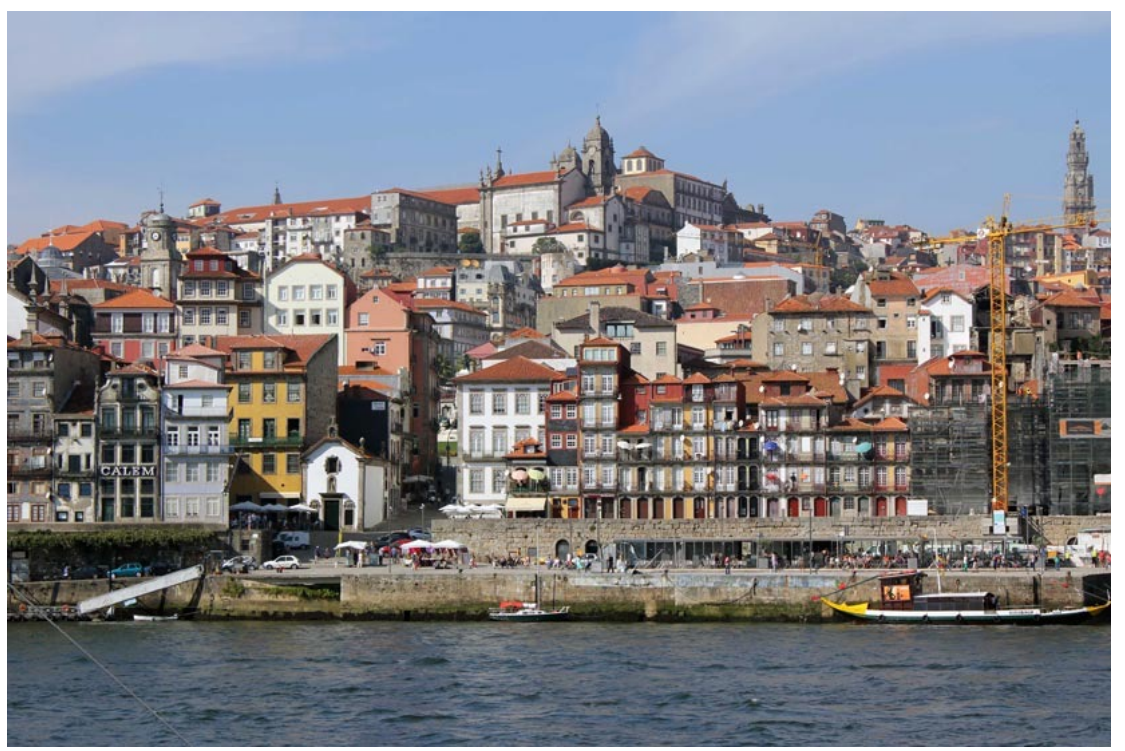

${ }^{190}$ FM são as iniciais do nome do aplicativo "Face Morph" utilizado para se produzir a fisiognomia metamórfica de uma cidade antiga, no caso, a cidade do Porto em Portugal. Acesso foto: (https://www.hotel-america.net/fotos.php). 
ORG 3 - Tendo em vista que, sob a perspectiva de uma historiografia terapêutica são acasos que tecem os tapetes das formas vida, teria sido, então, também por acaso que teríamos nos proposto a levar ao divã terapêutico wittgensteiniano o problema da fisiognomia de uma historiografia terapêutica, com base no experimento coletivo prévio de produção de uma historiografia de acasos?

$\mathbf{F P}^{191}$ - Ah, quem escreverá a história do que poderia ter sido?

Será essa, se alguém a escrever, a verdadeira história da humanidade. [...]

Sou quem falhei ser.

Somos todos quem nos supusemos.

A nossa realidade é o que não conseguimos nunca.

Que é daquela nossa verdade - o sonho à janela da infância?

Que é daquela nossa certeza — o propósito à mesa de depois?

Medito, a cabeça curvada contra as mãos sobrepostas

sobre o parapeito alto da janela de sacada,

sentado de lado numa cadeira, depois de jantar.

Que é da minha realidade, que só tenho a vida?

que é de mim, que sou só quem existo?

Quantos Césares fui!

$\mathbf{L W}^{192}$ - "Acredito que poderia sintetizar meu posicionamento em relação à filosofia quando digo: na verdade, deve-se escrever filosofia apenas como se escreve um poema".

ORG 2 - Teria sido? Será? É provável? Não! É só o imprevisível, o acaso! Mas não dispomos de uma gramática que nos permita preencher esta lacuna, que nos permita expressar com sentido este on aquele desejo de qualquer outrora passado on futuro, esta on aquela recordação... Silêncios, pausas e lacunas há! Mas não gramáticas do silêncio, da pausa, da lacuna! O limite de nossos sonhos e desejos de quaisquer outroras é também o limite de nossos jogos de linguagem. Não há uma gramática da história... assim como não há uma gramática do acaso! Histórias e acasos são agramaticais!

ORG 3 - Mas um agramatical é ainda um jogo de linguagem. Nomeamos e falamos de acasos em nossos jogos de linguagem. Não foi o que propomos e nos propomos a fazer nesta obra, nesta nossa historiografia terapêutica de acasos?

ORG 2 - No momento em que fazemos acasos e temporalidades participarem de nossos jogos de linguagem, nós os gramaticalizamos, gramaticalizamos agramaticais. Gramaticalizamos temporalidades, espacialidades, acasos nomeando-os recordações ou predições. Mas, tudo pulsa e vive transformado em cada presente. Recordar ou predizer

\footnotetext{
191 Poema de 07 de dezembro de 1933, intitulado “Pecado original' (PESSOA, 1959), escrito pelo heterônimo Álvaro Caiero do poeta português Fernando Pessoa, grifo nosso. Disponível em: (http://arquivopessoa.net/textos/81). Acesso em 18 de novembro de 2020.

192 (LW, 1998, p. 29).
} 
são fraudes, ilusionismos, fake news necessários que nos fazem manter vivos, lutar, esperar, desejar, sonhar, acreditar... ilusionismos que acalmam a filosofia. E também a história...

WB $\mathbf{B}^{193}$ - "Articular historicamente o passado não significa conhecê-lo "como ele de fato foi”. Significa apropriar-se de uma reminiscência, tal como ela relampeja no momento de um perigo. [...] Pois o Messias não vem apenas como salvador; ele vem também como o vencedor do Anticristo. $\mathrm{O}$ dom de despertar no passado as centelhas da esperança é privilégio exclusivo do historiador convencido de que também os mortos não estarão em segurança se o inimigo vencer. E esse inimigo não tem cessado de vencer."

$\mathbf{L W}^{194}$ - "O trabalho do filósofo é um acumular de recordações para uma finalidade determinada".

$\mathbf{B B}^{195}$ - "Pensa na escuridão e no grande frio que reinam nesse vale, onde soam lamentos".

LW $\mathbf{W}^{196}$ - "Quando filosofas, tens de descer ao caos primordial e sentires-te como em casa".

ORGS - O que sabemos é que se a fisiognomia segmentada, lacunar, não evolutiva e casual de uma historiografia terapêutica se assemelha às fisiognomias igualmente segmentadas, lacunares, não evolutivas e casuais dos tapetes das formas de vida, deixa de ser casual que o que será dado a ver aos leitores, nos capítulos que se seguem, seja um álbum terapêutico de retratos de acasos encenados em diferentes formas de vida que, quando sobrepostos, lhes darão a ver uma fisiognomia possivel de uma historiografia terapêutica de acasos.

\section{Referências}

AMBRIZZI, Miguel L. O olhar distante e o próximo - a produção dos artistasviajantes. 19\&20, Rio de Janeiro, v. VI, n. 1, jan./mar. 2011. Disponível em: <http://www.dezenovevinte.net/artistas/viajantes_mla2.htm>.

ARTISTAS Viajantes. In: ENCICLOPÉDIA Itaú Cultural de Arte e Cultura Brasileiras. São Paulo: Itaú Cultural, 2021. Disponível em:

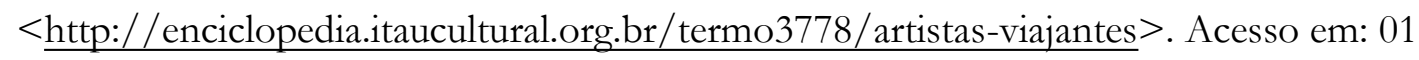
Jan. 2021. Verbete da Enciclopédia. ISBN: 978-85-7979-060-7

BENJAMIN, Walter. Magia e técnica, arte e política: ensaios sobre literatura e história da cultura. Obras escolhidas, volume I. Tradução por Sérgio Paulo Rouanet. Prefácio por Jeanne Marie Gagnebin. 3. ed. São Paulo: Editora Brasiliense, 1987.

\footnotetext{
193 Ponto de vista de Walter Benjamin expresso em seu texto "O conceito da bistória” (BENJAMIN, 1987, p. 224-225, grifo nosso).

194 (LW, IF-127, grifo nosso).

195 Aforismo do dramaturgo alemão Bertold Brecht (1898-1956) extraído de sua peça teatral-operística $A$ ópera dos três vinténs, com música do compositor alemão Kurt Weill (1900-1950).

196 (LW, 2000, p. 98, aforismo de 1948).
} 
. Passagens. Belo Horizonte: Editora UFMG; São Paulo: Imprensa Oficial do Estado de São Paulo, 2009.

CASSIRER, Ernst. The mith of the State. Chelsea, Michigan: Bookcrafters, Inc., 1946.

CONDÉ, Mauro Lúcio. L. As teias da razão: Wittgenstein e a crise da racionalidade moderna. Belo Horizonte: Argvmentvm, 2004.

DAVIS, Philip J.; HERSH, Reuben. A experiência matemática. Tradução de João Bosco Pitombeira. Rio de Janeiro: Francisco Alves, 1985.

DIDEROT, Denis. Continuação do diálogo. In: DIDEROT, D. Textos

escolhidos/Diderot. Traduções e notas de Marilena de Souza Chaú e Jacob Guinsburg. São Paulo: Abril Cultural, (Os pensadores), 1979.

DIDEROT, Denis; D’ALEMBERT, Jean le Rond. Enciclopédia, ou Dicionário razoado das ciências, das artes e dos ofícios. Organização de Pedro Paulo Pimenta e Maria das Graças de Souza. Tradução de Fúlvia Moretto e Maria das Graças de Souza. 1. ed. São Paulo: Editora Unesp, 2015.

DOYLE, Arthur C. Um estudo em vermelho. Rio de Janeiro: Zahar, 2009.

EILENBERGER, Wolfram. Tempo de mágicos: a grande década da filosofia: 19191929. Tradução Claudia Abeling. São Paulo: Todavia, 2019.

FLÓREZ, Alfonso. Wittgenstein y las máquinas de Turing. In: FLÓREZ, Alfonso; HOLGÍN, Magdalena; MELÉNDEZ, Raúl. Del espejo a las herramientas. Ensayos sobre el pensamiento de Wittgenstein. Bogotá: Siglo del Hombre Editores, 2003. p. 199217.

FLOYD, Juliet. Chains of Life: Turing, Lebensform, and the Emergence of Wittgenstein's Later Style. Nordic Wittgenstein Review, Bergen (Noruega), v. 5, n. 2, p. 7-89, dez. 2016.

FRAZER, James. G. The Golden Bough. New York: Macmillan/St. Martin's Press, 1966.

. O ramo de ouro. Versão ilustrada. Prefácio: Professor Darcy Ribeiro.

Tradução: Waltensir Dutra. São Paulo: Zahar Editores, 1982.

GALTON, Francis. Composite Portraits. London: Harrison and Sons, St. Martin's Lane, 1878.

. Essays in Eugenics. London: The Eugenics Education Society, 1909. 
Finger Prints: The Classic 1892 Treatise. New York: Dover Publications, 2005.

GEBAUER, Gunter. O pensamento antropológico de Wittgenstein. Tradução Milton Camargo Mota. São Paulo: Edições Loyola, 2013.

GINZBURG, Carlo. O fio e os rastros: verdadeiro, falso, fictício. Tradução de Rosa Freire d'Aguiar e Eduardo Brandão. São Paulo: Companhia das Letra, 2007.

GLOCK, Hans-Johann. Dicionário Wittgenstein. Trad. Helena Martins. Rio de Janeiro: Zahar, 1998.

GOETHE, Johann V. V. A metamorfose das plantas. Tradução Friedhelm Zimpel e Lavínia Viotti. 3. ed. São Paulo: Antroposófica, 1997.

. As afinidades eletivas. Tradução por Tercio Redondo. Introdução por R. J. Hollingdale São Paulo: Penguin Companhia das Letras, 1971.

. A doutrina das cores. Apresentação, seleção e tradução de Marco Giannotti. São Paulo: Nova Alexandria, 1993.

GOMES, Augutso P. M. B. Decadência e História em Oswald Spengler. In: XXVI SIMPÓSIO NACIONAL DE HISÓRIA - ANPUH, 2011, São Paulo. Anais... São Paulo: , 2011. p. 1-16.

GUERRA, Claudia. B. As cores em Wittgenstein: da fenomenologia aos jogos de linguagens e à fotografia digital. LOGEION: Filosofia da informação, Rio de Janeiro, v. 2, n. 2, p. 66-79, mar./ set. 2016.

HARTOG, François Crer em História. Belo Horizonte: Autêntica Editora, 2017.

HEATON, John M. The Talking Cure: Wittgenstein's Therapeutic Method for Psychotherapy. New York: Palgrave Macmillan, 2010.

HLAVÁC, Václav Mathematical morphology. s/d. Disponível em: $<$ http://people.ciirc.cvut.cz/ hlavac/TeachPresEn/11ImageProc/713MatMorpholBinEn.pdf>. Acesso em 05 nov. 2020.

HOLGUÍN, Magdalena. El método en Wittgenstein. In: FLÓREZ, A.; HOLGÍN, M.; MELÉNDEZ, R. (Orgs.). Del espejo a las herramientas. Ensayos sobre el pensamiento de Wittgenstein. Bogotá: Siglo del Hombre Editores, 2003. p. 125-140.

JARMAN, Derek. Chroma: a book of color. Minneapolis: University of Minnesota Press, 2010. 
KLEIN, Felix. O Programa de Erlangen de Felix Klein: considerações comparativas sobre as pesquisas geométricas modernas. Tradução e Comentários de Normando Celso Fernandes. São Paulo: IFUSP, 1984.

LÊNIN, Vladimir I. Materialismo e empiriocriticismo. Lisboa: Edições Progresso, 1982.

LIMA, Alice Santana. Spix, Martius e o legado histórico-científico-ficcional das viagens, 2019. Acessível no seguinte site,

<https://blog.bbm.usp.br/2019/spix-martius-e-o- legado-historico-cientifico-ficcionaldas-viagens/>. Acesso em: 02 dez. 2020:

LO PIPARO, Franco. Il professor Gramsci e Wittgenstein: Il linguaggio e il potere. Roma: Donzelli Editore, 2014.

MARX, Karl. Miséria da filosofia. São Paulo: Grijalbo, 1976.

MALCOLM, Norman. Ludwig Wittgenstein: A memoir, with a Biographical Sketch by G. H. von Wright, second edition with Wittgenstein's letters to Malcolm. Oxford: Clarendon Press, 2001.

MIGUEL, Antonio. Pesquisa em Educação Matemática e mentalidade bélica. Bolema: Boletim de Educação Matemática, Rio Claro, ano 19, n. 25, p. 1-16, fev. 2006.

. Escher, espaços curvos e corvos: sobrepondo jogos de linguagem visual e verbal. In: FARIA, A. L. G.; MELLO, S. A. (org.) Territórios da Infância: linguagens, tempos e relações para uma pedagogia para as crianças pequenas. Araraquara: Junqueira \& Marin Editores, 2007. p. 137-168.

. Infâncias e pós-colonialismo. Educação e Sociedade, Campinas, v. 35, n. 128, p. 629-996, jul./set., 2014.

. Uma encenação terapêutica da terapia wittgensteiniana na condução de pesquisas historiográficas. Revista de História da Educação Matemática HISTEMAT, São Paulo, ano 1, n. 1, set-dez 2015, p. 203-255.

. Um jogo memorialista de linguagem: um teatro de vozes. Campinas: FEUNICAMP, 2016a. Disponível em: (http://www.bibliotecadigital.unicamp.br/ document/?code=62532\&opt=4). Acesso em 05 de novembro de 2020.

. Entre jogos de luzes e de sombras: uma agenda contemporânea para a educação matemática brasileira. Perspectivas da Educação Matemática, Campo Grande, v. 9, n. 20, p. 323-365, dez. 2016b. 
Historiografia e terapia na cidade da linguagem de Wittgenstein. Bolema, Rio Claro, v. 30, n. 55, p. 368-389, ago. 2016c.

O cravo de Diderot e as novas políticas educacionais: um diálogo com as luzes em uma nova época de trevas. In: OLIVEIRA, A. M. P.; ORTIGÃO, M. I. R. (Org.). Abordagens teóricas e metodológicas nas pesquisas em Educação Matemática. Livro Eletrônico. Brasilia: Sociedade Brasileira de Educação Matemática, 2018. p. 298320.

MIGUEL, Antonio; TAMAYO, Carolina. Wittgenstein, Terapia e Educação Escolar Decolonial. Educação \& Realidade, Porto Alegre, v. 45, n. 3, out. 2020, p. 1-40.

MIGUEL, Antonio.; VIANNA, Carlos R. Vírus vêm em vão: uma alegoria da panescola que (não) virá. Revista Latinoamericana de Etnomatemática, v. 13, n. 1, p. 628, ago. 2020.

NANJUNDIAH, Vidyanand. Alan Turing and The Chemical Basis of Morphogenesis. In: SEKIMURA, T.; NOJI, S.; UENO, N.; MAINI, P. K. (eds.) Morphogenesis and Pattern Formation in Biological systems. Tokyo: Springer-Verlag, 2002. p. 33-44.

NEDO, Michael. Wittgenstein and Cambridge Family Resemblances. 2011.

Disponível em: < http://www. editor.net/BWS/docs/ClareHallCatalogueNew.pdf $>$. Acesso em: 05 nov. 2020.

NIETZSCHE, Friedrich W. Além do bem e do mal ou prelúdio de uma filosofia do futuro. Tradução de Márcio Pugliesi. Curitiba (PR): Hemus S.A., 2001.

PESSOA, Fernando. Mensagem. Lisboa: Edições Ática,1959.

PLEASANTS, Nigel. Wittgenstein and the idea of a critical social theory: a critique of Giddens, Habermas and Bhaskar. London, New York: Routledge, 1999.

REVUZ, Andre. La prise de conscience bourbakiste. In: BELHOSTE, B.; GISPERT, H.; HULIN, N. (Org.). Les sciences au Lycée: un siècle de reformes des mathématiques et de la Physique em France et à l'étranger. Paris: Librairie Vuibert, 1996. p. 69-76.

RIBEIRO, Monike G. A Missão Austríaca no Brasil e as aquarelas do pintor Thomas Ender no século XIX. 19\&20, Rio de Janeiro, vol II, n. 2, abr. 2007. Disponível em: (http://www.dezenovevinte.net/artistas/thomas_ender.htm).

RIBEIRO, Naiara. dos S. D. A morfologia histórica de Johan Huizinga e o caráter pragmático do passado. História da historiografia, Rio de Janeiro/Ouro Preto, n. 04, jun. 2010. p. 234-254. 
SALLES, João C. Percepção e Cor: Nota sobre o octaedro das cores em Wittgenstein. doispontos, Curitiba, v. 9, n. 2, p. 123-133, out. 2012.

SEKULA, Allan. The body and the archive. In: BOLTON, R. (Ed.). The contest of meaning: critical histories of photography. London: MIT Press, 1992.

SILVA, Marcos. Wittgenstein, cores e sistemas: aspectos lógico-notacionais do colapso do Tractatus. ANALYTICA, Rio de Janeiro, v. 15, n. 2, ago-dez 2011, p. 229-264.

SILVA, José P. SOLETRAS, Ano VI, N 11. São Gonçalo: UERJ, jan./jun. 2006.

SOARES, Franciane M. da S. A imagem também ensina: um retrato da economia colonial brasileira através das imagens de Frans Post. Monografia de Graduação. Universidade Federal do Rio Grande do Norte. Centro de Ciências Humanas, Letras e Artes. Programa de Graduação em História. Natal (RN), 2014.

SOUTO, Iaci P. Prometeu: Fragmento Dramático, de Goethe. Cadernos de Literatura em Tradução, São Paulo, n. 11, 2010, p. 203-241.

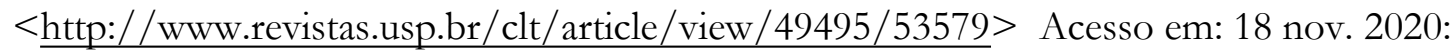

SPENGLER, Oswald. O homem e a técnica: contribuição a uma filosofia da vida. Tradução de Erico Verissimo. Porto Alegre: Edições Meridiano, 1941.

TAYLOR, Sue. Hans Bellmer: the anatomy of anxiety. London: The MIT Press, 2000.

TOLEDO, Elpídio de. O método de Goethe de observação da natureza. Diálogos: Revista de Estudos Culturais e da Contemporaneidade, Garanhuns (PE), v. 1, n. 2, agodez 2007, p. 32-40. Disponível em:

<http://www.revistadialogos.com.br/Dialogos_2/Dial_2_Elpidio.pdf.> Acesso em 18 nov. 2020:

VEIGA-NETO, Alfredo; LOPES, Maura C. Identidade, cultura e semelhanças de família: as contribuições da virada linguística. In: BIZARRO, R. (org.). Eu e o outro: Estudos Multidisciplinares sobre Identidade(s), Diversidade(s) e Práticas Interculturais. Porto: Areal, 2007, p. 19- 35.

VELOSO, Eduardo. Geometria: temas actuais: materiais para professores. Lisboa: Ministério da Educação. Instituto de Inovação Educacional, 2000.

WITTGENSTEIN, Ludwig. Investigações filosóficas. Trad. José Carlos Bruni. São Paulo: Abril Cultural, 1979.

Cultura e valor. Trad. Jorge Mendes. Lisboa: Edições 70, 2000. 
. Observações filosóficas. São Paulo: Edições Loyola, 2005a.

.Philosophische Untersuchungen/Philosophical Investigations.

Translated by Gertrude E.M. Anscombe, Peter M.S. Hacker, and Joachim Schulte. Rev. 4th ed./by P.M.S. Hacker and Joachim Schulte.UK: Wiley-Blackwell Publishing Ltd, 2009a.

Anotações sobre as cores - Bemerkungen über die Farben. Apresentação, estabelecimento do texto, tradução e notas por João Carlos Salles Pires da Silva. Campinas: Editora da Unicamp, 2009b.

Tractatus Logico-Philosophicus. Tradução, apresentação e estudo introdutório de Luiz Henrique Lopes dos Santos; [Introdução de Bertrand Russell]. São Paulo: Editora da Universidade de São Paulo, 2010.

. Investigações filosóficas/Philosophische untersuchungen. Edição bilingue alemão/português. (João J. R. L. de Almeida, Apontamentos, Tradução e Notas). Wittgenstein Translations, s/d. Disponível em: < http://www.psicanaliseefilosofia.com.br/textos/>. Acesso em: 20 out. 2020:

Bemerkungen über die Grundlagen der Mathematik/Observações sobre os Fundamentos da Matemática. Tradução e Notas de João José R. L. de Almeida. Preprint. s/d. Disponível em: < http://www.psicanaliseefilosofia.com.br/traducao/OFM-PrePrint.pdf).> Acesso em 20 out. 2020 :

Observações sobre o Ramo de Ouro de Frazer. Tradução e notas comentadas por João José R. L. Almeida. Revista Digital Ad Verbum, , v. 2, n. 2, p. 186-231, jul./dez. 2007. Disponível em:

$<\underline{\text { http://www.psicanaliseefilosofia.com.br/adverbum/revistaadverbum.html }>\text { Acesso }}$ em 15 out. 2020 